U.S. Department of the Interior

U.S. Geological Survey

Prepared in cooperation with

The Unified Sewerage Agency of Washington County, Oregon

\title{
Selected Elements and Organic Chemicals in Bed Sediment and Tissue of the Tualatin River Basin, Oregon, 1992-96
}

Water-Resources Investigations Report 99-4107



\title{
U.S. DEPARTMENT OF THE INTERIOR \\ BRUCE BABBITT, Secretary
}

\author{
U.S. GEOLOGICAL SURVEY \\ Charles G. Groat, Director
}

Front cover photographs: Left, Gales Creek near Glenwood is in the Coast Range Mountains and serves as a reference site for the Tualatin River Basin; upper right, bed sediment is composited before analysis; lower right, a Torrent sculpin is collected for tissue analysis.

All photographs by Dennis A. Wentz, U.S. Geological Survey
For additional information contact:
District Chief
U.S. Geological Survey
10615 S.E. Cherry Blossom Drive
Portland, OR 97216
telephone: (503) 251-3200
e-mail: info-or@usgs.gov

\author{
Copies of this report can be purchased from: \\ U.S. Geological Survey \\ Information Services \\ Box 25286 Federal Center \\ Denver, CO 80225 \\ telephone: (303) 202-4210 \\ e-mail: infoservices@usgs.gov
}

Information is also available on the Internet via the World Wide Web.

The Oregon District Home Page is: http://oregon.usgs.gov/

The use of firm, trade, and brand names in this report is for identification purposes only and does not constitute endorsement by the U.S. Government

\begin{tabular}{|c|c|c|c|c|c|}
\hline \multicolumn{3}{|c|}{ CONCENTRATION UNITS } & \multicolumn{3}{|c|}{ LENGTH UNITS } \\
\hline Abbreviation & Unit & $\begin{array}{l}\text { Equivalent } \\
\text { dimensionless unit }\end{array}$ & Abbreviation & Unit & Definition \\
\hline$\%$ & percent & parts per hundred & $\mathrm{mm}$ & millimeter & $10^{-3}$ meter \\
\hline $\mathrm{mg} / \mathrm{g}$ & milligram per gram & parts per thousand & $\mu \mathrm{m}$ & micrometer & $10^{-6}$ meter \\
\hline$\mu \mathrm{g} / \mathrm{g}$ & microgram per gram & parts per million & & & \\
\hline $\mathrm{ng} / \mathrm{g}$ & nanogram per gram & parts per trillion & & & \\
\hline
\end{tabular}




\section{U.S. Department of the Interior \\ U.S. Geological Survey}

\section{Selected Elements and Organic Chemicals in Bed Sediment and Fish Tissue of the Tualatin River Basin, Oregon, 1992-96}

BY BERNADINE A. BONN

Water-Resources Investigations Report 99-4107

Prepared in cooperation with

THE UNIFIED SEWERAGE AGENCY OF WASHINGTON COUNTY, OREGON

Portland, Oregon: 1999

\section{CONTENTS}

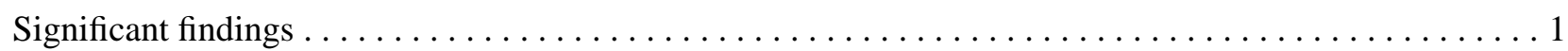

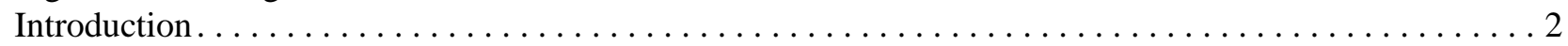

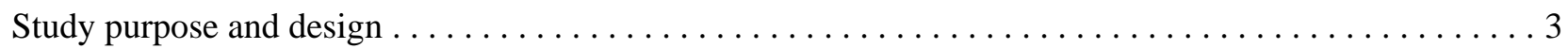

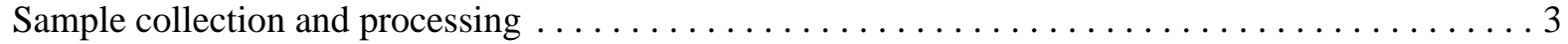

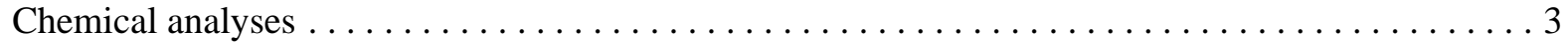

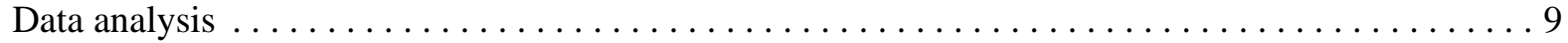

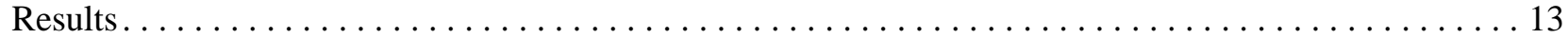







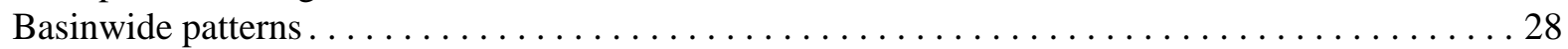

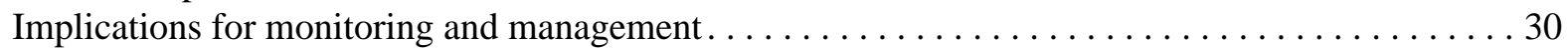

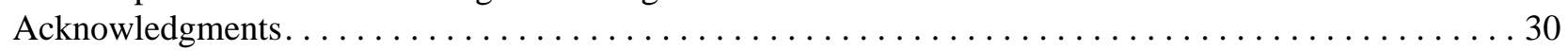

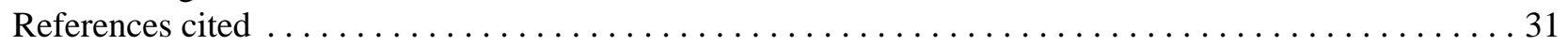

Appendix A. Explanation of statistical comparison of replicate ranges $\ldots \ldots \ldots \ldots \ldots \ldots \ldots \ldots \ldots$

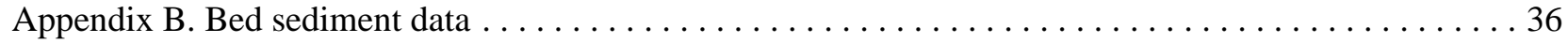

Appendix C. Qualitative description of fish occurrence and abundance $\ldots \ldots \ldots \ldots \ldots \ldots \ldots \ldots \ldots$

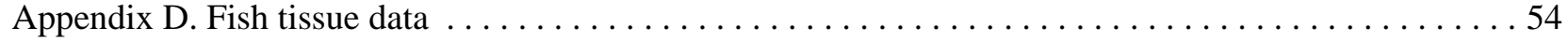





\title{
Selected Elements and Organic Chemicals in Bed Sediment and Fish Tissue of the Tualatin River Basin, Oregon, 1992-96
}

\author{
By Bernadine A. Bonn
}

\section{SIGNIFICANT FINDINGS}

- Concentrations of trace elements in Tualatin Basin sediments and fish tissue, including arsenic, chromium, copper, lead, mercury, nickel, selenium, and zinc, were generally similar to those found in the Willamette Basin and were toward the lower end of the range of national concentrations.

- No exceedances of U.S. Environmental Protection Agency (USEPA) Tier 1 sediment screening values for any trace element were observed in the Tualatin Basin.

- Concentrations of chromium, copper, and nickel exceeded USEPA Tier 2 screening values at all sites in the basin. Copper and nickel concentrations were highest at the background sites and probably were related to basin geology.

- Polyaromatic hydrocarbons (PAHs) were detected more frequently in Tualatin Basin sediment than in either the Willamette Basin or the Nation. The higher frequency of PAH detection in the Tualatin Basin probably occurs because of the large number of urban sites in the basin. When detected, however, PAH concentrations in the Tualatin Basin sediments were similar to those observed elsewhere.

- In general, few organochlorine pesticides were detected in bed sediment or tissue in the Tualatin Basin. Chlordanes and $p, p$ '-DDE were commonly detected in both sediment and fish tissue. Dieldrin was also commonly detected in fish tissue.

- Correlations of concentrations in bed sediment with those in tissue were poor for most elements and weak, at best, for organochlorine compounds. Concentrations of organochlorine compounds in tissue usually exceeded those in bed sediment concentrations by at least tenfold.

- Contamination patterns that were consistent with urban sources-high concentrations of PAHs, lead, and some phthalates-were found at Ash Creek at Greenburg Road, Fanno Creek at Nicol Road, Fanno Creek at Denny Road, and McKay Creek at Hornecker Road.

- High levels of organochlorine pesticides in both sediment and fish tissue were found at two sites in largely residential areas (Fanno Creek at Nicol Road and Fanno Creek at Denny Road). Concentrations of total chlordane, dieldrin, and p,p'-DDE in sediment at these sites exceeded USEPA Tier 2 screening values. Concentrations of total chlordane in fish tissue exceeded both the National Academy of Science/National Academy of Engineering (NAS/NAE) guidelines and the New York State criteria. Organochlorine concentrations were much lower downstream of these sites where the land use changed to light industrial; concentrations of trace elements, however, increased.

- The most contaminated bed sediment found in this study was collected from the most urban site (Beaverton Creek at Cedar Hills Boulevard). USEPA sediment screening values were exceeded for four organochlorine pesticides, six polyaromatic PAHs, two phthalates, $p$-cresol, and eight metals (including arsenic, cadmium, lead, and mercury). Levels of polychlorinated biphenyls in the few fish found at this site exceeded the NAS/ NAE guidelines for fish tissue. 


\section{INTRODUCTION}

A variety of elements and organic compounds have entered the environment as a result of human activities. Such substances find their way to aquatic sediments from direct discharges to waterways, atmospheric emissions, and runoff. Some of these chemicals are known to harm fish or wildlife, either by direct toxicity, by reducing viability, or by limiting reproductive success. In aquatic systems, sediments become the eventual sink for most of these chemicals. Analyzing the sediments provides a first step in a chemical inventory that can lead to an assessment of potential biological impacts (Kennicutt and others, 1994).

Many elements (iron, aluminum, calcium, and others) enter the environment from the natural weathering of rock. Additional amounts of elements have been contributed by human activities such as mining, metals production and processing, fossil fuel combustion, municipal waste incineration, and transportationrelated sources. The environmental presence of some elements, such as lead and mercury, is almost entirely due to human activity. Lead is often associated with the use of leaded gasoline and from the manufacture and disposal of lead storage batteries. Mercury was used historically in a variety of industrial processes and as a pesticide. Nriagu and Pacyna (1998) concluded that human activity is the "most important element in the global biogeochemical cycling of the trace metals."

The number of organic compounds in existence and their total production has more than tripled in the last century. Many of these compounds enter the environment directly as pesticides; others are inadvertently discharged. Some organic compounds have natural sources. Three general classes of organic compounds will be discussed: organochlorine compounds, polyaromatic hydrocarbons, and phthalates.

Almost all organochlorine compounds are manmade. Many are pesticides that were used widely in the 1950s-60s (DDT and chlordanes, for example). Use of most organochlorine pesticides was restricted or banned in the United States in the 1970s-80s. Polychlorinated biphenyls (PCBs) are also organochlorine compounds; they were used for a variety of applications, but most commonly as insulators in electrical transformers and other equipment. In general, organochlorine compounds degrade very slowly in the environment and therefore, are routinely found in environmental samples, despite the fact that they are no longer used in the United States. They are hydropho- bic, that is they do not dissolve readily in water and, in aquatic systems, are almost exclusively associated with sediments or tissue. Because these compounds cause a variety of adverse health effects in wildlife, the U.S. Environmental Protection Agency (USEPA) has listed many as priority pollutants. Organochlorine compounds also have been implicated as endocrine disrupters-chemicals that can interfere with the normal function of hormones.

Polyaromatic hydrocarbons (PAHs) are found in sediments throughout the world (Hites and others, 1980). Their presence is thought to be primarily anthropogenic. PAHs occur naturally in petroleum products and also are produced during combustion. They enter the environment from fuel spills, tar coatings, coal and other fossil fuel usage, road dust, and from the atmospheric deposition of combustion products (Prahl and others, 1984; Wakeham and others, 1980). Urban areas often have high concentrations of PAHs because of transportation-related sources (vehicle exhaust, paving materials, and releases of fuel or oil). Natural sources, such as forest fires, may contribute small amounts of PAHs. Several PAHs are known carcinogens (benzo[ $a]$ pyrene, for example); 16 are listed as USEPA priority pollutants.

Phthalate compounds are often associated with urban areas. They are used in a wide variety of industrial applications and in inks, adhesives, resins, and as plasticizers (chemicals that increase the flexibility of plastics). In aquatic systems, phthalates are found mostly in sediments where they degrade very slowly. Phthalates are thought to be endocrine disrupters; Jobling and others (1995) found that some phthalates were weakly estrogenic. USEPA considers some phthalates to be possible carcinogens.

This report describes the results of a reconnaissance survey of elements and organic compounds found in bed sediment and fish tissue in streams of the Tualatin River Basin. The basin is in northwestern Oregon to the west of the Portland metropolitan area (fig. 1). The Tualatin River flows for about 80 miles, draining an area of about 712 square miles, before it enters the Willamette River. Land use in the basin changes from mostly forested in the headwaters, to mixed forest and agriculture, to predominately urban. The basin supports a growing population of more than 350,000 people, most of whom live in lower parts of the basin. Water quality in the Tualatin River and its tributaries is expected to be affected by the increasing urbanization of the basin. 


\section{STUDY PURPOSE AND DESIGN}

The U.S. Geological Survey (USGS) has worked cooperatively with the Unified Sewerage Agency of Washington County (USA) since 1990 to assess water quality in the Tualatin River Basin. This study, a reconnaissance survey of contaminants in bed sediment and fish tissue in the basin, was done as part of that work. The objectives of this study were to:

- assess the occurrence and magnitude of trace element and selected organic contaminants in streams of the Tualatin River Basin,

- compare contaminant levels found in Tualatin River Basin streams with published guidelines for the protection of aquatic life,

- place the contaminant levels found in the Tualatin River Basin streams in context, regionally and nationally, by comparing them with those found in the Willamette Basin and by the USGS National Water-Quality Assessment (NAWQA) Program,

- compare contaminant concentrations in bed sediment with those in fish tissue, and

- identify contaminant patterns that would help managers make decisions regarding future monitoring and the implementation of pollution prevention and abatement programs.

This study began in 1992 as a survey of contaminants in bed sediment. It was expanded in 1996 to include the analysis of fish tissue. Two more sites were added at that time. In addition, this study was designed to utilize data that had been collected in the basin in 1992-93 by the NAWQA Program.

\section{Sample collection and processing}

Bed sediment samples were collected from 15 sites in the Tualatin Basin; fish tissue samples were collected at 9 sites (fig. 1, table 1). Many of the sampled streams drain largely urban areas that include a mixture of commercial and residential land. Chicken, Dairy, and McKay Creeks are the only sampled streams with appreciable agricultural land in their basins that do not also have significant urban influences. Gales Creek drains mostly forested land and is minimally affected by anthropogenic inputs; it represents background concentrations.

At wadeable sites, the top 1-2 $\mathrm{cm}$ of fine grained sediment was collected with a Teflon scoop. Sediment was removed from several depositional areas within a reach and composited. At nonwadeable sites (Tualatin River above Dairy Creek and Tualatin River at Elsner Road), the same approach was used, except that the method was applied to sediment sections that had been obtained using an Eckman dredge. In all cases, about $8 \mathrm{~L}$ of wet sediment was collected from each site. The reach length sampled varied among sites from about 40 to $1,200 \mathrm{ft}$. Sediment samples destined for organics analysis were sieved through a 2-mm stainless steel sieve to remove twigs, pebbles, and other debris. Samples destined for elemental analysis were sieved through a $63 \mu \mathrm{m}$ nylon screen to remove the sand fraction as well as larger debris. Because trace elements are not expected to significantly sorb to the sand-sized fraction, sieving at $63 \mu \mathrm{m}$ effectively "normalizes" samples to the size fraction having the highest concentrations of trace elements. Samples were kept at $4{ }^{\circ} \mathrm{C}$ until analysis. The sediment collection and preparation method is described in detail by Shelton and Capel (1994).

Fish were collected by electrofishing and then euthanized by a sharp blow to the head. Each sample consisted of 4-20 whole fish. All fish were sculpin.

Samples destined for elemental analysis were placed in resealable polyethylene freezer bags; samples destined for organics analysis were wrapped in aluminum foil. All samples were frozen until analysis. The fish were thawed, homogenized, and subsampled by the USGS National Water Quality Laboratory (Arvada, Colorado).

\section{Chemical analyses}

Sediment samples were analyzed for major and minor elements, organochlorine pesticides, pesticide metabolites, PCBs, and semivolatile organic compounds such as PAHs, phthalates, and phenols. Fish tissue samples were analyzed for major and minor elements, organochlorine pesticides, pesticide metabolites, and PCBs. The chemical analyses and analytical methods are summarized in table 2. In addition, for sediment samples, organic carbon content and fraction of grain size less than $63 \mu \mathrm{m}$ were determined; for fish samples, lipid content and moisture content were determined. All analyses were performed by the USGS. Elemental analyses of sediment were done by the Geologic Division Laboratory (Lakewood, Colorado); sediment size fraction analyses were done by the laboratory at the Cascades Volcano Observatory (Vancouver, Washington); all other analyses were done by the National Water Quality Laboratory. 
Censored semiquantitative data- Nondetection of an analyte in a sample does not indicate that the concentration of the analyte in the sample equalled zero. The smaller the concentration of analyte in a sample, the greater the chance that it will not be detected even if it is present. Different types of statistics were used to communicate the analytical limits of different methods.

A minimum reporting level (MRL) was used for elements, organochlorine pesticides, and PCBs. Data for these analytes are censored at the MRL; that is, con- centrations less than the MRL are reported as nondetections. When the concentration is greater than or equal to the MRL, the sample is assumed to be reliably different from a blank sample. When the analyte is not detected in the sample, the concentration is assumed to be less than the MRL. MRLs are based on a variety of factors, including method performance and analyst judgement.

A method detection limit (MDL) was used for semivolatile compounds, such as PAHs, phthalates, and phenols. Unlike the MRL, the MDL does not censor

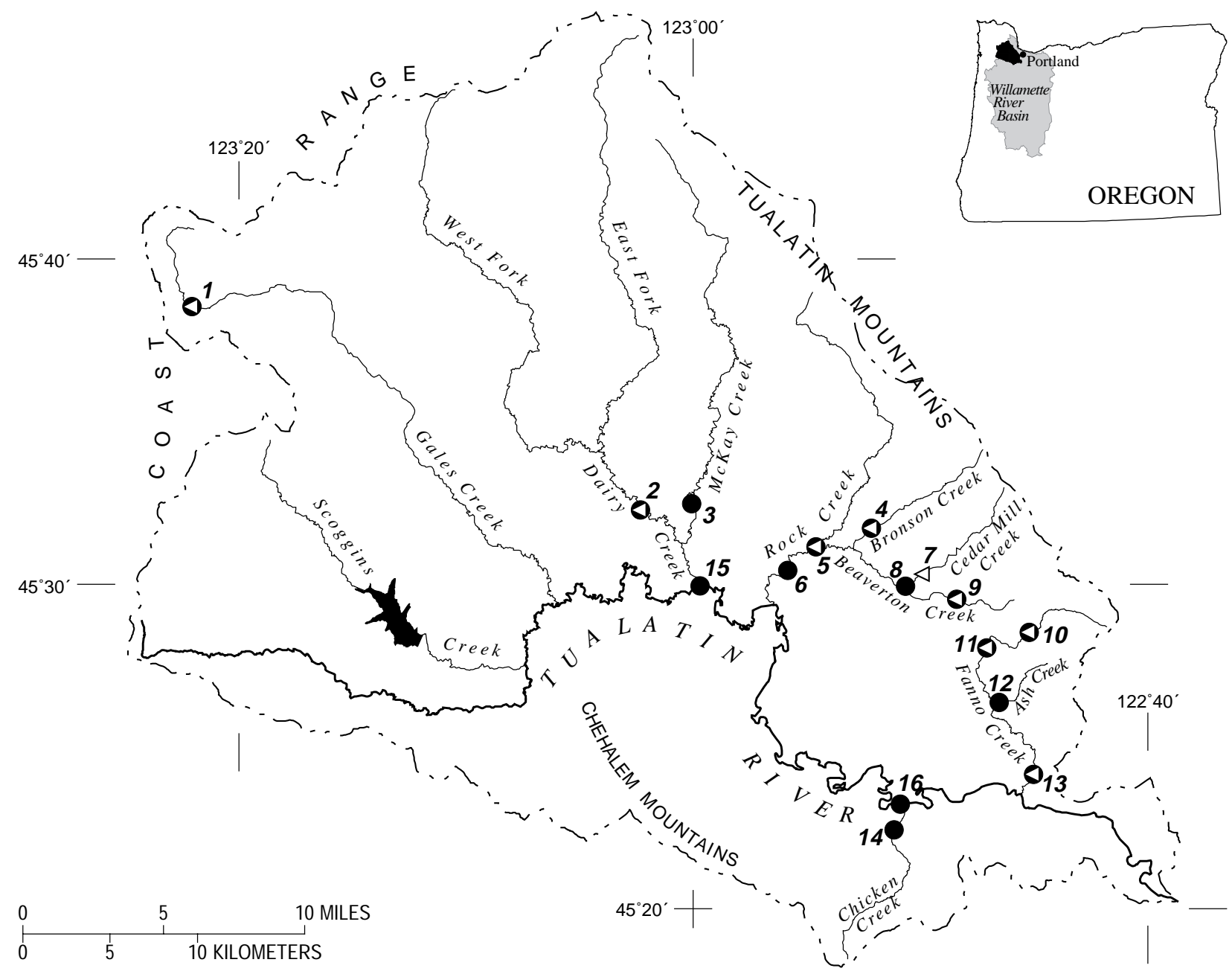

Figure 1. Map of Tualatin River Basin with locations of sampling sites. Sample types are $\bullet$ bed sediment, $\triangleleft$ fish tissue, and $\bigcirc$ both bed sediment and fish tissue. See table 1 for site names and sample details. (Map modified from 1:100,000 Digital Line Graphs (DLGs) and other digital sources. Universal Transverse Mercator projection, Zone 10, North American Datum 1927.) 
data; that is, concentrations less than the MDL may be reported. In addition, the MDL is statistically based.

The chance of a blank sample being reported as a concentration greater than the MDL (a false positive) is no more than 1 percent. Concentrations less than the MDL are reported if observed; however, they have a greater chance of being false positives. The concentration of an analyte that was not detected in a sample is assumed to be less than $2 \times$ MDL $(2$ times the MDL). The chance of not detecting analyte in a sample with a true concentra- tion equal to $2 \times \mathrm{MDL}$ is no more than 1 percent. Reported concentrations that are less than the $2 \times \mathrm{MDL}$ are semiquantitative - that is, they have greater uncertainty than higher concentrations. MDLs are calculated from the standard deviation of laboratory replicates. The concentration of replicates used to determine the MDLs given in this report was higher than optimal and therefore the MDLs also may be slightly high (Furlong and others, 1996).

Table 1. Sampling summary

[Abbreviations: $\mathrm{mi}^{2}$, square miles; agri, agricultural land; —, not sampled. Land use percentages may not add to 100 due to rounding.]

\begin{tabular}{|c|c|c|c|c|c|c|c|}
\hline \multirow{2}{*}{ Map ID } & \multirow{2}{*}{ Site Name } & \multirow{2}{*}{$\begin{array}{l}\text { Drainage Area } \\
\qquad\left(\mathrm{mi}^{2}\right)\end{array}$} & \multicolumn{3}{|c|}{ Land Use (percent) } & \multicolumn{2}{|c|}{ Sampling Dates and Media } \\
\hline & & & Urban & Agri & Forest & Bed Sediment & Tissue \\
\hline 12 & Ash $\mathrm{Cr}$ at Greenburg $\mathrm{Rd}$ & 4.0 & 100 & 0 & 0 & $9 / 92$ & - \\
\hline 9 & Beaverton $\mathrm{Cr}$ at Cedar Hills Blvd & 6.2 & 98 & 0 & 2 & $8 / 96 *$ & $9 / 96^{*}$ \\
\hline 4 & Bronson $\mathrm{Cr}$ at Walker $\mathrm{Rd}$ & 4.5 & 54 & 22 & 23 & $9 / 92$ & $8 / 96$ \\
\hline 7 & Cedar Mill Cr at Jenkins Rd & 8.1 & 78 & 4 & 18 & - & 9/96 \\
\hline 8 & Cedar Mill Cr at mouth & 8.5 & 75 & 6 & 20 & $9 / 92$ & - \\
\hline 14 & Chicken Cr near Sherwood & 15.3 & 6 & 65 & 29 & $9 / 92$ & - \\
\hline 2 & Dairy $\mathrm{Cr}$ at Susbauer $\mathrm{Rd}$ & 150.1 & 1 & 35 & 64 & $9 / 92$ & $8 / 96^{*}$ \\
\hline 11 & Fanno Cr near Denny Rd & 9.6 & 100 & 0 & 0 & $9 / 96^{*}$ & $9 / 96^{*}$ \\
\hline 13 & Fanno $\mathrm{Cr}$ at Durham $\mathrm{Rd}$ & 31.0 & 92 & 2 & 5 & $9 / 92,10 / 93^{*}$ & $9 / 92,9 / 93^{*}, 8 / 96$ \\
\hline 10 & Upper Fanno Cr at Nicol Rd & 6.6 & 100 & 0 & 0 & $9 / 92$ & $8 / 96$ \\
\hline 1 & Gales Cr near Glenwood & 7.0 & 0 & 0 & 100 & $9 / 92$ & $9 / 92,9 / 96$ \\
\hline 3 & McKay $\mathrm{Cr}$ at Hornecker $\mathrm{Rd}$ & 61.4 & 5 & 42 & 53 & $9 / 92$ & - \\
\hline 6 & Lower Rock Cr at Brookwood Rd & 63.0 & 56 & 26 & 17 & $9 / 92^{*}$ & - \\
\hline 5 & Upper Rock Cr at Baseline $\mathrm{Rd}$ & 26.3 & 26 & 42 & 32 & 9/92 & $8 / 96$ \\
\hline 15 & Tualatin R above Dairy Cr & 230.3 & 3 & 26 & 71 & $9 / 92$ & - \\
\hline 16 & Tualatin R at Elsner Rd & 586.6 & 9 & 38 & 53 & 9/92 & - \\
\hline
\end{tabular}

*Replicate samples were obtained. 
Table 2. Elements and compounds analyzed in this study

[Shaded areas indicate that the medium was analyzed for the listed element or compound; indicates that a guideline or criterion exists for this analytemedium combination and is given in this report (see table 5); letters identify the analytical method (see footnotes); - indicates that no CAS number exists for the given analyte. Abbreviations: Sed, sediment; Tis, tissue; CAS, Chemical Abstracts Service registry number.]

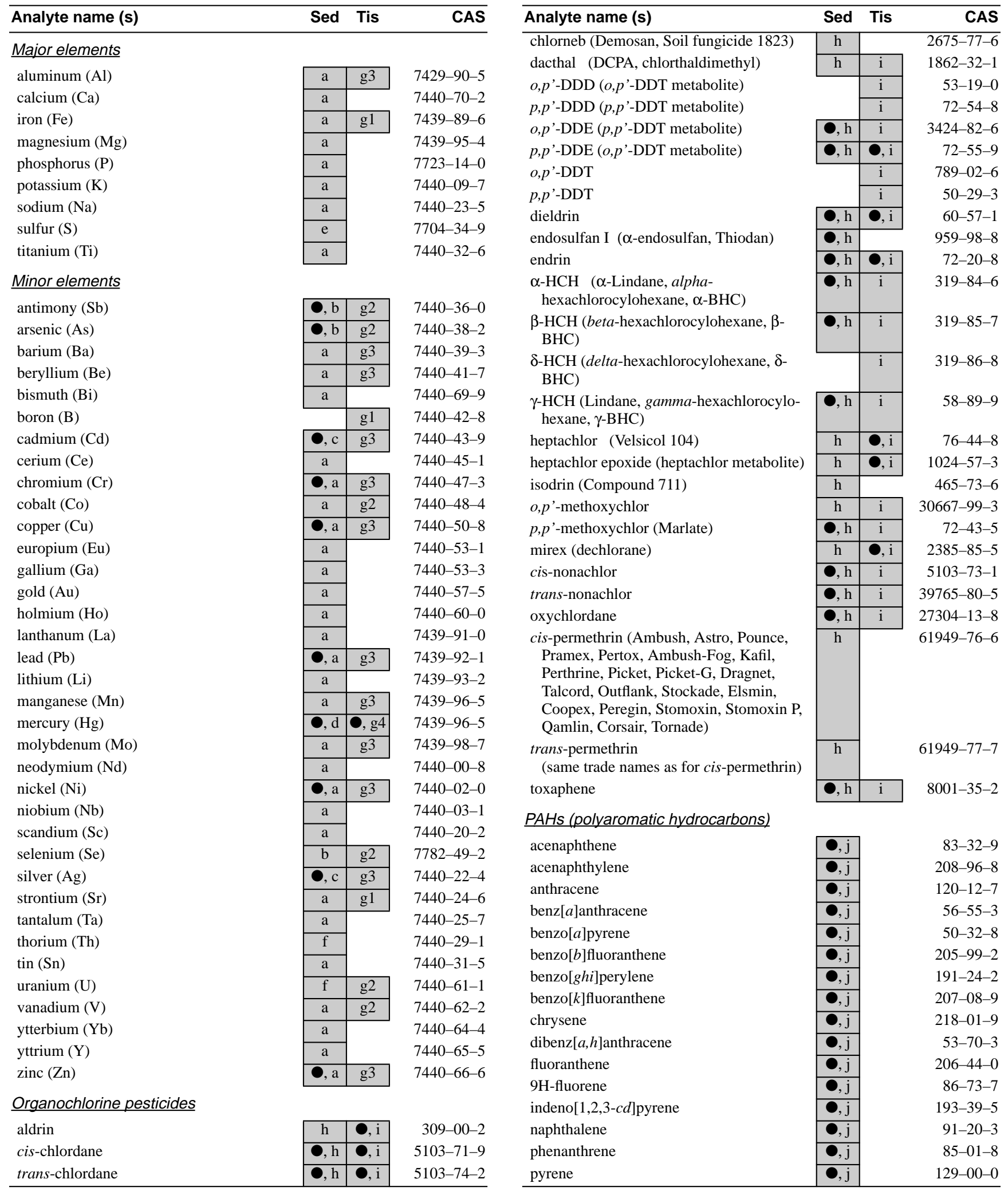




\section{Table 2. Elements and compounds analyzed in this study-Continued}

[Shaded areas indicate that the medium was analyzed for the listed element or compound; $\bullet$ indicates that a guideline or criterion exists for this analytemedium combination and is given in this report (see table 5); letters identify the analytical method (see footnotes); - indicates that no CAS number exists for the given analyte. Abbreviations: Sed, sediment; Tis, tissue; CAS, Chemical Abstracts Service registry number.]

\begin{tabular}{|c|c|c|c|}
\hline Analyte name (s) & Sed & Tis & CAS \\
\hline \multicolumn{4}{|l|}{$\underline{A l k y l-P A H s}$} \\
\hline 1,2-dimethylnaphthalene & $\mathrm{j}$ & & $573-98-8$ \\
\hline 1,6-dimethylnaphthalene & $\bar{j}$ & & $575-43-9$ \\
\hline 2,6-dimethylnaphthalene & $\mathrm{j}$ & & $581-42-0$ \\
\hline 2-ethylnaphthalene & $\mathrm{j}$ & & $939-27-5$ \\
\hline 1-methyl-9H-fluorene & $\mathrm{j}$ & & $1730-37-6$ \\
\hline 1-methylphenanthrene & $\mathrm{j}$ & & $832-69-9$ \\
\hline 1-methylpyrene & $\mathrm{j}$ & & $2381-21-7$ \\
\hline 2-methylanthracene & $\mathrm{j}$ & & $613-12-7$ \\
\hline 4,5-methylenephenanthrene & $\mathrm{j}$ & & $203-64-5$ \\
\hline 2,3,6-trimethylnaphthalene & $\mathrm{j}$ & & $829-26-5$ \\
\hline
\end{tabular}

\section{$\underline{\text { Azaarines }}$}

acridine

benzo[c]cinnoline

2,2'-biquinoline

9H-carbazole

isoquinoline

phenanthridine

quinoline

\begin{tabular}{|l|}
\hline $\mathrm{j}$ \\
\hline $\mathrm{j}$ \\
\hline $\mathrm{j}$ \\
\hline $\mathrm{j}$ \\
\hline $\mathrm{j}$ \\
\hline $\mathrm{j}$ \\
\hline $\mathrm{j}$ \\
\hline
\end{tabular}

260-94-6 230-17-1 119-91-5 86-74-8 119-65-3 229-87-8 91-22-5

\begin{tabular}{|c|c|c|c|}
\hline Analyte name (s) & Sed & Tis & CAS \\
\hline \multicolumn{4}{|l|}{ Phenols } \\
\hline \multirow{6}{*}{$\begin{array}{l}\text { C8-alkylphenol } \\
\text { 2-chlorophenol } \\
\text { 4-chloro-3-methylphenol } \\
\text { p-cresol } \\
\text { 3,5-dimethylphenol } \\
\text { phenol }\end{array}$} & $\mathrm{j}$ & & - \\
\hline & $\bar{j}$ & & $95-57-8$ \\
\hline & $\mathrm{j}$ & & $59-50-7$ \\
\hline & $\mathbf{0}, \mathrm{j}$ & & $106-44-5$ \\
\hline & $\mathrm{j}$ & & $108-68-9$ \\
\hline & $\mathbf{0}, \mathrm{j}$ & & $108-95-2$ \\
\hline \multicolumn{4}{|l|}{ Chlorinated aromatic compounds } \\
\hline \multirow{9}{*}{$\begin{array}{l}\text { 2-chloronaphthalene } \\
\text { 1,2-dichlorobenzene } \\
\text { 1,3-dichlorobenzene } \\
\text { 1,4-dichlorobenzene } \\
\text { hexachlorobenzene } \\
\text { pentachloroanisole } \\
\text { pentachloronitrobenzene } \\
\text { polychlorinated biphenyls (total-PCB) } \\
\text { 1,2,4-trichlorobenzene }\end{array}$} & $\mathrm{j}$ & & $91-58-7$ \\
\hline & $\mathbf{O}, \mathrm{j}$ & & $95-50-1$ \\
\hline & $\mathbf{0}, \mathrm{j}$ & & $541-73-1$ \\
\hline & $\mathbf{O}, \mathrm{j}$ & & $106-46-7$ \\
\hline & $0, \mathrm{~h}$ & $\mathbf{O}, \mathrm{i}$ & $118-74-1$ \\
\hline & $\mathrm{h}$ & i & $1827-21-4$ \\
\hline & $\mathrm{j}$ & & $82-68-5$ \\
\hline & $\mathbf{O}, \mathrm{h}$ & $\mathbf{O}, \mathrm{i}$ & - \\
\hline & $\mathbf{O}, \mathrm{j}$ & & $120-82-1$ \\
\hline \multicolumn{4}{|l|}{ Other } \\
\hline \multirow{3}{*}{$\begin{array}{l}\text { anthraquinone } \\
\text { azobenzene } \\
\text { bis(2-chloroethoxy)methane }\end{array}$} & $\mathrm{j}$ & & $84-65-1$ \\
\hline & $\mathrm{j}$ & & $103-33-3$ \\
\hline & $\mathrm{j}$ & & $111-91-1$ \\
\hline \multirow{3}{*}{$\begin{array}{l}\text { 4-bromophenyl-phenylether } \\
\text { 4-chlorophenyl-phenylether } \\
\text { dibenzothiophene }\end{array}$} & $\mathbf{0}, \mathrm{j}$ & & $101-55-3$ \\
\hline & $\mathrm{j}$ & & $7005-72-3$ \\
\hline & $\mathrm{j}$ & & $132-65-0$ \\
\hline \multirow{2}{*}{$\begin{array}{l}\text { 2,4-dinitrotoluene } \\
\text { isophorone }\end{array}$} & $\mathrm{j}$ & & $121-14-2$ \\
\hline & $\mathrm{j}$ & & $78-79-1$ \\
\hline \multirow{3}{*}{$\begin{array}{l}\text { nitrobenzene } \\
\mathrm{N} \text {-nitrosodiphenylamine } \\
\mathrm{N} \text {-nitrosodi- } n \text {-propylamine } \\
\end{array}$} & $\mathrm{j}$ & & $98-95-3$ \\
\hline & $\mathbf{0 , j}$ & & $86-30-6$ \\
\hline & $\mathrm{j}$ & & $621-64-7$ \\
\hline
\end{tabular}

\section{Phthalates}

bis(2-ethylhexyl)phthalate

butylbenzylphthalate

diethylphthalate

dimethylphthalate

di- $n$-butylphthalate

di- $n$-octylphthalate



$117-81-7$

85-68-7

84-66-2

131-11-3

84-74-2

$117-84-0$

a-Homogenized bed sediment was digested using a mixture of hydrochloric, nitric, perchloric and hydrofluoric acids at low temperature. The resulting solution was evaporated to dryness, dissolved in aqua regia, and analyzed by ICP-AES (inductively coupled plasma/atomic emission spectrometry). (Briggs, 1990)

$\mathrm{b}-$ Homogenized bed sediment was digested using a mixture of nitric, perchloric and hydrofluoric acids at $105-110^{\circ} \mathrm{C}$. The resulting solution was analyzed by HG-AAS (hydride generation atomic absorption spectrophotometry). (Welsch and others, 1990)

c-Homogenized bed sediment was digested with hydrofluoric acid, hydrochloric acid, and hydrogen peroxide. The resulting solution was extracted into an organic phase which was analyzed using FAA (flame atomic absorption spectrometry). (O'Leary and Viets, 1986).

$\mathrm{d}-$ Homogenized bed sediment was digested using nitric acid and sodium dichromate. Mercury in the digest was reduced to elemental form and analyzed by continuous-flow CV-AAS (cold-vapor atomic absorption spectrophotometry). (O'Leary and others, 1990)

e-Homogenized bed sediment was analyzed by combustion with infrared absorption detection using an automated sulfur analyzer. (Curry, 1990)

f-Homogenized bed sediment was irradiated with neutrons. Delayed neutrons from the sample were counted. (McKown and Knight, 1990)

$\mathrm{g}$ - Homogenized tissue was digested using nitric acid followed by hydrogen peroxide. The resulting solution was dried, reconstituted with nitric acid and filtered. The filtrate was analyzed by (1) ICP-AES, (2) ICP-MS (inductively coupled plasma/mass spectrometry), (3) both ICP-AES and ICP-MS with the reported result depending on the magnitude of the concentration, or (4) CV-AAS. (Hoffman, 1996)

$\mathrm{h}-$ Homogenized bed sediment was Soxhlet extracted. Gel permeation chromatography was used to remove inorganic sulfur and large natural molecules. The extract was fractionated using alumina/silica adsorption. The extracts were analyzed by GC-ECD (gas chromatography with electron capture detection). (Foreman and others, 1995)

i-Homogenized tissue was Soxhlet extracted. Lipid was removed by gel permeation chromatography and the extract was fractionated using alumina/ silica adsorption. The extracts were analyzed by GC-ECD. (Leiker and others, 1995)

j-Homogenized bed sediment was Soxhlet extracted. Gel permeation chromatography was used to remove inorganic sulfur and large natural molecules. The extract was analyzed by GC-MS (gas chromatography with mass spectrometry). (Furlong and others, 1996) 
Variability- Four sets of replicate bed sediment samples were collected and analyzed. All replicate sets include the variability associated with sample preparation (homogenization, sieving) and with the chemical analysis itself. However, because the method of collection for the replicate sets varied, some sets include more sources of variability than others. For example, the replicates from the Fanno Creek at Durham site were collected from different subreaches, and therefore also include spatial variability and the variability associated with the collection of separate samples. The characteristics of the replicate sample sets are summarized and compared in table 3 .

For both elements and organic chemicals, the replicate set with the greatest variability was the one that included a spatial variability component. The increased variability was conspicuous for the organic compounds; the variability in this replicate set exceeded that in all the other replicate sets for every organic compound that could be compared. Because spatial variability appears to be important, data from the Fanno Creek at Durham replicate set was averaged to make it more comparable with other samples in the data set, and the average value was used in data analysis and interpretation. The variability for the Lower Rock Creek replicate set, which incorporated a sample col- lection component, exceeded that of simple split replicate sets, but only for elements—not for organic compounds. The composite sample from the Lower Rock Creek replicate set was used in data analysis.

Analytical uncertainty was estimated for each analyte as the maximum range among replicate sets (other than the Fanno Creek at Durham sediment set). These values are given in Appendices B and D. For most elements in sediment, analytical uncertainty ranged from less than 5 percent to about 20 percent. Results near the reporting limits have greater uncertainty. For the organic compounds in sediment, analytical uncertainty was somewhat higher, generally 10-30 percent with greater uncertainty at low concentrations. In several instances, an individual organic analyte was detected in some, but not all, samples in the replicate set.

Replicate ranges for tissue samples were higher than those for sediment samples. For elements, ranges were about 20-200 percent; for organochlorine compounds, ranges were about 10-70 percent. Greater uncertainty for tissue samples is expected because each replicate was a composite of different individual fish (not a split of homogenized tissue) and because tissue matrices are inherently difficult to analyze. Ranges among the tissue replicate sets were not statistically different from each other.

Table 3. Comparison of replicate sediment samples

$[\mathrm{N}$ is the number of replicates in the set. Sets that have different group identifier letters are statistically different $(\alpha=0.05)$; those with the same letters are not statistically different. In this case, group A denotes the largest variability and group C denotes the least variability. Group identifiers for the elements are independent of those for the organic compounds. The procedure used to determine group identifiers is explained in detail in Appendix A.]

\begin{tabular}{|c|c|c|c|c|c|c|c|c|}
\hline & & & & Varia & bility & & Stat & stical \\
\hline & & Replicate set & $\delta$ & $\frac{\delta}{\frac{0}{\bar{\sigma}}}$ & & & $\begin{array}{l}\text { com } \\
\text { (group }\end{array}$ & $\begin{array}{l}\text { arison } \\
\text { dentifier) }\end{array}$ \\
\hline Site & $\mathbf{N}$ & Description & 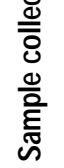 & $\frac{\frac{0}{0}}{\frac{0}{0}}$ & $\frac{\overline{8}}{\frac{8}{2}}$ & 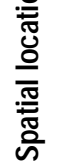 & $\begin{array}{l}\text { Elements } \\
\quad(36)\end{array}$ & $\begin{array}{c}\text { Organic } \\
\text { compounds } \\
(8)\end{array}$ \\
\hline $\begin{array}{l}\text { Beaverton } \mathrm{Cr} \\
\text { (1996) }\end{array}$ & 2 & Split of composite sample & & $x$ & $x$ & & $\mathrm{C}$ & B \\
\hline $\begin{array}{l}\text { Fanno Cr at Denny Rd } \\
\text { (1996) }\end{array}$ & 2 & Split of composite sample & & $x$ & $x$ & & $\mathrm{C}$ & $\mathrm{C}$ \\
\hline $\begin{array}{l}\text { Fanno Cr at Durham Rd } \\
\text { (1993) }\end{array}$ & 3 & $\begin{array}{l}\text { Three composited samples obtained at three differ- } \\
\text { ent subreaches at the same site }\end{array}$ & $x$ & $x$ & $x$ & $x$ & A & A \\
\hline $\begin{array}{l}\text { Lower Rock Cr } \\
\text { (1992) }\end{array}$ & 3 & $\begin{array}{l}\text { Two samples obtained by different personnel; } \\
\text { third sample composite of first two }\end{array}$ & $x$ & $x$ & $x$ & & B & $\mathrm{C}$ \\
\hline
\end{tabular}


Contamination- Field blanks were not submitted because no suitable material exists for sediment or tissue. To assess contamination, the laboratory routinely analyzed blanks consisting of sodium sulfate. No contamination problems were reported for elements or for organochlorine pesticides. For five semivolatile organic compounds, contamination was relatively common, occurring in 30-80 percent of laboratory blanks (Lopes and others, 1998). Those compounds and the 95th percentile concentration of laboratory blank samples (B95) are bis(2-ethylhexyl)phthalate $(100 \mathrm{ng} / \mathrm{g})$, butylbenzylphthalate $(64 \mathrm{ng} / \mathrm{g})$, diethylphthalate $(25 \mathrm{ng} / \mathrm{g})$, di- $n$-butylphthalate $(54 \mathrm{ng} / \mathrm{g})$, and phenol $(27 \mathrm{ng} / \mathrm{g})$. To minimize the risk of overestimating environmental concentrations of these analytes, environmental concentrations less than the B95 value were not considered detections. Environmental concentrations greater than the B95 value were adjusted by subtracting the B95 value.

Analytical method performance- As part of the analytical method for organic compounds (organochlorine pesticides and the semivolatile compounds), environmental samples are spiked at the laboratory with several surrogate compounds. These compounds, which are often deuterated, are not expected to be present in a natural environmental sample. The percent recovery of the surrogate compounds provides an indication of the overall method performance for that sample. Surrogate recoveries cannot be used to adjust concentrations in a sample because the surrogates were not chosen to closely mimic the behavior of any individual analyte. Surrogate recoveries for bed sediment samples in this study were comparable to typical laboratory performance (table 4). Surrogate recoveries from fish tissue, however, were occasionally much poorer than typical laboratory performance, including nine instances in which the percent recovery equalled zero. All but one of these cases occurred for samples collected in 1992-1993 and analyzed when the laboratory was inexperienced in the use of this analytical method. Therefore, it is possible that the environmental concentrations measured in some of these tissue samples are biased low.

\section{Data analysis}

Comparisons to guidelines and other data-

Data obtained in this study were compared to a variety of published values (table 5). Concentrations of elements and organic compounds in bed sediment were compared to screening values used by the USEPA for

Table 4. Comparison of surrogate recovery for Tualatin data with expected laboratory performance

[Means, standard deviations, and ranges all in units of percent; $\mathrm{N}$ is the number of samples.]

\begin{tabular}{|c|c|c|c|c|c|c|c|c|}
\hline \multirow[b]{2}{*}{ Compound } & \multicolumn{4}{|c|}{ Tualatin data } & \multicolumn{4}{|c|}{ Laboratory performance } \\
\hline & Mean & $\begin{array}{l}\text { Standard } \\
\text { deviation }\end{array}$ & Range & $\mathbf{N}$ & Mean & $\begin{array}{l}\text { Standard } \\
\text { deviation }\end{array}$ & Range & $\mathbf{N}$ \\
\hline \multicolumn{9}{|c|}{ GC-ECD Method - Sediment (for organochlorine pesticides and total PCB) } \\
\hline 3,5-dichlorobiphenyl & 61 & 5 & $52-71$ & 20 & 61 & 16 & $11-105$ & 121 \\
\hline$\alpha-\mathrm{HCH}-d_{6}$ & 71 & 9 & $40-85$ & 20 & 67 & 14 & $34-110$ & 121 \\
\hline PCB-204 & 66 & 12 & $46-85$ & 20 & 74 & 20 & $32-135$ & 119 \\
\hline \multicolumn{9}{|c|}{ GC-MS Method-Sediment (for semivolatile organic compounds such as PAHs, phthalates, and phenols) } \\
\hline 2-fluorobiphenyl & 64 & 23 & $29-120$ & 20 & 65 & 20 & $13-107$ & 132 \\
\hline nitrobenzene- $d_{5}$ & 63 & 15 & $30-80$ & 20 & 64 & 22 & $13-107$ & 132 \\
\hline terphenyl- $d_{14}$ & 79 & 19 & $38-100$ & 16 & 75 & 17 & $25-129$ & 132 \\
\hline \multicolumn{9}{|c|}{ GC-ECD Method-Tissue (for organochlorine pesticides and total PCB) } \\
\hline 3,5-dichlorobiphenyl & 41 & 28 & $0-75$ & 17 & 66 & 22 & $35-113$ & 114 \\
\hline$\alpha-\mathrm{HCH}-d_{6}$ & 64 & 40 & $0-95$ & 15 & 76 & 18 & $11-160$ & 121 \\
\hline
\end{tabular}


Table 5. Screening values and guidelines for elements and organic compounds assayed in this study

[Sediment screening values from National Sediment Quality Survey (U.S. Environmental Protection Agency, 1997). Tissue guidelines from National Academy of Sciences/National Academy of Engineering (NAS/NAE, 1973), and New York State criteria (NY) for fish in the Niagara River (Newell and others, 1987). Abbreviations are as follows: $\mu \mathrm{g} / \mathrm{g}$ org C, microgram per gram of organic carbon; $\mu \mathrm{g} / \mathrm{g}$, microgram per gram.]

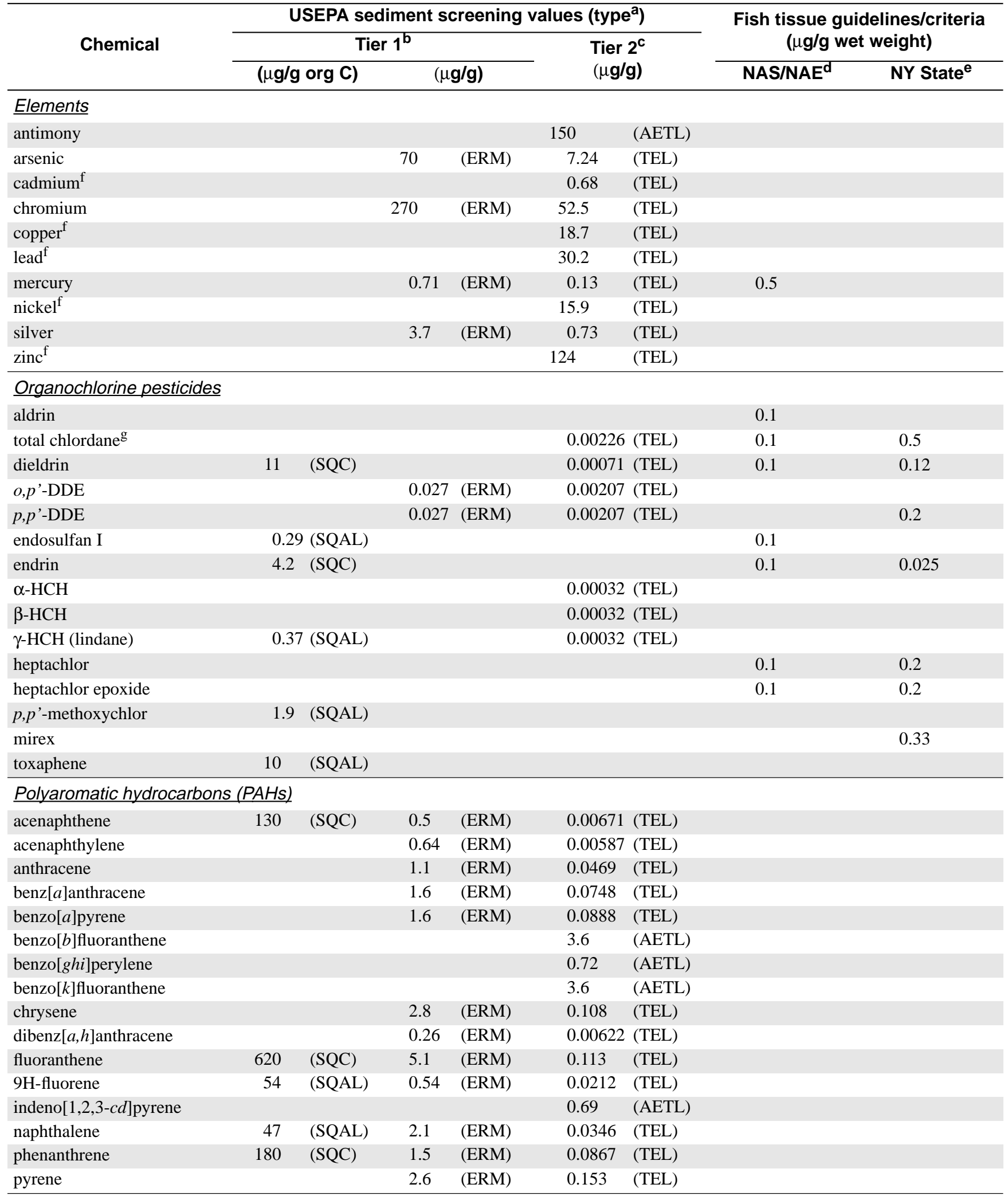


Table 5. Screening values and guidelines for elements and organic compounds assayed in this study—Continued

[Sediment screening values from National Sediment Quality Survey (U.S. Environmental Protection Agency, 1997). Tissue guidelines from National Academy of Sciences/National Academy of Engineering (NAS/NAE, 1973), and New York State criteria (NY) for fish in the Niagara River (Newell and others, 1987). Abbreviations are as follows: $\mu \mathrm{g} / \mathrm{g}$ org C, microgram per gram of organic carbon; $\mu \mathrm{g} / \mathrm{g}$, microgram per gram.]

\begin{tabular}{|c|c|c|c|c|c|c|c|}
\hline \multirow{3}{*}{ Chemical } & \multicolumn{5}{|c|}{ USEPA sediment screening values $\left(\right.$ type $^{\mathrm{a}}$ ) } & \multirow{2}{*}{\multicolumn{2}{|c|}{$\begin{array}{l}\text { Fish tissue guidelines/criteria } \\
\text { ( } \mu \mathrm{g} / \mathrm{g} \text { wet weight) }\end{array}$}} \\
\hline & \multicolumn{3}{|c|}{ Tier $\mathbf{1}^{\mathrm{b}}$} & \multirow{2}{*}{\multicolumn{2}{|c|}{$\begin{array}{l}\text { Tier } 2^{\mathrm{c}} \\
(\mu \mathrm{g} / \mathrm{g})\end{array}$}} & & \\
\hline & $(\mu \mathrm{g} / \mathrm{c}$ & $\operatorname{org} \mathbf{C )}$ & $(\mu \mathbf{g} / \mathbf{g})$ & & & NAS/NAE $^{d}$ & NY State S $^{e}$ \\
\hline \multicolumn{8}{|l|}{ Phthalates } \\
\hline bis(2-ethylhexyl)phthalate & & & $2.65 \quad(\mathrm{PEL})$ & 0.182 & (TEL) & & \\
\hline butylbenzylphthalate & 1100 & (SQAL) & & 0.9 & (AETL) & & \\
\hline diethylphthalate & 63 & (SQAL) & & 0.2 & (AETL) & & \\
\hline dimethylphthalate & & & & 0.16 & (AETL) & & \\
\hline di- $n$-butylphthalate & 1100 & (SQAL) & & 1.4 & (AETL) & & \\
\hline di- $n$-octylphthalate & & & & 6.2 & $(\mathrm{AETL})$ & & \\
\hline \multicolumn{8}{|l|}{ Phenols } \\
\hline$p$-cresol & & & & 0.67 & (AETL) & & \\
\hline phenol & & & & 0.42 & (AETL) & & \\
\hline \multicolumn{8}{|c|}{ Chlorinated aromatic compounds } \\
\hline 1,2-dichlorobenzene & 34 & (SQAL) & & 0.05 & (AETL) & & \\
\hline 1,3-dichlorobenzene & 170 & (SQAL) & & & & & \\
\hline 1,4-dichlorobenzene & 34 & (SQAL) & & 0.05 & (AETL) & & \\
\hline hexachlorobenzene & & & & 0.022 & (AETL) & & 0.33 \\
\hline total PCB & & & 0.189 (PEL) & 0.0216 & (TEL) & 0.5 & 0.11 \\
\hline 1,2,4-trichlorobenzene & 920 & (SQAL) & & 0.051 & (AETL) & & \\
\hline \multicolumn{8}{|l|}{ Other organic compounds } \\
\hline 4-bromophenyl-phenylether & 130 & (SQAL) & & & & & \\
\hline $\mathrm{N}$-nitrosodiphenylamine & & & & 0.028 & (AETL) & & \\
\hline \multicolumn{8}{|c|}{$\begin{array}{l}\text { a-Type refers to the original sources of the guideline, abbreviated as follows: ERM, effects range median; AETL, apparent effects threshold-low; } \\
\text { PEL, probable effects level; TEL, threshold effects level; SQC, sediment quality criteria; SQAL, sediment quality advisory level. } \\
\text { b-"Tier 1" is defined by the USEPA as "associated adverse effects to aquatic life or human health are probable." } \\
\text { c--"Tier } 2 \text { " is defined by the USEPA as "associated adverse effects to aquatic life or human health are possible, but expected infrequently." } \\
\text { d--"Recommended maximum tissue concentration for the protection of fish and wildlife." } \\
\text { e--Criteria for the protection of piscivorous wildlife." } \\
\text { f-Tier } 1 \text { screening values for these elements are not given here because they based on the difference between the element concentration and the acid } \\
\text { volatile sulfide concentration. } \\
\text { g-Total chlordane is the sum of cis-chlordane, trans-chlordane, cis-nonachlor, trans-nonachlor, and oxychlordane. }\end{array}$} \\
\hline
\end{tabular}

their National Sediment Quality Inventory (U.S. Environmental Protection Agency, 1997). For the elements cadmium, copper, lead, nickel and zinc, the USEPA Tier 1 screening values are not based solely on element concentration, but also involve the acid-volatile sulfide concentration. This is because these elements form highly insoluble sulfide compounds, and therefore, have low bioavailability. The acid-volatile sulfide concentration was not measured in this study. For a few organic compounds, the organic carbon content is taken into account by using sediment quality criteria
(SQCs) or sediment quality advisory levels (SQALs), both of which normalize concentrations to organic carbon. SQCs and SQALs have not been set for most organic compounds.

Relatively few guidelines exist for the concentrations of contaminants in fish tissue. Many of those that do exist pertain to human health concerns and are limited to contaminant concentrations in muscle fillets of edible fish. Such guidelines are not appropriate for this study because sculpin are not likely to be used for human consumption, and because all tissue samples 
analyzed in this study were whole-body. The New York State criteria (Newell and others, 1987) and the National Academy of Sciences/National Academy of Engineering (NAS/NAE) guidelines (NAS/NAE, 1973) are for the protection of fish and wildlife and therefore apply in this study.

To place the concentrations of elements and organic compounds found in the Tualatin Basin in context, in this report they will be compared to values reported for the Willamette Basin and also to a national distribution. Both the Willamette data and the national data were collected by the USGS National Water-Quality Assessment Program (NAWQA) between 1992 and 1995 (Wentz, Bonn, and others, 1998). The national distribution contains data from 20 large river basins, and includes the Willamette data. In general, both the Willamette data and the national data are from mostly agricultural sites; relatively few urban sites are included in either data set. Differences between the Tualatin data and either of these data sets may be caused by the preponderance of urban sites in the Tualatin Basin.

\section{Influence of sample processing methods on data interpretation- Contaminant concentrations} can be influenced by the methods used to collect and process samples. When comparing the data in this report to published guidelines or to data from other studies, it is important to consider differences in collection and processing methods.

Trace element concentrations reported in this study are probably higher than they would have been had the samples not been sieved at $63 \mu \mathrm{m}$. This is because sieving at $63 \mu \mathrm{m}$ removes the sand-sized fraction, which is not expected to significantly sorb trace elements. The amount of material excluded from analysis by sieving at $63 \mu \mathrm{m}$ ranged from about 20 to 80 percent, with one exception. The amount of sand-sized particles at the Gales Creek site was larger than that of any other site-93 percent.

Concentrations of organic compounds were probably not changed significantly by sieving at $2 \mathrm{~mm}$. Sieving at $2 \mathrm{~mm}$ removes very little material—only pebbles and debris-and is not expected to alter the organic carbon content of the sample. Because samples that naturally contain more organic carbon might also contain more organic contaminants, concentrations of organic compounds are often normalized to organic carbon content. The organic carbon content of samples ranged from less than 1 percent to about 4 percent.
The USEPA sediment screening values apply to unsieved sediment samples. Because the samples analyzed for elements were sieved at $63 \mu \mathrm{m}$, the likelihood of exceeding a screening value is increased. It is possible for the element concentration in a sieved sample to exceed a screening value when the concentration in the unsieved sample does not. In contrast, exceedances of USEPA screening values for organic compounds are probably not changed by sieving at $2 \mathrm{~mm}$.

The sample collection and processing methods used in this study were the same as those used by the NAWQA program. Therefore, comparisons between these three data sets should not be affected by sampling methods.

Statistical methods- Nonparametric procedures and statistics were used extensively in this report. Such procedures do not rely on an assumption that the data are normally distributed-an assumption that is not likely to be met. Summary statistics were generally limited to percentiles. Most correlations were performed using the Spearman rank technique; when graphical examination showed approximate linearity, Pearson correlation (a parametric method) was used.

Summary statistics were calculated using the observed data combined with "fill in" values (calculated using probability plot procedures) for nondetections (Helsel and Hirsch, 1992). This method avoids the problems of either simple substitution for nondetections or of assuming a distributional shape. When an MRL was used by the laboratory, it was used as the upper limit of nondetections to calculate summary statistics; when an MDL was used by the laboratory, $2 \times$ MDL was used as the upper limit of nondetections.

Principal components analysis- Principal components analysis (PCA) was used as an exploratory tool to reveal patterns among chemical constituents. PCA is a multivariate technique that is frequently used to reduce the dimensionality of data sets with many variables (Davis, 1973; Joliffe, 1986). Although PCA is a parametric method, its use here is limited to data exploration and not extended to modeling. All PCA were performed three ways: on raw data, on log-transformed data (to improve normality), and on data ranks (to approximate a nonparametric test). Differences among results of the three methods were negligible, indicating that any lack of normality did not alter the validity or the nature of patterns identified by PCA. Only the results from the PCA using raw data are presented in this report. 


\section{RESULTS}

\section{Overview of concentrations}

Bed sediment- Summary statistics for concentrations of elements in sediment are given in table 6. Trace element concentrations were similar to those found in Willamette Basin sediment and toward the lower end of the national distribution (fig. 2). USEPA Tier 1 screening values for arsenic, chromium, and mercury were never exceeded. However, every sample, including those from the most remote sites such as Gales Creek, exceeded the Tier 2 screening values for chromium, copper, and nickel. These elements may have natural as well as anthropogenic sources. Other elements, such as lead and cadmium, also exceeded Tier 2 screening values, but only at sites with urban influences. Comparisons to Tier 1 screening values could not be made for cadmium, copper, lead, nickel, and zinc because the acid-volatile sulfide concentration was not known.

Most organochlorine compounds were not detected in Tualatin Basin sediments (table 7, p. 16-17). When organochlorines were detected, concentrations were similar to those elsewhere in the Willamette Basin and the Nation (fig. 3, p. 18-19). The most commonly detected organochlorine was p,p'-DDE, which was detected at about two-thirds of the sites. This compound is a metabolite of the insecticide DDT, which was banned from use in the United States in 1972. The fact that it is detected relatively frequently demonstrates the persistence of this family of compounds in the environment. Concentrations of p,p'-DDE were generally low, but did exceed the USEPA Tier 2 screening value at four sites. Chlordanes (cis- and trans-chlordane and cis- and trans-nonachlor) were detected at about one-third of the sites. The USEPA Tier 2 screening value for total chlordane was exceeded at five sites. Total chlordane is the sum of $c i s$ - and trans-chlordane, cis- and trans-nonachlor, and oxychlordane.

The most commonly detected semivolatile compounds were PAHs, phthalates, and $p$-cresol (table 7). PAHs were detected in sediment more frequently in the Tualatin Basin than in either the Willamette Basin or the Nation (table 8, p. 20). This is probably because the Tualatin data set contains more sites with urban influence than either the Willamette Basin or national data sets, which contained predominantly agricultural sites. The concentration data are consistent with this explanation: when PAHs were detected, concentrations in the Tualatin sediments were similar to those elsewhere (fig. 3). PAH concentrations frequently exceeded
USEPA Tier 2 screening values, but never exceeded Tier 1 values.

Phthalate concentrations in Tualatin Basin sediments appear to be high compared with Willamette Basin or national values. At several sites, concentrations of bis(2-ethylhexyl)phthalate, butylbenzylphthalate, and di- $n$-octylphthalate exceeded the Willamette Basin ranges and were near the upper end of the national ranges. These three phthalates were also more frequently detected in Tualatin basin sediments (data not shown). Concentrations of bis(2-ethylhexyl)phthalate exceeded the USEPA Tier 2 screening value at eight sites, two of which had concentrations that exceeded the Tier 1 value. This was the only compound which had an exceedance of a Tier 1 screening value.

Fish tissue - Summary statistics for element concentrations in fish tissue are given in table 9 (p. 20). Trace element concentrations in fish tissue were similar to those for the Willamette Basin and toward the lower end of the national ranges (fig. 4, p. 21). Some of the differences may be because only sculpin were collected for the Tualatin study whereas several kinds of fish were collected for the other studies.

As in sediment, most organochlorine compounds were not detected in fish tissue from Tualatin Basin streams (table 10, p. 22). Generally, the organochlorines that were detected in tissue were the same ones that were detected in sediment- $-p, p$ '-DDE and chlordanes. Dieldrin, however, was detected in fish tissue at eight sites, but in sediment from only three sites. Detection frequencies were greater for the Tualatin Basin tissue samples than for the Willamette Basin tissue samples (table 11, p. 22). Concentrations of organochlorine pesticides in fish tissue were similar to those in a nationwide sample, but occasionally higher than those in the Willamette Basin (fig. 5, p. 23). Two compounds, $\alpha-\mathrm{HCH}$ and heptachlor epoxide, were found in Tualatin Basin fish tissue, but not in Willamette Basin fish tissue. Total chlordane concentrations at three Tualatin Basin sites exceeded the Willamette Basin range; at two of these sites the NAS/NAE guideline was also exceeded. The greater detection frequency and concentration of organochlorine pesticides in the Tualatin Basin compared to those in the Willamette Basin may reflect the large proportion of sites with urban influences in the Tualatin Basin data set. PCBs were relatively common in fish tissue, but concentrations were similar to those in the Willamette Basin. The New York State criterion for PCBs in fish tissue was exceeded at three sites. 
Table 6. Summary statistics for element concentrations in bed sediment

[Concentrations of major elements in milligram per gram $(\mathrm{mg} / \mathrm{g})$; minor elements in microgram per gram $(\mu \mathrm{g} / \mathrm{g})$; all concentrations are expressed on a dry weight basis and are given to one or two significant digits. Abbreviations: P10, P25, P75, and P90, the 10th, 25th, 75th, and 90th percentiles, respectively.]

\begin{tabular}{|c|c|c|c|c|c|c|c|}
\hline Element & Minimum & P10 & P25 & Median & P75 & P90 & Maximum \\
\hline \multicolumn{8}{|c|}{ Major elements $(\mathrm{mg} / \mathrm{g})$} \\
\hline aluminum & 65 & 65 & 68 & 72 & 74 & 76 & 78 \\
\hline calcium & 11 & 12 & 13 & 14 & 18 & 20 & 26 \\
\hline iron & 40 & 40 & 42 & 52 & 56 & 67 & 85 \\
\hline magnesium & 6.5 & 6.6 & 6.9 & 7.5 & 8.7 & 15 & 22 \\
\hline phosphorus & 0.9 & 1.1 & 1.2 & 1.4 & 1.8 & 2.0 & 2.0 \\
\hline potassium & 8 & 10 & 12 & 13 & 15 & 15 & 15 \\
\hline sodium & 9 & 10 & 12 & 14 & 15 & 16 & 16 \\
\hline sulfur* & $<0.5$ & $<0.5$ & $<0.5$ & 0.6 & 0.7 & 0.9 & 1.0 \\
\hline titanium & 6.7 & 6.8 & 7.1 & 8.3 & 9.8 & 14 & 19 \\
\hline \multicolumn{8}{|c|}{ Minor elements $(\mu \mathrm{g} / \mathrm{g})$} \\
\hline antimony & 0.7 & 0.7 & 0.9 & 1.0 & 2.0 & 2.0 & 3.0 \\
\hline arsenic & 2.0 & 3.5 & 4.4 & 7.0 & 9.0 & 10 & 16 \\
\hline barium & 280 & 280 & 580 & 640 & 680 & 690 & 730 \\
\hline beryllium & $<1$ & $<1$ & 1 & 2 & 2 & 2 & 2 \\
\hline cadmium & 0.2 & 0.2 & 0.2 & 0.3 & 0.8 & 1.1 & 1.2 \\
\hline cerium & 48 & 53 & 62 & 66 & 76 & 80 & 87 \\
\hline chromium & 59 & 65 & 71 & 75 & 80 & 100 & 140 \\
\hline cobalt & 17 & 18 & 21 & 22 & 25 & 29 & 40 \\
\hline copper & 20 & 20 & 24 & 32 & 45 & 55 & 67 \\
\hline gallium & 16 & 17 & 18 & 18 & 20 & 22 & 22 \\
\hline lanthanum & 28 & 32 & 38 & 40 & 44 & 46 & 48 \\
\hline lead & $<4$ & 7 & 18 & 30 & 54 & 63 & 130 \\
\hline lithium* & 20 & 20 & 20 & 20 & 30 & 30 & 30 \\
\hline manganese & 880 & 1000 & 1100 & 1400 & 1600 & 2100 & 2200 \\
\hline mercury & $<0.02$ & 0.03 & 0.05 & 0.07 & 0.11 & 0.24 & 0.30 \\
\hline neodymium* & 25 & 32 & 34 & 35 & 38 & 42 & 43 \\
\hline nickel & 18 & 21 & 22 & 25 & 28 & 40 & 50 \\
\hline niobium & 11 & 12 & 12 & 14 & 17 & 21 & 35 \\
\hline scandium & 14 & 14 & 15 & 18 & 20 & 23 & 25 \\
\hline selenium & $<0.1$ & 0.1 & 0.2 & 0.2 & 0.3 & 0.6 & 0.9 \\
\hline silver & $<0.1$ & $<0.1$ & 0.2 & 0.2 & 0.4 & 0.9 & 1.3 \\
\hline strontium & 200 & 200 & 220 & 250 & 260 & 280 & 300 \\
\hline thorium* & 5.8 & 8.2 & 11 & 12 & 14 & 16 & 16 \\
\hline uranium & 1.5 & 2.7 & 2.9 & 3.4 & 3.7 & 4.1 & 4.6 \\
\hline vanadium & 110 & 120 & 130 & 160 & 170 & 240 & 280 \\
\hline yttrium & 21 & 23 & 24 & 27 & 28 & 30 & 32 \\
\hline ytterbium* & 2 & 2 & 2 & 2 & 3 & 3 & 3 \\
\hline zinc & 120 & 120 & 130 & 150 & 220 & 340 & 400 \\
\hline
\end{tabular}

The following elements were not detected in bed sediment samples: bismuth, europium, gold, holmium, molybdenum, tantalum, tin.

\footnotetext{
*The estimated analytical precision equals or exceeds the interquartile range.
} 


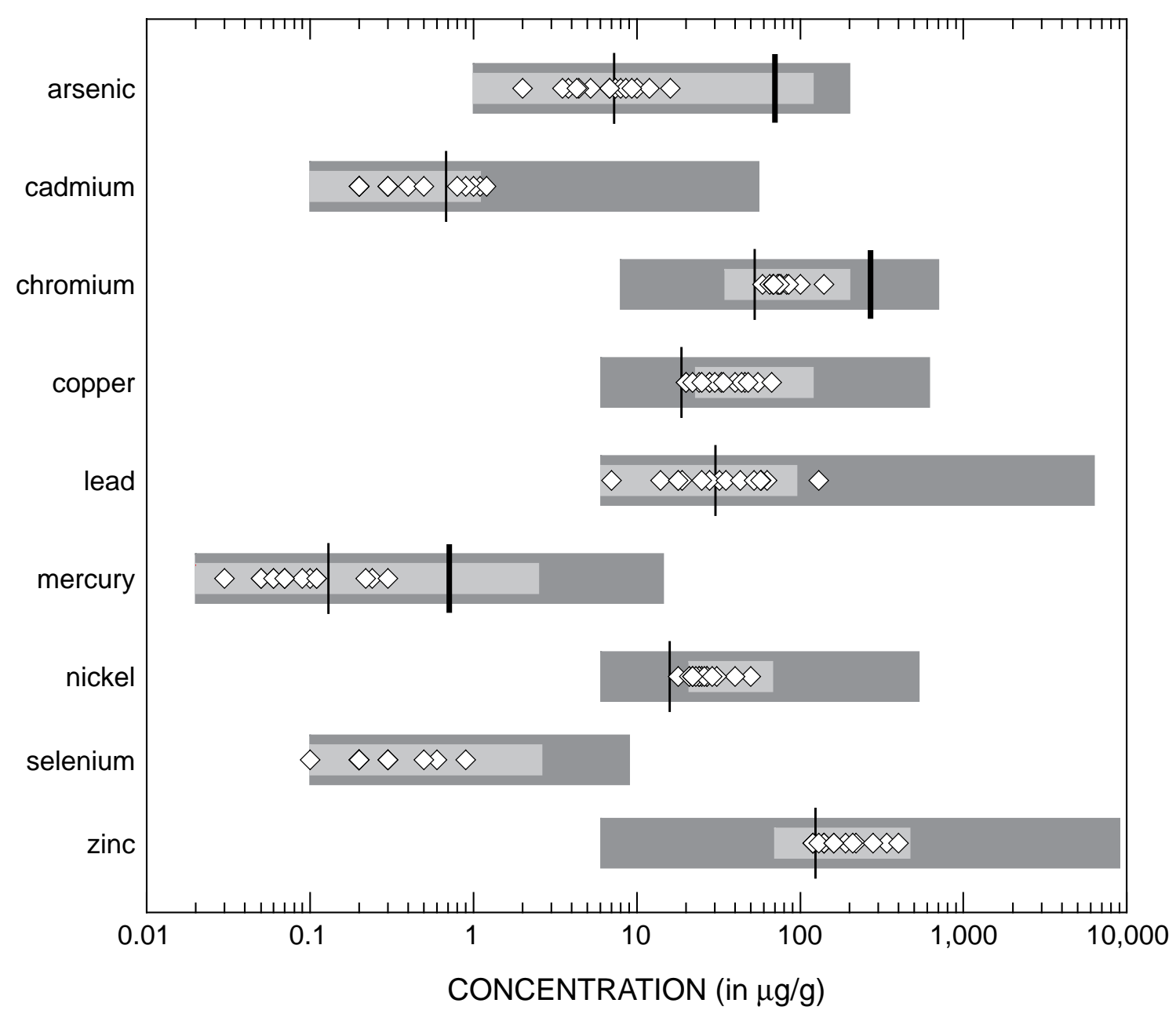

EXPLANATION USEPA Tier 2 screening value Detection in Tualatin Basin USEPA Tier 1 screening value

Figure 2. Comparison of concentrations of selected elements in bed sediment of the Tualatin River Basin with Willamette Basin concentrations, nationwide concentrations, and U.S. Environmental Protection Agency (USEPA) sediment quality screening values (USEPA, 1997). Elements are shown if national ranges were available. National ranges are from the first 20 study units of the National Water-Quality Assessment Program (Wentz, Bonn, and others, 1998). USEPA Tier 1 screening values for cadmium, copper, lead, nickel, and zinc are not shown on the figure because they require subtraction of the acid-volatile sulfide concentration. There are no USEPA screening values for selenium. 
Table 7. Summary statistics for organic chemical concentrations in bed sediment

[All concentrations in nanogram per gram dry weight (ng/g). Abbreviations: MDL, method detection limit; MRL, minimum reporting level; P25, 25th percentile; P75, 75th percentile; B95, 95th percentile of laboratory blanks. When MRL is given, detection frequency is number of detections/number of analyses; when MDL is given, detection frequency is number of detections greater than MDL/total number of detections/number of analyses. When a population statistic is not given, it is less than either the MRL or $2 \times \mathrm{MDL}$, and therefore indeterminate.]

\begin{tabular}{|c|c|c|c|c|c|c|}
\hline \multirow{2}{*}{ Organic chemical } & \multirow{2}{*}{$\begin{array}{l}\text { MDL [MRL] } \\
\quad(\mathrm{ng} / \mathrm{g})\end{array}$} & \multirow{2}{*}{$\begin{array}{l}\text { Detection } \\
\text { frequency }\end{array}$} & \multirow{2}{*}{$\underset{(\mathrm{ng} / \mathrm{g})}{\operatorname{Maximum}}$} & \multicolumn{3}{|c|}{ Population statistics (ng/g) } \\
\hline & & & & P25 & Median & P75 \\
\hline \multicolumn{7}{|l|}{ Organochlorine pesticides } \\
\hline cis-chlordane & [1.0] & $6 / 16$ & 9.8 & & & 1.8 \\
\hline trans-chlordane & [1.0] & $5 / 16$ & 8.6 & & & 1.4 \\
\hline dieldrin & [1.0] & $3 / 16$ & 6.5 & & & \\
\hline$o, p^{\prime}-\mathrm{DDE}$ & {$[1.0]$} & $2 / 16$ & 3.9 & & & \\
\hline$p, p^{\prime}-\mathrm{DDE}$ & {$[1.0]$} & $11 / 16$ & 10.0 & & 1.0 & 2.1 \\
\hline heptachlor epoxide & {$[1.0]$} & $1 / 16$ & 1.4 & & & \\
\hline cis-nonachlor & {$[1.0]$} & $4 / 16$ & 2.4 & & & 1.1 \\
\hline trans-nonachlor & {$[1.0]$} & $5 / 16$ & 7.8 & & & 1.5 \\
\hline
\end{tabular}

The following organochlorine pesticides were not detected in bed sediment: aldrin, chlorneb, dacthal, endosulfan I, endrin, $\alpha$-HCH, $\beta$-HCH, $\gamma$-HCH (lindane), heptachlor, isodrin, $o$, p'-methoxychlor, $p$, p'-methoxychlor, mirex, oxychlordane, cis-permethrin, trans-permethrin, toxaphene.

\section{PAHs (polyaromatic hydrocarbons)}

\begin{tabular}{|c|c|c|c|c|c|c|}
\hline acenaphthene & 31 & $0 / 4 / 15$ & 17 & & & \\
\hline acenaphthylene & 29 & $2 / 5 / 15$ & 38 & & & \\
\hline anthracene & 28 & $9 / 11 / 15$ & 130 & & & \\
\hline benz $[a]$ anthracene & 23 & $14 / 14 / 16$ & 480 & & 60 & 110 \\
\hline benzo $[a]$ pyrene & 19 & $9 / 9 / 16$ & 560 & & 54 & 120 \\
\hline benzo $[b]$ fluoranthene & 20 & $14 / 14 / 16$ & 680 & 53 & 72 & 120 \\
\hline benzo[ghi]perylene & 64 & $4 / 5 / 16$ & 470 & & & \\
\hline benzo $[k]$ fluoranthene & 33 & $14 / 14 / 16$ & 300 & & 80 & 140 \\
\hline chrysene & 24 & $14 / 14 / 16$ & 670 & 49 & 89 & 180 \\
\hline dibenz $[a, h]$ anthracene & 25 & $1 / 2 / 15$ & 35 & & & \\
\hline fluoranthene & 29 & $14 / 14 / 16$ & 890 & & 100 & 260 \\
\hline 9H-fluorene & 32 & $0 / 5 / 15$ & 29 & & & \\
\hline indeno[1,2,3-cd]pyrene & 25 & $10 / 10 / 16$ & 470 & & 61 & 82 \\
\hline naphthalene & 26 & $0 / 3 / 15$ & 25 & & & \\
\hline phenanthrene & 30 & $9 / 12 / 16$ & 250 & & & 150 \\
\hline pyrene & 27 & $14 / 14 / 16$ & 1100 & 59 & 110 & 250 \\
\hline
\end{tabular}

\section{Alkyl-PAHs}

$\begin{array}{llrr}\text { 1,2-dimethylnaphthalene } & 27 & 0 / 1 / 15 & \\ \text { 1,6-dimethylnaphthalene } & 28 & 0 / 1 / 15 & 11 \\ \text { 2,6-dimethylnaphthalene } & 26 & 10 / 13 / 15 & 12 \\ \text { 1-methylphenanthrene } & 30 & 3 / 6 / 15 & 53 \\ \text { 1-methylpyrene } & 25 & 4 / 6 / 15 & 70 \\ \text { 2-methylanthracene } & 25 & 1 / 1 / 15 & 89 \\ \text { 4,5-methylenephenanthrene } & 29 & 7 / 9 / 15 & 62\end{array}$

The following alkyl-PAHs were not detected in bed sediment: 2-ethylnaphthalene, 1-methyl-9H-fluorene, 2,3,6-trimethylnaphthalene. 
Table 7. Summary statistics for organic chemical concentrations in bed sediment-Continued

[All concentrations in nanogram per gram dry weight (ng/g). Abbreviations: MDL, method detection limit; MRL, minimum reporting level; P25, 25th percentile; P75, 75th percentile; B95, 95th percentile of laboratory blanks. When MRL is given, detection frequency is number of detections/number of analyses; when MDL is given, detection frequency is number of detections greater than MDL/total number of detections/number of analyses. When a population statistic is not given, it is less than either the MRL or $2 \times \mathrm{MDL}$, and therefore indeterminate.]

\begin{tabular}{|c|c|c|c|c|c|c|}
\hline \multirow{2}{*}{ Organic chemical } & \multirow{2}{*}{$\begin{array}{c}\text { MDL [MRL] } \\
(\mathrm{ng} / \mathrm{g})\end{array}$} & \multirow{2}{*}{$\begin{array}{l}\text { Detection } \\
\text { frequency }\end{array}$} & \multirow{2}{*}{$\begin{array}{c}\text { Maximum } \\
(\mathrm{ng} / \mathrm{g})\end{array}$} & \multicolumn{3}{|c|}{ Population statistics (ng/g) } \\
\hline & & & & P25 & Median & P75 \\
\hline \multicolumn{7}{|l|}{ Azaarines } \\
\hline acridine & 24 & $1 / 3 / 15$ & 37 & & & \\
\hline 2,2'-biquinoline & 50 & $2 / 2 / 15$ & 56 & & & \\
\hline 9H-carbazole & 28 & $1 / 4 / 15$ & 50 & & & \\
\hline isoquinoline & 28 & $1 / 1 / 15$ & 32 & & & \\
\hline phenanthridine & 26 & $2 / 2 / 15$ & 64 & & & \\
\hline quinoline & 30 & $0 / 1 / 15$ & 14 & & & \\
\hline \multicolumn{7}{|c|}{ The following azaarine was not detected in bed sediment: benzo[c]cinnoline. } \\
\hline \multicolumn{7}{|l|}{ Phthalates } \\
\hline * bis(2-ethylhexyl)phthalate $(\mathrm{B} 95=100)$ & 31 & $* 12 / 16$ & $* 9,900$ & $* 8$ & $* 140$ & $* 860$ \\
\hline * butylbenzylphthalate $(\mathrm{B} 95=64)$ & 27 & $* 12 / 16$ & $* 1,300$ & $* 1$ & $* 9$ & $* 94$ \\
\hline * diethylphthalate $(\mathrm{B} 95=25)$ & 31 & $* 1 / 15$ & $* 14$ & & & \\
\hline * di- $n$-butylphthalate $(\mathrm{B} 95=54)$ & 28 & $* 10 / 15$ & $* 36$ & & $* 16$ & $* 23$ \\
\hline di- $n$-octylphthalate & 25 & $9 / 9 / 16$ & 820 & & 72 & 97 \\
\hline \multicolumn{7}{|c|}{ The following phthalate was not detected in bed sediment: dimethylphthalate. } \\
\hline \multicolumn{7}{|l|}{$\underline{\text { Phenols }}$} \\
\hline$p$-cresol & 32 & $12 / 12 / 16$ & 880 & & & 155 \\
\hline 3,5-dimethylphenol & 31 & $1 / 1 / 15$ & 43 & & & \\
\hline * phenol (B95=27) & 20 & $* 2 / 15$ & $* 31$ & & & \\
\hline
\end{tabular}

\section{Chlorinated aromatic compounds}

The following chlorinated organic compounds were not detected in bed sediment: 2-chloronaphthalene, 1,2-dichlorobenzene, 1,3-dichlorobenzene, 1,4-dichlorobenzene, hexachlorobenzene, pentachloroanisole, pentachloronitrobenzene, total PCB, 1,2,4-trichlorobenzene.

\section{Other}

$\begin{array}{lllr}\text { anthraquinone } & 30 & 5 / 6 / 15 & 100 \\ \text { dibenzothiophene } & 28 & 1 / 4 / 15 & 31 \\ \text { N-nitrosodiphenylamine } & 27 & 1 / 2 / 15 & 28\end{array}$

The following other compounds were not detected in bed sediment: azobenzene, bis(2-chloroethoxy)methane, 4-bromophenyl-phenylether, 4-chlorophenyl-phenylether, 2,4-dinitrotoluene, isophorone, nitrobenzene, N-nitrosodi- $n$-propylamine.

*Blank contamination was common for this analyte (Lopes and others, 1998). Detection frequency is given as number of detections above 95 th percentile of laboratory blanks (B95). Maximum value and population statistics have been adjusted by subtracting the B95 value. 



Figure 3. Comparison of concentrations of selected organic compounds in bed sediment of the Tualatin River Basin with Willamette Basin concentrations, nationwide concentrations, and U.S. Environmental Protection Agency (USEPA) sediment quality screening values (USEPA, 1997). All organochlorine pesticides that were detected in this study are shown, except $0, p^{\prime}$-DDE for which national ranges are not available. Total chlordane is 

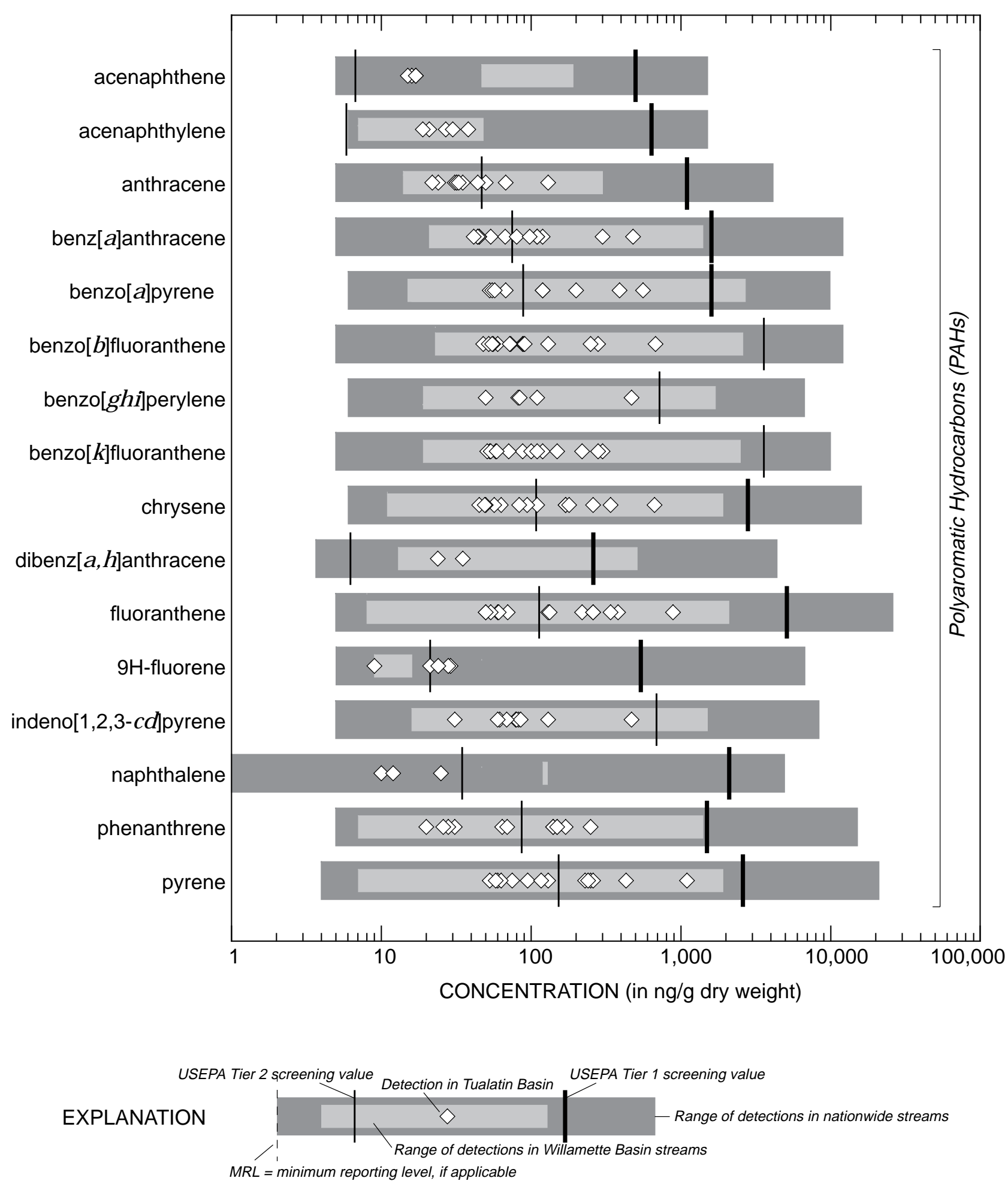

* Blank contamination was common for this analyte; values shown have been blank subtracted; jagged left edge indicates indeterminate lower limit.

the sum of cis-chlordane, trans- chlordane, cis-nonachlor, trans-nonachlor, and oxychlordane. Other organic compounds that were detected are shown if they were detected in at least half of the samples or if USEPA screening values apply. National ranges are from the first 20 study units of the National Water-Quality Assessment Program (Wentz, Bonn, and others, 1998). 
Table 8. Comparison of detection frequencies of polyaromatic hydrocarbons

[N is the number of samples. Willamette data from National Water Quality Assessment Program (Wentz, Bonn, and others, 1998). National data from Lopes and others (1998).]

\begin{tabular}{|c|c|c|c|}
\hline \multirow{2}{*}{$\begin{array}{l}\text { Polyaromatic } \\
\text { hydrocarbon }\end{array}$} & \multicolumn{3}{|c|}{ Detection frequency (percent) } \\
\hline & $\begin{array}{c}\text { Tualatin } \\
(\mathrm{N}=12)\end{array}$ & $\begin{array}{l}\text { Willamette } \\
(\mathrm{N}=27)\end{array}$ & $\begin{array}{c}\text { National } \\
(\mathrm{N}=370-433)\end{array}$ \\
\hline acenaphthene & 27 & 7 & 25 \\
\hline acenaphthylene & 33 & 19 & 34 \\
\hline anthracene & 73 & 30 & 44 \\
\hline benz $[a]$ anthracene & 88 & 33 & 50 \\
\hline benzo $[a]$ pyrene & 56 & 37 & 49 \\
\hline benzo $[b]$ fluoranthene & 88 & 37 & 56 \\
\hline benzo[ghi]perylene & 31 & 30 & 32 \\
\hline benzo $[k]$ fluoranthene & 88 & 37 & 55 \\
\hline
\end{tabular}

\begin{tabular}{lccc}
\hline \multirow{2}{*}{$\begin{array}{c}\text { Polyaromatic } \\
\text { hydrocarbon }\end{array}$} & \multicolumn{3}{c}{ Detection frequency (percent) } \\
\cline { 2 - 4 } & $\begin{array}{c}\text { Tualatin } \\
(\mathrm{N}=12)\end{array}$ & $\begin{array}{c}\text { Willamette } \\
(\mathrm{N}=27)\end{array}$ & $\begin{array}{c}\text { National } \\
(\mathrm{N}=370-433)\end{array}$ \\
\hline chrysene & 88 & 37 & 51 \\
dibenz[$[a, h]$ anthracene & 13 & 15 & 23 \\
fluoranthene & 88 & 56 & 65 \\
9H-fluorene & 33 & 15 & 31 \\
indeno[1,2,3-cd]pyrene & 56 & 33 & 39 \\
naphthalene & 20 & 4 & 18 \\
phenanthrene & 75 & 44 & 52 \\
pyrene & 88 & 52 & 62 \\
\hline
\end{tabular}

Table 9. Summary statistics for element concentrations in fish tissue

[Concentrations are in microgram per gram dry weight $(\mu \mathrm{g} / \mathrm{g})$. Abbreviations: P25, 25th percentile; P75, 75th percentile. Mean moisture content was 76.8\%. All fish were sculpin.]

\begin{tabular}{|c|c|c|c|c|c|}
\hline \multirow{2}{*}{ Element } & \multirow{2}{*}{$\begin{array}{l}\text { Detection } \\
\text { frequency }\end{array}$} & \multirow{2}{*}{$\begin{array}{l}\text { Maximum } \\
(\mu \mathrm{g} / \mathrm{g})\end{array}$} & \multicolumn{3}{|c|}{ Population statistics $(\mu \mathrm{g} / \mathrm{g})$} \\
\hline & & & P25 & Median & P75 \\
\hline aluminum & $10 / 10$ & 180 & 19 & 28 & 58 \\
\hline arsenic & $7 / 10$ & 0.4 & $<0.2$ & 0.2 & 0.3 \\
\hline barium & $10 / 10$ & 22 & 7.7 & 10 & 11 \\
\hline boron & $10 / 10$ & 3.5 & 0.8 & 1.2 & 2.6 \\
\hline chromium & $10 / 10$ & 2.0 & 1.7 & 1.9 & 1.9 \\
\hline cobalt & $10 / 10$ & 0.6 & 0.3 & 0.3 & 0.6 \\
\hline copper & $10 / 10$ & 3.8 & 2.0 & 2.8 & 3.4 \\
\hline iron & $10 / 10$ & 280 & 65 & 83 & 160 \\
\hline lead & $6 / 10$ & 0.9 & $<0.2$ & 0.3 & 0.7 \\
\hline manganese & $10 / 10$ & 78 & 15 & 28 & 40 \\
\hline mercury & $8 / 10$ & 1.0 & 0.1 & 0.3 & 0.5 \\
\hline nickel & $10 / 10$ & 3.7 & 0.4 & 0.6 & 2.0 \\
\hline selenium & $8 / 10$ & 2.5 & 1.1 & 1.5 & 1.9 \\
\hline strontium & $10 / 10$ & 120 & 80 & 88 & 110 \\
\hline vanadium & $10 / 10$ & 2.4 & 1.0 & 1.2 & 1.6 \\
\hline zinc & $10 / 10$ & 110 & 83 & 95 & 110 \\
\hline
\end{tabular}



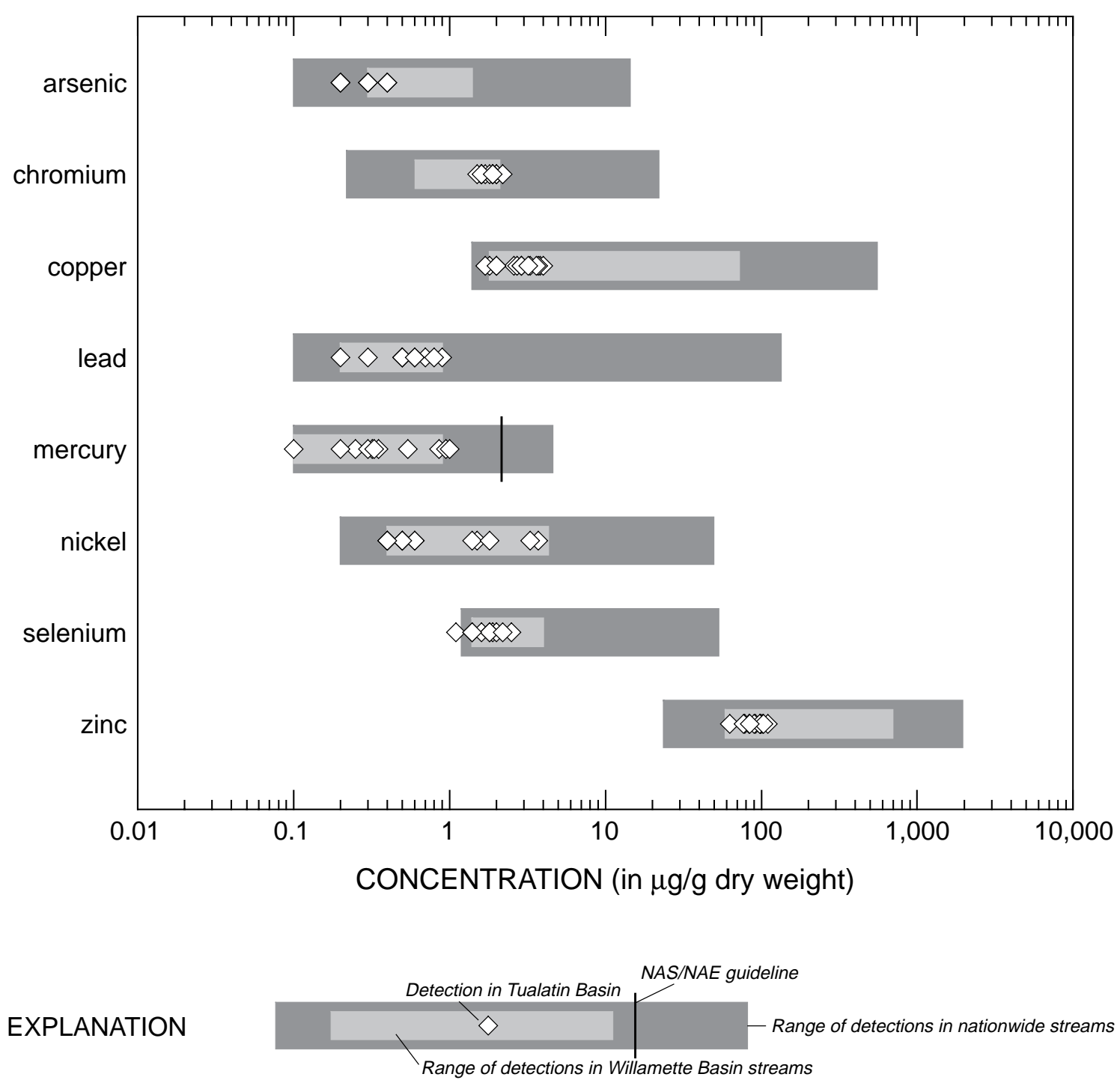

Figure 4. Comparison of concentrations of selected elements in fish tissue from the Tualatin River Basin with Willamette Basin concentrations, nationwide concentrations, and National Academy of Sciences/National Academy of Engineering (NAS/NAE) guidelines (NAS/NAE, 1973). Elements are shown if national ranges were available. National ranges are from the first 20 study units of the National Water-Quality Assessment Program (Wentz, Bonn, and others, 1998). The only NAS/NAE guideline for elements was for mercury. The guideline units were converted to dry weight by assuming a moisture content of $77 \%$, which was the average for fish sampled in this study. 
Table 10. Summary statistics for organochlorine concentrations in fish tissue.

[Concentrations are in nanogram per gram wet weight (ng/g wet wt). Abbreviations: P25, 25th percentile; P75, 75th percentile. P25, median, and P75 are given when detection frequencies are at least $75 \%, 50 \%$, and 25\%, respectively. Mean moisture content was $76.8 \%$. All fish were sculpin.]

\begin{tabular}{|c|c|c|c|c|c|}
\hline \multirow{2}{*}{ Element } & \multirow{2}{*}{$\begin{array}{l}\text { Detection } \\
\text { frequency }\end{array}$} & \multirow{2}{*}{$\begin{array}{c}\text { Maximum } \\
\text { (ng/g wet wt) }\end{array}$} & \multicolumn{3}{|c|}{ Population statistics (ng/g wet wt) } \\
\hline & & & P25 & Median & P75 \\
\hline \multicolumn{6}{|c|}{ Organochlorine pesticides } \\
\hline cis-chlordane & $8 / 12$ & 84 & & 13 & 26 \\
\hline trans-chlordane & $7 / 12$ & 25 & & 6.3 & 12 \\
\hline cis-nonachlor & $5 / 12$ & 14 & & & 8.9 \\
\hline trans-nonachlor & $10 / 12$ & 74 & 2.9 & 18 & 28 \\
\hline oxychlordane & $4 / 12$ & 35 & & & 8.6 \\
\hline total chlordane & $10 / 12$ & 210 & 10 & 38 & 67 \\
\hline dieldrin & $10 / 12$ & 86 & 6.8 & 14 & 20 \\
\hline$p, p$ '-DDD & $4 / 12$ & 24 & & & 5.8 \\
\hline$p, p$ '-DDE & $10 / 12$ & 21 & 7.5 & 14 & 18 \\
\hline$p, p^{\prime}-\mathrm{DDT}$ & $6 / 12$ & 8.6 & & 4.6 & 5.8 \\
\hline$\alpha-\mathrm{HCH}$ & $1 / 12$ & 6.6 & & & \\
\hline heptachlor epoxide & $4 / 12$ & 20 & & & 9.9 \\
\hline \multicolumn{6}{|c|}{ Other organochlorine compounds } \\
\hline total PCB & $8 / 12$ & 380 & & 75 & 120 \\
\hline pentachloroanisole & $6 / 12$ & 22 & & 4.0 & 7.2 \\
\hline
\end{tabular}

Table 11. Comparison of detection frequencies of organochlorine compounds in fish tissue.

[All Tualatin Basin fish samples were sculpin; fish species varied for Willamette Basin samples. $\mathrm{N}$ is the number of samples.]

\begin{tabular}{lcc}
\hline \multirow{2}{*}{ Organochlorine } & \multicolumn{2}{c}{ Detection frequency (percent) } \\
\cline { 2 - 3 } & Tualatin (N=12) & Willamette (N=19) \\
\hline total chlordane & 83 & 53 \\
dieldrin & 83 & 42 \\
$p, p$ '-DDE & 83 & 63 \\
$\alpha-\mathrm{HCH}$ & 8 & 0 \\
heptachlor epoxide & 33 & 0 \\
total PCB & 67 & 37 \\
pentachloroanisole & 50 & 11 \\
\hline
\end{tabular}



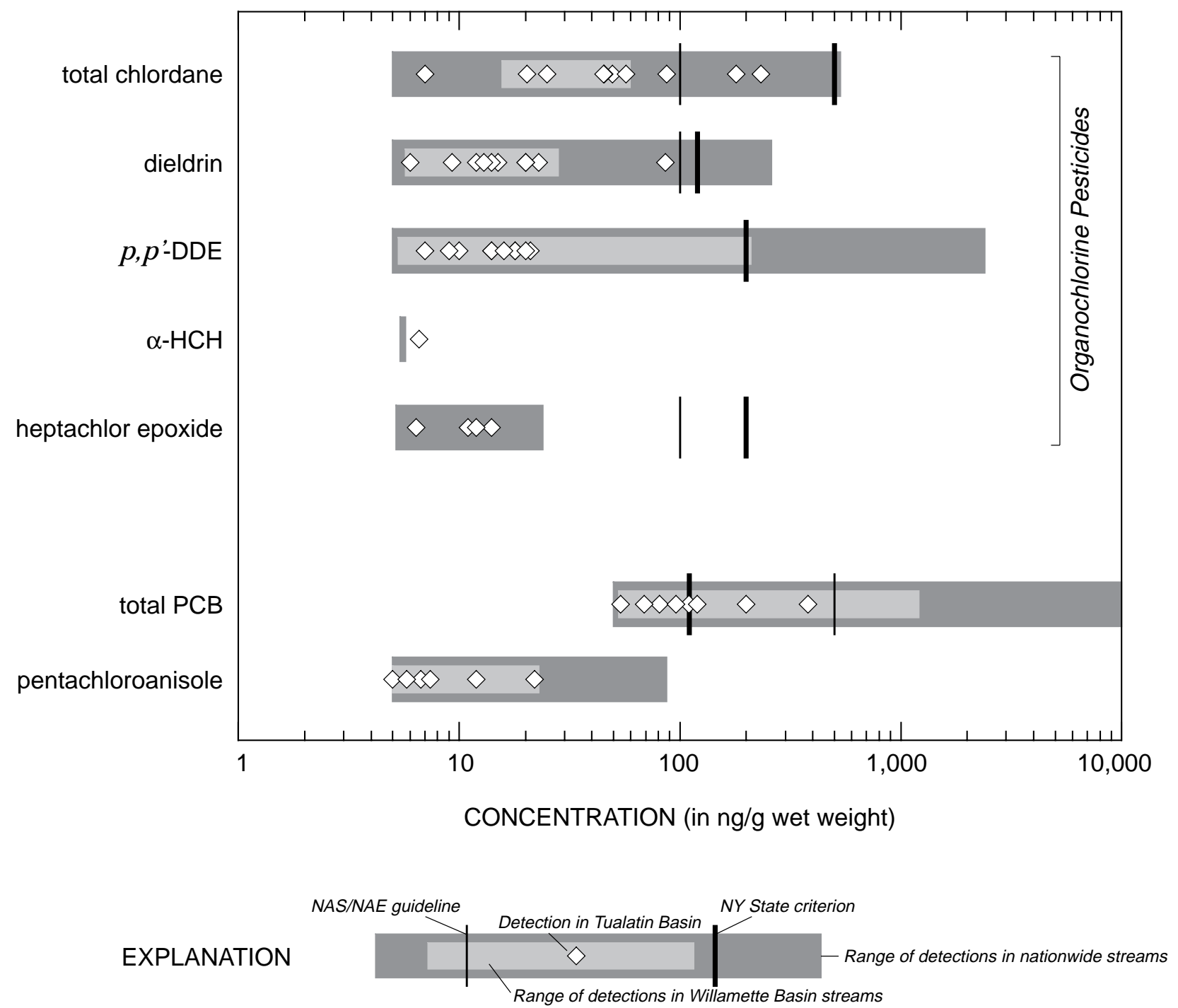

Figure 5. Comparison of concentrations of selected organochlorine compounds in fish tissue from the Tualatin River Basin with Willamette Basin concentrations, nationwide concentrations, National Academy of Sciences/ National Academy of Engineering (NAS/NAE) guidelines (NAS/NAE, 1973), and New York State criteria for fish in the Niagara River (Newell and others, 1987). All organic compounds that were detected in this study are shown, except p,p'-DDT and p.p'-DDD, for which national ranges were not available. Total chlordane is the sum of cischlordane, trans-chlordane, cis-nonachlor, trans-nonachlor, and oxychlordane. National ranges are from the first 20 study units of the National Water-Quality Assessment Program (Wentz, Bonn, and others, 1998). The compounds $\alpha-\mathrm{HCH}$ and heptachlor epoxide were not detected in Willamette Basin fish. 


\section{Comparisons between bed sediment and fish tissue}

Concentrations in bed sediment and fish tissue were compared for evidence of bioaccumulation and to determine if concentrations in one medium were a good predictor of concentrations in the other medium.

For most elements, concentrations in tissue were one to three orders of magnitude lower than those in sediment (fig. 6). Two exceptions were mercury and selenium. Even when their concentrations were normalized to organic carbon (sediment) and lipid (tissue), the tissue concentration exceeded the sediment concentration, an indication of bioaccumulation of these elements. This finding for mercury and selenium is not surprising because both elements have organometallic forms. Other elements, such as arsenic and lead, also form organometallic compounds, but these elements did not appear to accumulate in tissue. These observa- tions are consistent with those reported for the Willamette Basin (Wentz, Waite, and Rinella, 1998).

In contrast to the elements, tissue concentrations of organochlorines usually exceeded bed sediment concentrations by at least tenfold, indicating that bioaccumulation is likely (fig. 6). After normalization to organic carbon and lipid, tissue/sediment concentration ratios were still greater than 1, generally between 2 and 10.

Correlations between bed sediment and tissue concentrations were poor for most elements and weak for organochlorines (table 12). Normalizing to organic carbon and lipid did not significantly improve the correlations. However, graphical examination showed that such normalization slightly increased the linearity of the relation for the organochlorines. Even for the analytes that show the best correlations between tissue and sediment concentrations (lead and cis-chlordane), the

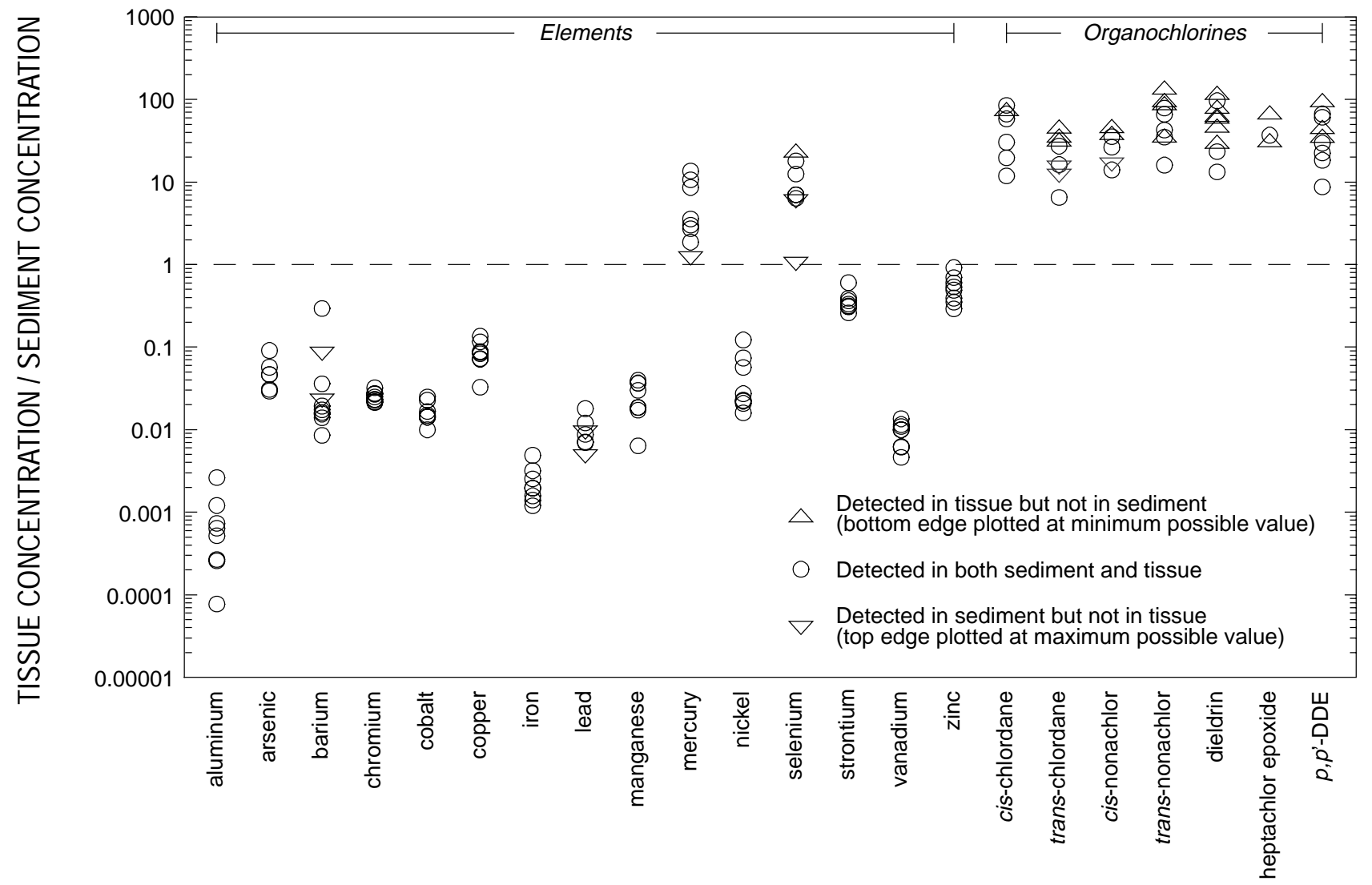

Figure 6. Ratio of concentrations in tissue to concentrations in sediment. Concentrations were in the same units, making the resulting ratio dimensionless. 
relation is not strong enough to be quantitatively predictive. Even simple detection was not well correlated for most organochlorines. Detection of an organochlorine in sediment was usually a good predictor of detection in tissue, but nondetection in sediment was not an accurate predictor of nondetection in tissue (table 13). Detection of organochlorines in tissue when they were not detected in sediment from the same site was common, but the reverse never occurred.

Table 12. Correlations between concentrations in sediment and tissue.

[Spearman correlation coefficients $(\rho)$ shown in boldface type are statistically significant at $\alpha=0.05 ; \rho=1.0$ or -1.0 indicates a perfect monotonic relation; $\rho=0$ indicates no relation. Normalized indicates that sediment and tissue concentrations were normalized to organic carbon and lipid content, respectively. $\mathrm{N}$ is the number of samples.]

\begin{tabular}{|c|c|c|c|}
\hline \multirow[t]{2}{*}{ Chemical } & \multirow[t]{2}{*}{$\mathbf{N}$} & \multicolumn{2}{|c|}{$\begin{array}{l}\text { Spearman correlation } \\
\text { coefficient }(\rho)\end{array}$} \\
\hline & & Original data & Normalized \\
\hline \multicolumn{4}{|l|}{ Elements } \\
\hline aluminum & 8 & 0.04 & 0.81 \\
\hline arsenic & 8 & 0.47 & 0.11 \\
\hline barium & 8 & 0.02 & -0.50 \\
\hline chromium & 8 & 0.04 & -0.07 \\
\hline cobalt & 8 & 0.87 & 0.64 \\
\hline copper & 8 & 0.13 & 0.00 \\
\hline iron & 8 & 0.71 & 0.86 \\
\hline lead & 8 & 0.85 & 0.88 \\
\hline manganese & 8 & 0.41 & 0.33 \\
\hline mercury & 8 & 0.29 & -0.50 \\
\hline nickel & 8 & 0.76 & 0.71 \\
\hline selenium & 8 & -0.44 & -0.50 \\
\hline strontium & 8 & 0.13 & 0.02 \\
\hline vanadium & 8 & 0.51 & 0.62 \\
\hline zinc & 8 & 0.12 & -0.33 \\
\hline \multicolumn{4}{|l|}{ Organochlorines } \\
\hline cis-chlordane & 10 & 0.78 & 0.83 \\
\hline trans-chlordane & 10 & 0.53 & 0.57 \\
\hline cis-nonachlor & 10 & 0.63 & 0.64 \\
\hline trans-nonachlor & 10 & 0.70 & 0.71 \\
\hline dieldrin & 10 & 0.59 & 0.65 \\
\hline heptachlor epoxide & 10 & 0.50 & 0.64 \\
\hline$p, p$ '-DDE & 10 & 0.70 & 0.59 \\
\hline
\end{tabular}

Table 13. Use of organochlorine detection in sediment as a predictor of organochlorine detection in tissue.

[Explanation: In column two, $3 / 5=60 \%$ indicates that the analyte was detected in sediment at 5 sites, 3 of which had also detection in tissue-a correct prediction rate of 60 percent. In column three, $1 / 4=25 \%$ indicates that the analyte was not detected in sediment at 4 sites, 1 of which had a detection in tissue - an incorrect prediction rate of 25 percent.]

\begin{tabular}{|c|c|c|}
\hline Analyte & $\begin{array}{c}\text { Detection in tissue } \\
\text { given } \\
\text { detection in } \\
\text { bed sediment }\end{array}$ & $\begin{array}{c}\text { Detection in tissue } \\
\text { given } \\
\text { nondetection in } \\
\text { bed sediment }\end{array}$ \\
\hline \multicolumn{3}{|c|}{ Organochlorine pesticides } \\
\hline cis-chlordane & $6 / 6=100 \%$ & $1 / 4=25 \%$ \\
\hline trans-chlordane & $3 / 5=60 \%$ & $3 / 5=60 \%$ \\
\hline cis-nonachlor & $3 / 4=75 \%$ & $2 / 6=33 \%$ \\
\hline trans-nonachlor & $5 / 5=100 \%$ & $4 / 5=80 \%$ \\
\hline oxychlordane & no detections in sediment & $3 / 10=30 \%$ \\
\hline dieldrin & $3 / 3=100 \%$ & $6 / 7=86 \%$ \\
\hline$p, p$ '-DDE & $6 / 6=100 \%$ & $3 / 4=75 \%$ \\
\hline$\alpha-\mathrm{HCH}$ & no detections in sediment & $1 / 10=10 \%$ \\
\hline heptachlor epoxide & $1 / 1=100 \%$ & $2 / 9=22 \%$ \\
\hline \multicolumn{3}{|c|}{ Other organochlorine compounds } \\
\hline $\mathrm{PCBs}$ & no detections in sediment & $7 / 10=70 \%$ \\
\hline pentachloroanisole & no detections in sediment & $6 / 10=60 \%$ \\
\hline
\end{tabular}

\section{Site-specific findings}

Beaverton Creek - High levels of organic contaminants distinguished the Beaverton Creek site from all other sites sampled in this study. This site was one of two that had an exceedance of a USEPA Tier 1 screening value (for bis(2-ethylhexyl)phthalate). USEPA Tier 2 screening values were exceeded for 21 chemicals, including various elements, organochlorine pesticides, PAHs, phthalates and phenols (table 14). Moreover, comparisons to screening values could not be made for a number of semivolatile compounds because chemical interferences compromised the analyses of the Beaverton Creek samples. It is likely that Tier 2 screening values would be exceeded for some of these compounds. The frequency of chemical interferences at this site was probably caused by the overall high concentration of contaminants. No other site yielded samples that had such extensive interference problems. The concentration of PCBs in fish tissue at this site exceeded the NAS/NAE guideline, but was not the highest value found in this study. 
Table 14. Exceedances of guidelines.

[Symbol meanings are as follows: - , exceeds US Environmental Protection Agency (USEPA) Tier 1 sediment guideline; $\bullet$, exceeds USEPA Tier 2 sediment guideline; $\boldsymbol{\Lambda}$, exceeds National Academy of Sciences/National Academy of Engineering or New York State criteria for fish tissue; —, not analyzed]

\section{Sediment}

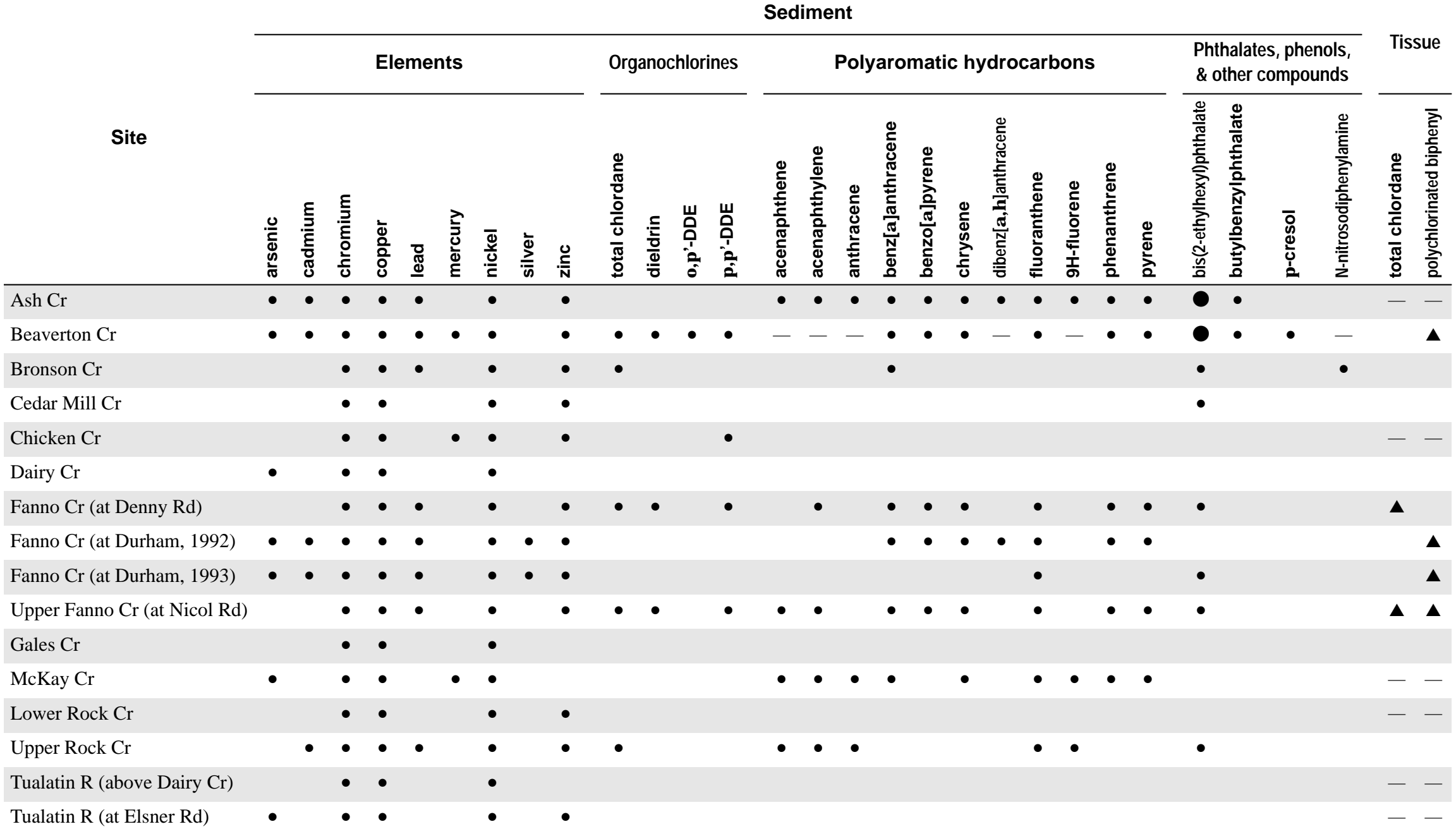

The following compounds were detected in sediment at least once, but concentrations never exceeded USEPA sediment guidelines: antimony, benzo[b]fluoranthene,

benzo[ghi]perylene, benzo[ $k]$ fluoranthene, indeno[1,2,3-cd]pyrene, naphthalene, diethylphthalate, di- $n$-butylphthalate, di- $n$-octylphthalate, phenol.

The following compounds have USEPA sediment guidelines, and were not detected in sediment: $\alpha-\mathrm{HCH}, \beta-\mathrm{HCH}, \gamma-\mathrm{HCH}$ (lindane), $p, p$ '-methoxychlor, toxaphene, dimethylphtha-

late, 1,2-dichlorobenzene, 1,3-dichlorobenzene, 1,4-dichlorobenzene, hexachlorobenzene, PCB (total), 1,2,4-trichlorobenzene, 4-bromophenyl-phenylether.

The following compounds were detected in tissue at least once, but concentrations never exceeded tissue criteria: dieldrin, $p, p$ '-DDE, heptachlor epoxide, pentachloroanisole.

The following compounds have tissue criteria, and were not detected in fish tissue: aldrin, endrin, heptachlor, mirex. 
The Beaverton Creek site was somewhat unusual in that the levels of all classes of contaminants were elevated. For the 22 organic compounds that could be compared among sites, the highest concentrations were found at the Beaverton Creek site in 18 cases. In nine of these, concentrations at the Beaverton Creek site exceeded the next highest value by a factor of two or more. The compounds included chlorinated pesticides, PAHs, phthalates, and $p$-cresol. The highest concentrations of lead and zinc found in this study were also from the Beaverton Creek site.

Biological effects were also evident at the Beaverton Creek site. Few fish were present. Although more than 300 feet of stream were sampled, only four sculpin were collected. Three-spine stickleback and redside shiner were present, about half of which had visible external abnormalities, primarily white tumors. This level of fish abnormality was unusually high compared to other sites in the Tualatin and Willamette River Basins (I.R. Waite, USGS, written commun., 1997).

Fanno Creek - The Fanno Creek sites (Nicol Road, Denny Road, Durham, and Ash Creek) provided an opportunity to follow contaminant patterns along a single urban stream. The Ash Creek site is located just above the confluence of Ash and Fanno Creeks. The land use along this stretch of Fanno Creek changes from mostly residential (Nicol Road site), to commercial (Ash Creek site) to light industrial (Durham site).

Concentrations of organochlorine pesticides in sediment were highest at the uppermost sites on Fanno Creek (Nicol Road and Denny Road) (fig. 7). Organochlorine contamination at these sites was second only to that found at Beaverton Creek, both in terms of total concentration and the variety of pesticides found.
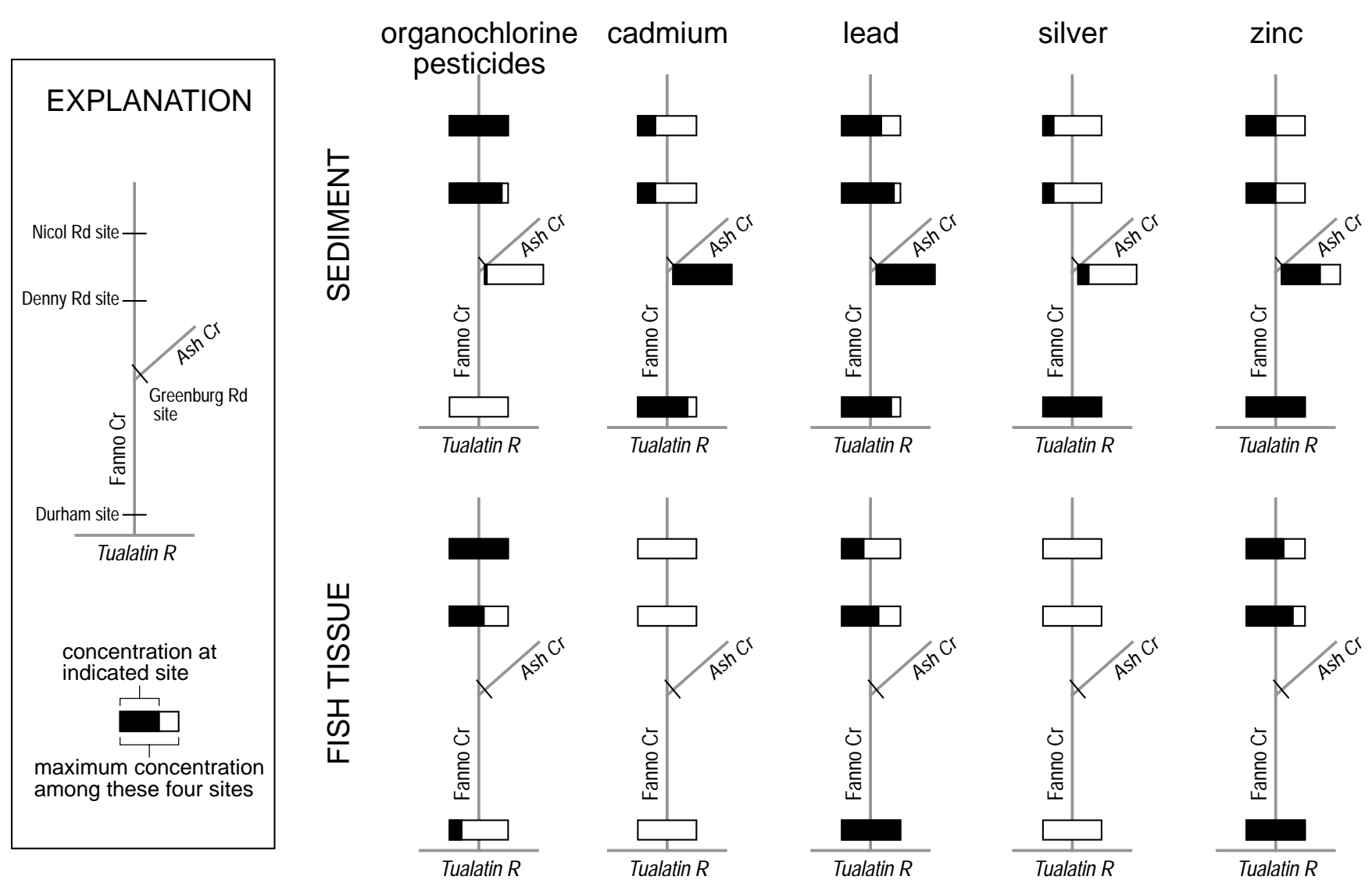

Figure 7. Variation in concentration of organochlorine pesticides and selected metals in the Fanno Creek system. Silver and cadmium were not detected in fish tissue at these sites. The Nicol Road site was sampled in 1992 for sediment and 1996 for fish; the Denny Road site was sampled in 1996 for both sediment and fish; the Greenburg Road site was sampled in 1992 for sediment only; the Durham site was sampled in 1992 and 1993 for both sediment and fish, the average is shown. 
Exceedances of USEPA Tier 2 screening values occurred at these two sites for total chlordane, dieldrin and $p, p$ '-DDE (table 14). In contrast, no organochlorines were detected at the Durham site in either 1992 or 1993. Only $p, p$ '-DDE was detected at Ash Creek, and the concentration was low-equal to the reporting limit.

For elements in sediment, the contaminant pattern was reversed-metals concentrations at the Durham site generally exceeded those found in the upstream sites. Silver concentrations at the Durham site were the highest found in this study, exceeding those found at Beaverton Creek by a factor of two. Cadmium and zinc concentrations were elevated at both the Durham site and the Ash Creek site. Lead concentrations, however, were relatively high throughout the Fanno Creek system. Tier 2 screening values for lead were exceeded at all of the Fanno Creek sites.

Contaminant patterns in fish tissue in the Fanno Creek system mimicked those found in sediment. Concentrations of organochlorine pesticides in fish tissue decreased upstream to downstream; metals concentrations (lead and zinc) increased upstream to downstream. Fish were much less abundant at the Nicol Road and Denny Road sites than at the Durham site. The lower fish abundance at the upper Fanno Creek sites may be related to stream size and habitat differences, but exposure to organochlorine pesticides could also be important.

Concentrations of organochlorine pesticides in fish tissue were particularly high at the Nicol Road and Denny Road sites. Total chlordane concentrations in fish tissue at these two sites were the highest found in this study-more than double the next highest concentration, which was found in Beaverton Creek fish tissue. These were the only two sites where the total chlordane concentration in fish tissue exceeded the NAS/NAE guideline. The dieldrin concentration found in Nicol Road fish tissue was $86 \mathrm{ng} / \mathrm{g}$ - more than three times the next highest concentration. The pesticide $\alpha-\mathrm{HCH}$, which was not found in the Willamette Basin study and found only once in the national study, was found at the Nicol Road site.

\section{Basinwide patterns}

Geologic pattern- Principal components analysis was applied to the element data (sediment only) to identify any patterns among sites. Most of the major elements strongly correlated with iron (table 15). The first principal component (PC1) accounts for 78 per- cent of the variability in the concentrations of the major elements. PC1 varies with the geologic characteristics of the Tualatin Basin (fig. 8).

Table 15. Correlations between concentrations of iron $(\mathrm{Fe})$ and other major elements in sediment.

[All are significant at $\alpha=0.05$, number of samples=16).]

\begin{tabular}{lcc}
\hline \multicolumn{1}{c}{ Element } & Spearman $(\rho)$ & Pearson $(\mathbf{r})$ \\
\hline aluminum $(\mathrm{Al})$ & 0.57 & 0.59 \\
calcium $(\mathrm{Ca})$ & 0.58 & 0.81 \\
magnesium $(\mathrm{Mg})$ & 0.75 & 0.91 \\
potassium $(\mathrm{K})$ & -0.90 & -0.95 \\
sodium $(\mathrm{Na})$ & -0.63 & -0.77 \\
titanium $(\mathrm{Ti})$ & 0.82 & 0.91 \\
\hline
\end{tabular}

Sites associated with Coast Range geology have more calcium, iron, magnesium, and titanium and less potassium and sodium than sites associated with the Tualatin or Chehalem Mountains. These differences are consistent with the fact that rocks of the Coast Range are older and more weathered than the others. Although the geologic pattern in the concentrations of major elements is striking, these elements are not usually of concern. However, many trace elements correlated well with PC1, suggesting that their concentrations are also strongly influenced by basin geology (fig. 9). This finding is particularly important for copper and nickel, which had concentrations exceeding USEPA Tier 2 screening values; it suggests that the levels of these elements can be attributed to the natural mineral matrix. The highest concentrations of copper and nickel occurred at sites dominated by Coast Range geology (Gales Creek and Tualatin River above Dairy Creek) which are also sites where only background levels are expected.

Urban pattern- Principal components analyses of a reduced data set revealed a pattern that is probably associated with urban influences. The reduced data set did not contain data for the major elements and their correlates (to eliminate the geologic pattern) or for Beaverton Creek (because of the large number of missing values from interferences). The first principal component, which accounted for about 30 percent of the variability, was dominated by PAHs (unsubstituted), with smaller contributions from lead and several phthalates. PAH concentrations in sediment have been shown to be higher in more urbanized areas (Kennicutt and others, 1994). 


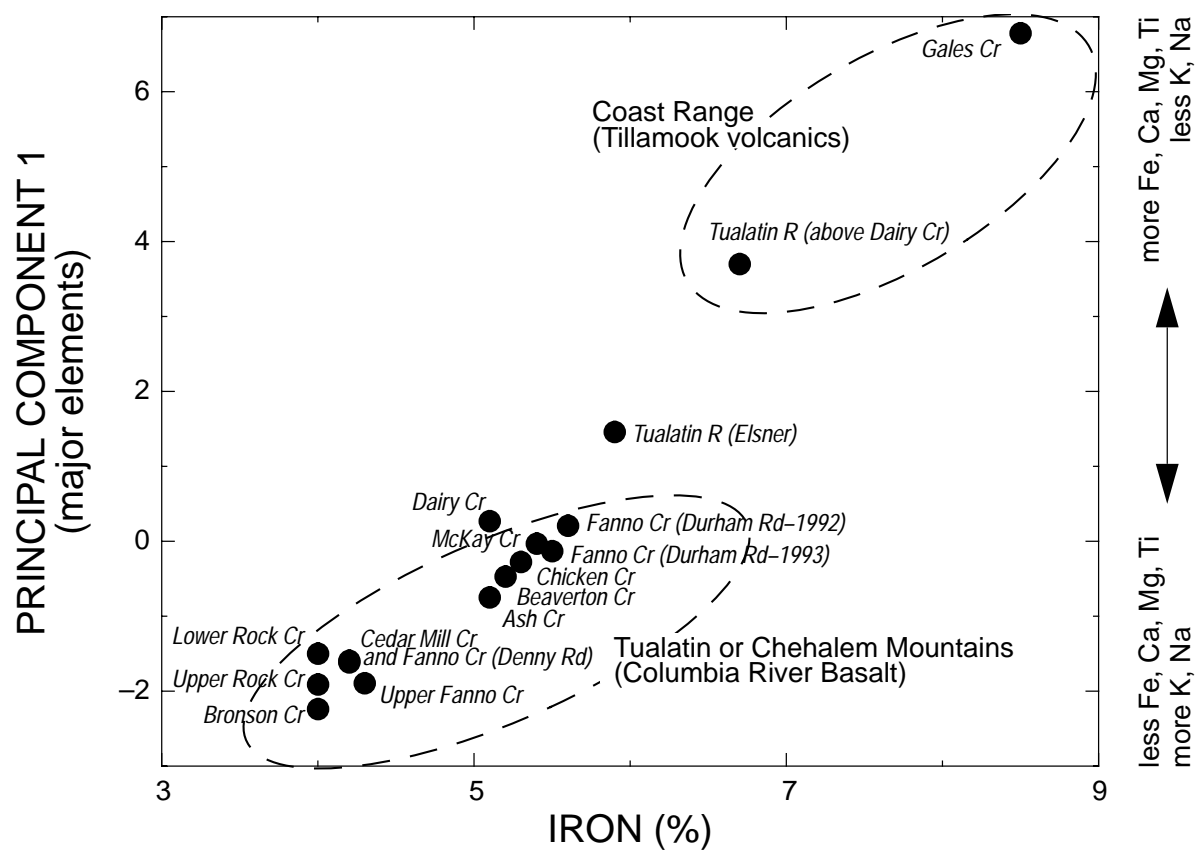

Figure 8. Principal component 1 (PC1) from analysis of bed sediment concentrations of major elements (aluminum, calcium, iron, magnesium, potassium, sodium, and titanium). PC1 accounts for 78 percent of the variability. Dotted enclosures indicate the highland drained by the stream and its underlying geologic formation (Wilson, 1997). Dairy Creek and the Tualatin River at Elsner Road drain highlands from both enclosed groups.
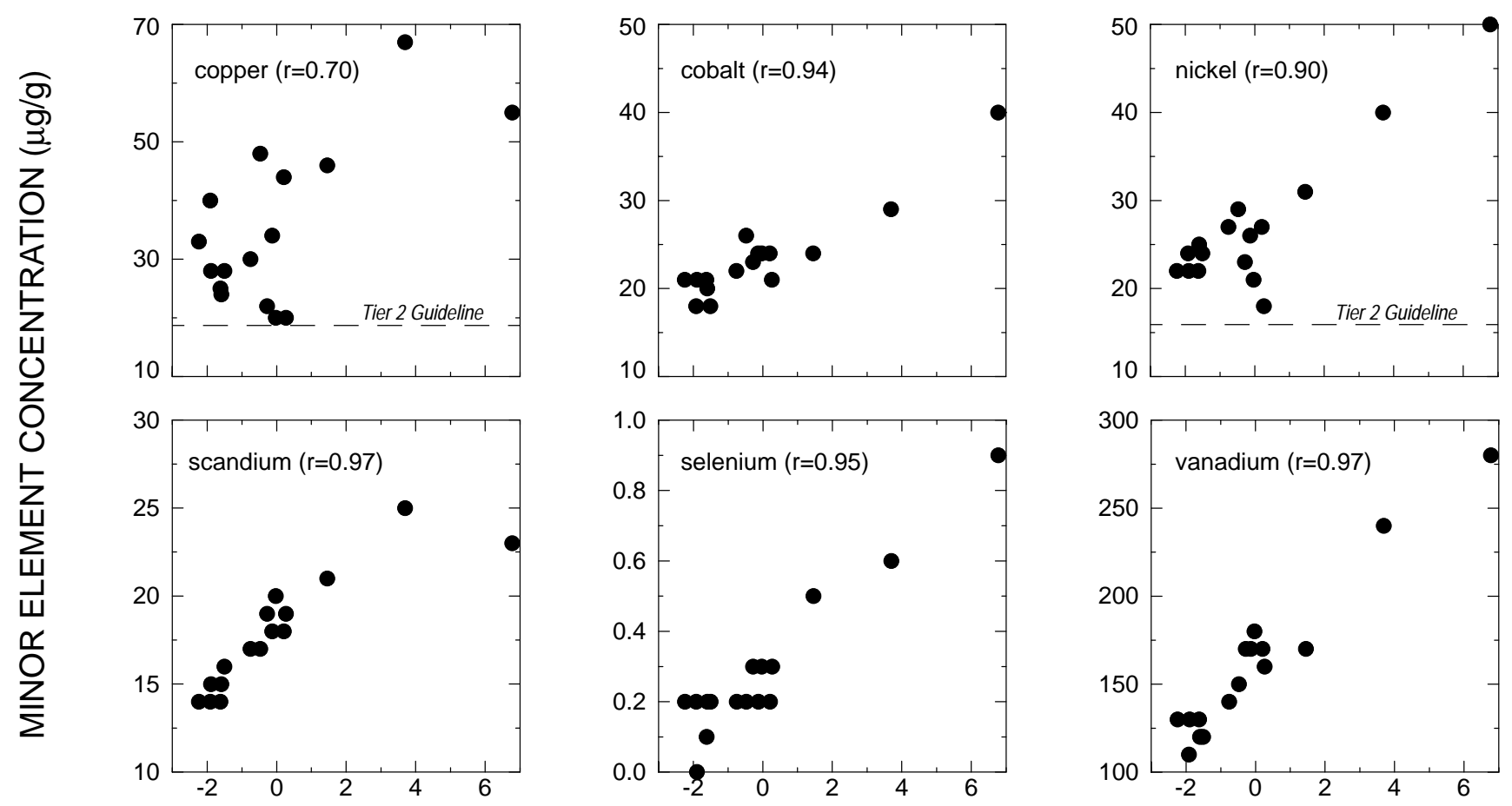

PRINCIPAL COMPONENT 1 (major elements)

Figure 9. Relation between bed sediment concentrations of selected minor elements and the principal component 1 of major elements (fig. 8). [All Pearson's correlation coefficients ( $r$ ) shown are statistically significant $(\alpha=0.01)$, number of samples $=16$.] 
The PAHs were highly correlated with one another; among the 12 PAHs that were detected at least 5 times, Spearman rank correlations $(\rho)$ were significant $(\alpha=0.01)$ for all 66 possible correlations and exceeded 0.7 for 51 correlations. Correlations of PAH concentrations with lead and phthalates were weaker, but still significant. Sites with the highest scores for PC1 were Ash Creek, Fanno Creek at Nicol Road, Fanno Creek at Denny Road, and McKay Creek. All of these sites had exceedances of USEPA Tier 2 screening values for numerous PAHs and for lead (table 14). In contrast, PAHs and phthalates were not detected at background sites (Gales Creek and Tualatin River above Dairy Creek); lead concentrations at these sites were the lowest found (undetected and $7 \mu \mathrm{g} / \mathrm{kg}$, respectively).

Sources of PAHs include combustion, road dust, and petroleum products. The type of PAH found can provide some indication of the most likely sources. Petroleum products generally contain significant amounts of alkyl-substituted PAHs, but combustion products do not (Hites and others, 1980). In this data set, alkylated PAHs contributed very little to PC1 and generally did not correlate well with the unsubstituted PAHs. This indicates that combustion products such as vehicle exhaust are a more important source of PAHs at these sites than are fuel spills or other releases of free petroleum. PAHs probably are transported to the sediments by atmospheric deposition or runoff of road dust. The strong correlation between total PAHs and lead ( $\rho=0.9, \alpha=0.01$ ) also supports the importance of vehicle exhaust as a source.

Although lead is associated with a general urban contamination pattern, other data indicate that it probably arises from at least one other source. Basinwide, lead correlated well with PAHs and with elements such as zinc, cadmium, and silver, but the correlations between PAHs and those three elements were much weaker. This indicates that a source exists that contributes lead and other trace elements, but not PAHs.

\section{Implications for monitoring and management}

Concentrations of chromium, copper, and nickel in bed sediment exceeded USEPA Tier 2 screening values at all sites tested, but exceedances of screening values could have resulted partially from sample processing procedures. Concentrations of trace elements are probably higher than they would have been had the sediment not been sieved at $63 \mu \mathrm{m}$. Analysis of unsieved sediment would provide a better comparison to the
USEPA screening values. An additional measurement, the acid-volatile sulfide concentration, would allow comparison to USEPA Tier 1 screening values for elements with low bioavailability, such as cadmium, copper, lead, nickel, and zinc. The most likely source of copper and nickel in the Tualatin River Basin is weathering of the native geologic material.

Contamination at the Beaverton Creek site was substantial. Additional monitoring would help determine the areal extent of the problem and assess potential sources. Chemicals of concern at this site included cadmium, lead, mercury, zinc, chlordanes, DDT and its metabolites, dieldrin, PAHs, phthalates, $p$-cresol, and PCBs. Given the observations made during this study concerning the low numbers of fish and the high incidence of tumors on the fish that were present, an assessment of the biological community and documentation of abnormalities could help determine if these problems are persistent or widespread.

Concentrations of organochlorine pesticides in the upper regions of Fanno Creek were some of the highest found in this study; levels of chlordanes, DDT metabolites, and dieldrin exceeded USEPA Tier 2 screening values. Concentrations in sediment at the downstream Durham Road site were substantially lower. Continued monitoring of Fanno Creek upstream of its confluence with Ash Creek to determine trends would indicate if organochlorine pesticide concentrations are slowly decreasing (as expected) or if a present-day source of these compounds is important. DDT use was banned by USEPA in 1972. Use of chlordanes and dieldrin, for termite control only, was permitted until 1988. It is possible that some homeowner use of these pesticides continues in this mostly residential area.

\section{ACKNOWLEDGMENTS}

The author thanks the following people for their contributions to this project. Kurt Carpenter, Clyde Doyle, Lauren Elmore, Stewart Rounds, and Ian Waite collected the fish tissue samples; Kurt Carpenter, Lauren Elmore, Valerie Kelly, Dennis Lynch, Richard Norris, and Ian Waite collected the bed sediment samples; the Willamette NAWQA project provided data for Fanno Creek and Gales Creek sites; Sara Ryker provided the ranges of the national data; Bruce Fisher, Lenny Orzol, and Mark Uhrich did the GIS work; Jan Miller, Frank Rinella, Stewart Rounds, John Williams, and Tammy Wood provided thoughtful reviews of this report. 


\section{REFERENCES CITED}

Briggs, P., 1990, Elemental analysis of geological materials by inductively coupled plasma-atomic emission spectrometry, in Arbogast, B.F., Quality assurance manual for the Branch of Geochemistry, U.S. Geological Survey: U.S. Geological Survey Open-File Report 90-668, p. 83-91.

Curry, K.J., 1990, Determination of total sulfur in geologic materials by combustion, in Arbogast, B.F., ed., Quality assurance manual for the Branch of Geochemistry, U.S. Geological Survey: U.S. Geological Survey Open-File Report 90-668, p. 131-135.

Davis, J.C., 1973, Statistics in data analysis and geology: New York, Wiley, $550 \mathrm{p}$.

Foreman, W.T., Connor, B.F., Furlong, E.T., Vaught, D.G., and Merten, L.M., 1995, Methods of analysis by the U.S. Geological Survey National Water Quality Laboratory-Determination of organochlorine pesticides and polychlorinated biphenyls in bottom sediment by dual capillary-column gas chromatography with electron-capture detection: U.S. Geological Survey OpenFile Report 95-140, 78 p.

Furlong, E.T., Vaught, D.G., Merten, L.M., Foreman, W.T., and Gates, P.M., 1996, Methods of analysis by the U.S. Geological Survey National Water Quality Laboratory-Determination of semivolatile organic compounds in bottom sediment by solvent extraction, gel permeation chromatographic fractionation, and capillary-column gas chromatography/mass spectrometry: U.S. Geological Survey Open-File Report 95-719, $67 \mathrm{p}$.

Helsel, D.R., and Hirsch, R.M., 1992, Statistical methods in water resources: Amsterdam, Elsevier, 522 p.

Hites, R.A., LaFlamme, R.E., and Windsor Jr., J.G., 1980, Polycyclic aromatic hydrocarbons in marine/aquatic sediments - their ubiquity, in Petrakis, L. and Weiss, F.T., eds., Petroleum in the Marine Environment, American Chemical Society, Advances in Chemistry Series 185, p. 289-311.

Hoffman, G.L., 1996, Methods of analysis by the U.S. Geological Survey National Water-Quality Laboratory-Preparation procedure for aquatic biological material determined for trace metals: U.S. Geological Survey Open-File Report 96-362, 42 p.

Jobling, S., Reynolds, T., White, R., Parker, M.G., and Sumpter, J.P., 1995, A variety of environmentally persistent chemicals, including some phthalate plasticizers, are weakly estrogenic: Environmental Health Perspectives, v. 103, no. 7, p. 582-587.
Joliffe, I.T., 1986, Principal component analysis: New York, Springer-Verlag, $259 \mathrm{p}$.

Kennicutt II, M.C., Wade, T.L., Presley, B.J., Requejo, A.G., Brooks, J.M., and Denoux, G.J., 1994, Sediment contaminants in Casco Bay, Maine-Inventories, sources, and potential for biological impact: Environmental Science and Technology, v. 28, no. 1, p. 1-15.

Leiker, T.J., Madsen, J.E., Deacon, J.R. and Foreman, W.T., 1995, Methods of analysis by the U.S. Geological Survey National Water Quality Laboratory-Determination of chlorinated pesticides in aquatic tissue by capillary-column gas chromatography with electroncapture detection: U.S.Geological Survey Open-File Report 94-710, 42 p.

Lopes, T.J., Furlong, E.T., and Pritt, J.W., 1998, Occurrence and distribution of semivolatile organic compounds in stream bed sediments, United States, 1992-95, in Little, E.E., DeLonay, A.J., and Greenberg, B.M., eds., Environmental Toxicology and Risk Assessment-7th Volume, American Society for Testing and Materials, ASTM STP 1333, p. 105-119.

McKown, D.M., and Knight, R.J., 1990, Determination of uranium and thorium in geologic materials by delayed neutron counting, in Arbogast, B.F., ed., Quality assurance manual for the Branch of Geochemistry, U.S. Geological Survey: U.S. Geological Survey Open-File Report 90-668, p. 146-150.

National Academy of Sciences and National Academy of Engineering, 1973, Water quality criteria: Washington, D.C., U.S. Government Printing Office, 594 p.

Newell, A.J., Johnson, D.W., and Allen, L.K., 1987, Niagara River biota contamination project-Fish criteria for piscivorous wildlife: New York State Department of Environmental Conservation, Technical Report 87-3, $183 \mathrm{p}$.

Nriagu, J.O., and Pacyna, J.M., 1998, Quantitative assessment of worldwide contamination of air, water and soils by trace metals: Nature, v. 333, p. 134-139.

O'Leary, R.M., Crock, J.G., and Kennedy, K.R., 1990, Determination of mercury in geologic materials by continuous flow-cold vapor-atomic absorption spectroscopy, in Arbogast, B.F., ed., Quality assurance manual for the Branch of Geochemistry, U.S. Geological Survey: U.S. Geological Survey Open-File Report 90-668, p. 60-67.

O'Leary, R.M., and Viets, J.G., 1986, Determination of antimony, arsenic, bismuth, cadmium, copper, lead, molybdenum, silver, and zinc in geological materials by atomic absorption spectrometry using a hydrochloric acid-hydrogen peroxide digestion: Atomic Spectroscopy, v. 7, p 4-8. 
Prahl, F.G., Crecellus, E., and Carpenter, R., 1984, Polycyclic aromatic hydrocarbons in Washington coastal sediments-An evaluation of atmospheric and riverine routes of introduction: Environmental Science and Technology, v. 18, no. 9, p. 687-693.

SAS Institute, 1989, SAS/STAT ${ }^{\circledR}$, User's guide, version 6, (4th ed.) vol. 2: Cary, North Carolina, SAS Institute, $846 \mathrm{p}$.

Shelton, L.R., and Capel, P.D., 1994, Guidelines for collecting and processing samples of stream bed sediment for analysis of trace elements and organic contaminants for the National Water-Quality Assessment Program: U.S. Geological Survey Open-File Report 94-458, 20 p.

U.S. Environmental Protection Agency, 1997, The incidence and severity of sediment contamination in surface waters of the United States-Volume 1-National sediment quality survey: EPA/823/R-97/006, [variously paged].

Wakeham, S.G., Schaffner, C., and Giger, W., 1980, Polycyclic aromatic hydrocarbons in recent lake sediments-I. Compounds having anthropogenic origins: Geochimica Cosmochimica Acta, v. 44, p. 403-413.
Welsch, E.P., Crock, J.G., Sanzolone, R., 1990, Trace-level determination of arsenic and selenium using continuous-flow hydride generation atomic absorption spectrophotometry (HG-AAS), in Arbogast, B.F., Quality assurance manual for the Branch of Geochemistry, U.S. Geological Survey: U.S. Geological Survey Open-File Report 90-668, p. 38-45.

Wentz, D.A., Bonn, B.A., Carpenter, K.D., Hinkle, S.R., Janet, M.L., Rinella, F.A., Uhrich, M.A., Waite, I.R., Laenen, A., and Bencala, K.E., 1998, Water quality in the Willamette Basin, Oregon, 1991-95: U.S. Geological Survey Circular 1161, 34 p.

Wentz, D.A., Waite, I.R., and Rinella, F.A., 1998, Comparison of streambed sediment and aquatic biota as media for characterizing trace elements and organochlorine compounds in the Willamette Basin, Oregon: Environmental Monitoring and Assessment, v. 51, p 673-693.

Wilson, D.C., 1997, Geomorphology of the Tualatin valley, chap. 8 of Post-middle Miocene geologic history of the Tualatin Basin, Oregon with hydrogeologic implications: Portland, Portland State University, Ph.D. dissertation, p. 231-264. 
APPENDICES 

Appendix A. Explanation of statistical comparison of replicate ranges.

Comparisons of the variability of chemical analyses among sites is complicated because the magnitude of the concentration differs among analytes. Because of this, ranks of concentration ranges, rather than absolute ranges, were compared. Only compounds that were detected in all replicate samples were considered. Replicate ranges for the organic compounds and their corresponding ranks among sites are given in table A-1. Data for elements was treated identically, but the replicate ranges are not shown here.
Sites were compared by performing a Tukey multiple comparisons test on the ranks of the replicate ranges (Helsel and Hirsch, 1992; SAS Institute, 1989). In this test, the mean rank for each site is computed, then the mean ranks are tested to determine if there are any significant differences among them. If the mean ranks of two groups are not significantly different, they are assigned the same letter. Groups with significantly different mean ranks are assigned different letters. The results for the organic compounds and the elements are summarized in table A-2.

Table A-1. Range (maximum value minus minimum value) of values for each replicate set.

[Value in brackets is the rank of the replicate range among sites; each analyte is ranked separately.]

\begin{tabular}{|c|c|c|c|c|}
\hline \multirow{2}{*}{ Organic compound } & \multicolumn{4}{|c|}{ Range of replicate values [Rank among sites] } \\
\hline & Beaverton $\mathrm{Cr}$ & Fanno $\mathrm{Cr}$ at Denny $\mathrm{Rd}$ & Lower Rock Cr & Fanno $\mathrm{Cr}$ at Durham $\mathrm{Rd}$ \\
\hline pyrene & $100[3]$ & $30[2]$ & $14[1]$ & $218[4]$ \\
\hline benzo[k]fluoranthene & $50 \quad[3]$ & $0[1]$ & $7[2]$ & $131[4]$ \\
\hline phenanthrene & $50[3]$ & $20[2]$ & $14[1]$ & $133[4]$ \\
\hline butylbenzylphthalate & $80[3]$ & $17[2]$ & $3[1]$ & $738[4]$ \\
\hline bis(2-ethylhexyl)phthalate & $0[1]$ & $100[3]$ & $10[2]$ & $1057[4]$ \\
\hline benz[a]anthracene & $40[3]$ & $2[1]$ & $9[2]$ & $87[4]$ \\
\hline benzo[b]fluoranthene & $60[3]$ & $9[2]$ & $7[1]$ & $130[4]$ \\
\hline fluoranthene & $70[3]$ & $20[2]$ & $19[1]$ & $270[4]$ \\
\hline
\end{tabular}

Table A-2. Mean rank of replicate ranges.

[Values in parentheses identify groups that are significantly different $(\alpha=0.05$, Tukey test). Only analytes that were quantified for all samples in each replicate set were used in this analysis. Group A denotes the site with the largest variability and group C denotes the least variability.]

\begin{tabular}{lccccc}
\hline & $\mathbf{N}$ & Beaverton Cr & Fanno Cr at Denny Rd & Lower Rock Cr & Fanno Cr at Durham Rd \\
\hline Organic compounds & 8 & $2.8(\mathrm{~B})$ & $1.9(\mathrm{C})$ & $1.4(\mathrm{C})$ & $4.0(\mathrm{~A})$ \\
Elements & 36 & $1.8(\mathrm{C})$ & $2.1(\mathrm{C})$ & $2.8(\mathrm{~B})$ & $3.4(\mathrm{~A})$ \\
\hline
\end{tabular}


Appendix B. Bed sediment data

\begin{tabular}{|c|c|c|c|c|c|c|c|}
\hline $\begin{array}{c}\text { Site } \\
\text { abbrev }\end{array}$ & USGS station name & Date & Time $^{a}$ & Code $^{b}$ & $\begin{array}{l}\text { USGS } \\
\text { station }\end{array}$ & $\begin{array}{l}\text { Latitude } \\
\text { (degrees) }\end{array}$ & $\begin{array}{l}\text { Longitude } \\
\text { (degrees) }\end{array}$ \\
\hline Pcode & \multicolumn{7}{|l|}{ parameter code for this constituent in USGS database } \\
\hline Units & \multicolumn{7}{|l|}{ concentration units for chemical constituents } \\
\hline MRL & \multicolumn{7}{|c|}{ minimum reporting level: minimum value reported for this constituent by the laboratory } \\
\hline MDL & \multicolumn{7}{|c|}{ method detection limit: statistic associated with $1 \%$ chance of a false positive; $2 \times M D L$ is associated with $1 \%$ chance of false negative } \\
\hline Reprod & \multicolumn{7}{|c|}{ estimate of reproducibility: maximum replicate range for this analyte in this study } \\
\hline Ash & Ash Creek at Greenberg Road & 9-14-1992 & 10:00 & $\mathrm{P}$ & 14206930 & 452627 & 1224641 \\
\hline Bvtn & Beaverton Creek at Cedar Hills Blvd & 8-29-1996 & $11: 25$ & $\mathrm{P}$ & 452937122483400 & 452937 & 1224834 \\
\hline Bvtn-r & same & same & $11: 26$ & $\mathrm{R}$ & same & same & same \\
\hline Bronson & Bronson Creek at Walker Road & 9-16-1992 & $10: 30$ & $\mathrm{P}$ & 14206300 & 453149 & 1225218 \\
\hline Cedar & Cedar Mill Creek at mouth & 9-18-1992 & $10: 30$ & $\mathrm{P}$ & 14206311 & 453002 & 1225003 \\
\hline Chicken & Chicken Creek near Sherwood, OR & 9-18-1992 & $12: 00$ & $P$ & 14206750 & 452230 & 1225057 \\
\hline Dairy & Dairy Creek at Susbauer Road & $9-15-1992$ & $10: 00$ & $P$ & 14205850 & 453220 & 1230226 \\
\hline FanDen & Fanno Creek near Denny Road & 8-29-1996 & $9: 40$ & $\mathrm{P}$ & 452807122471400 & 452807 & 1224714 \\
\hline FanDen-r & same & same & $9: 41$ & $\mathrm{R}$ & same & same & same \\
\hline Fan-92 & Fanno Creek at Durham, OR & $9-1-1992$ & $15: 00$ & $\mathrm{P}$ & 14206950 & 452413 & 1224513 \\
\hline Fan-93a & same & $10-1-1993$ & 9:00 & $\mathrm{L}$ & same & same & same \\
\hline Fan-93b & same & same & $10: 00$ & $\mathrm{~L}$ & same & same & same \\
\hline Fan-93c & same & same & $10: 30$ & $\mathrm{~L}$ & same & same & same \\
\hline UpFan & Upper Fanno Creek at Nicol Road & 9-14-1992 & $11: 30$ & $\mathrm{P}$ & 14206920 & 452822 & 1224544 \\
\hline Gales & Gales Creek near Glenwood, OR & 9-9-1992 & $10: 30$ & $\mathrm{P}$ & 14203750 & 453837 & 1232209 \\
\hline McKay & McKay Creek at Hornecker Road & $9-15-1992$ & $12: 00$ & $\mathrm{P}$ & 14206120 & 453235 & 1230010 \\
\hline LoRock & Lower Rock Creek at Brookwood Road & $9-17-1992$ & $12: 00$ & $\mathrm{P}$ & 14206448 & 453030 & 1225557 \\
\hline LoRock-a & same & same & 11:00 & $\mathrm{C}$ & same & same & same \\
\hline LoRock-b & same & same & $11: 30$ & $\mathrm{C}$ & same & same & same \\
\hline UpRock & Upper Rock Creek at Baseline Road & 9-16-1992 & $12: 00$ & $P$ & 14206447 & 453114 & 1225444 \\
\hline UpTual & Tualatin River above Dairy Creek & 9-22-1992 & $12: 00$ & $\mathrm{P}$ & 14204895 & 453002 & 1225948 \\
\hline Tual-Els & Tualatin River at Elsner Rd near Sherwood, OR & $9-21-1992$ & 12:00 & $\mathrm{P}$ & 14206740 & 452318 & 1225102 \\
\hline
\end{tabular}


Appendix B. Bed sediment data—continued

[Abbreviations: mm, millimeters; $\mu \mathrm{m}$, micrometers; mg/g, milligram per gram; $\mu \mathrm{g} / \mathrm{g}$, microgram per gram; ng/g, nanogram per gram; ND, not detected; I, interference; E, estimated value; - , no value]

\begin{tabular}{|c|c|c|c|c|c|c|c|c|c|c|}
\hline $\begin{array}{l}\text { Site } \\
\text { abbrev }\end{array}$ & $\begin{array}{l}\text { Organic } \\
\text { carbon } \\
(<2 \mathrm{~mm})\end{array}$ & $\begin{array}{l}\text { Organic } \\
\text { carbon } \\
(<63 \mu \mathrm{m})\end{array}$ & $\begin{array}{c}\text { Fraction } \\
\text { finer than } \\
63 \mu \mathrm{m}\end{array}$ & Aluminum & Calcium & Iron & Magnesium & Phosphorus & Potassium & Sodium \\
\hline P-Code & 49271 & 49266 & 80164 & 34790 & 34830 & 34880 & 34900 & 34935 & 34940 & 34960 \\
\hline Units & percent & percent & percent & $\mathrm{mg} / \mathrm{g}$ & $\mathrm{mg} / \mathrm{g}$ & $\mathrm{mg} / \mathrm{g}$ & $\mathrm{mg} / \mathrm{g}$ & $\mathrm{mg} / \mathrm{g}$ & $\mathrm{mg} / \mathrm{g}$ & $\mathrm{mg} / \mathrm{g}$ \\
\hline MRL & 0.02 & 0.01 & - & 0.05 & 0.05 & 0.05 & 0.05 & 0.05 & 0.5 & 0.05 \\
\hline MDL & - & - & - & - & - & - & - & - & - & - \\
\hline Reprod & 0.2 & 0.16 & 7 & 3 & $<1$ & 1 & 0.3 & 0.3 & 1 & $<1$ \\
\hline Ash & 3.0 & 2.62 & 79 & 73 & 14 & 51 & 7.4 & 1.8 & 14 & 14 \\
\hline Bvtn & 4.1 & 3.91 & 81 & 68 & 17 & 52 & 8.3 & 1.8 & 13 & 14 \\
\hline Bvtn-r & 4.2 & 3.86 & - & 68 & 17 & 52 & 8.2 & 1.9 & 12 & 14 \\
\hline Bronson & 3.2 & 2.36 & 82 & 65 & 13 & 40 & 6.8 & 1.1 & 15 & 15 \\
\hline Cedar & 2.0 & 1.81 & 71 & 73 & 13 & 42 & 7.2 & 1.1 & 15 & 15 \\
\hline Chicken & 2.3 & 2.24 & 53 & 72 & 12 & 53 & 7.3 & 1.4 & 14 & 12 \\
\hline Dairy & 3.0 & 2.60 & 33 & 76 & 11 & 51 & 7.5 & 1.2 & 13 & 10 \\
\hline FanDen & 1.9 & 1.61 & 78 & 65 & 16 & 42 & 6.5 & 0.9 & 13 & 16 \\
\hline FanDen-r & 2.0 & 1.54 & - & 65 & 16 & 42 & 6.5 & 0.6 & 13 & 16 \\
\hline Fan-92 & 1.5 & 3.15 & 24 & 69 & 18 & 56 & 8.9 & 2.0 & 12 & 14 \\
\hline Fan-93a & 1.0 & 2.91 & 20 & 68 & 18 & 55 & 8.4 & 1.8 & 12 & 14 \\
\hline Fan-93b & 1.3 & 2.69 & 27 & 68 & 18 & 55 & 8.1 & 1.9 & 13 & 14 \\
\hline Fan-93c & 1.7 & 2.28 & 45 & 71 & 21 & 61 & 9.1 & 1.5 & 12 & 15 \\
\hline UpFan & 2.3 & 1.74 & 76 & 67 & 14 & 43 & 6.6 & 1.2 & 15 & 16 \\
\hline Gales & 0.82 & 5.73 & 7 & 75 & 26 & 85 & 22 & 1.8 & 7.7 & 9.1 \\
\hline McKay & 2.1 & 2.76 & 28 & 71 & 13 & 54 & 6.8 & 1.4 & 13 & 12 \\
\hline LoRock & 2.6 & 1.87 & 53 & 73 & 14 & 41 & 7.6 & 1.1 & 15 & 14 \\
\hline LoRock-a & 2.5 & 1.71 & 54 & 70 & 14 & 40 & 7.3 & 1.0 & 15 & 14 \\
\hline LoRock-b & 2.7 & 1.89 & 47 & 70 & 14 & 41 & 7.4 & 1.1 & 15 & 14 \\
\hline UpRock & 3.2 & 1.95 & 69 & 66 & 14 & 40 & 6.9 & 1.2 & 15 & 14 \\
\hline UpTual & 1.5 & 2.04 & 34 & 78 & 20 & 67 & 15 & 1.3 & 9.9 & 11 \\
\hline Tual-Els & 2.1 & 2.90 & 47 & 76 & 16 & 59 & 10 & 2.0 & 12 & 11 \\
\hline
\end{tabular}


Appendix B. Bed sediment data—continued

[Abbreviations: mg/g, milligram per gram; $\mu \mathrm{g} / \mathrm{g}$, microgram per gram; ng/g, nanogram per gram; ND, not detected; I, interference; E, estimated value; —, no value]

\begin{tabular}{|c|c|c|c|c|c|c|c|c|c|c|}
\hline $\begin{array}{c}\text { Site } \\
\text { abbrev }\end{array}$ & Sulfur & Titanium & Antimony & Arsenic & Barium & Beryllium & Bismuth & Cadmium & Cerium & Chromium \\
\hline P-Code & 34970 & 49274 & 34795 & 34800 & 34805 & 34810 & 34816 & 34825 & 34835 & 34840 \\
\hline Units & $\mathrm{mg} / \mathrm{g}$ & $\mathrm{mg} / \mathrm{g}$ & $\mu \mathrm{g} / \mathrm{g}$ & $\mu \mathrm{g} / \mathrm{g}$ & $\mu \mathrm{g} / \mathrm{g}$ & $\mu \mathrm{g} / \mathrm{g}$ & $\mu \mathrm{g} / \mathrm{g}$ & $\mu \mathrm{g} / \mathrm{g}$ & $\mu \mathrm{g} / \mathrm{g}$ & $\mu \mathrm{g} / \mathrm{g}$ \\
\hline MRL & 0.5 & 0.05 & 0.1 & 0.1 & 1 & 1 & 10 & 0.1 & 4 & 1 \\
\hline MDL & - & - & - & - & - & - & - & - & - & - \\
\hline Reprod & $<0.6$ & 0.5 & 0.3 & 0.6 & 30 & $<1$ & - & 0.1 & 10 & 7 \\
\hline Ash & 0.7 & 7.0 & 1.0 & 16 & 690 & 2 & ND & 1.0 & 71 & 77 \\
\hline Bvtn & 1.0 & 7.2 & 2.0 & 9.3 & 610 & 1 & ND & 1.2 & 53 & 77 \\
\hline Bvtn-r & 1.0 & 7.2 & 2.0 & 9.5 & 610 & 1 & ND & 1.1 & 55 & 78 \\
\hline Bronson & 0.8 & 6.9 & 2.0 & 5.2 & 670 & 2 & ND & 0.4 & 64 & 68 \\
\hline Cedar & 0.5 & 6.7 & 0.7 & 4.4 & 680 & 2 & ND & 0.2 & 76 & 76 \\
\hline Chicken & ND & 9.7 & 1.0 & 6.8 & 730 & 2 & ND & 0.2 & 61 & 140 \\
\hline Dairy & ND & 8.7 & 2.0 & 7.4 & 620 & 2 & ND & 0.2 & 80 & 59 \\
\hline FanDen & ND & 7.4 & 0.7 & 4.3 & 630 & 1 & ND & 0.3 & 73 & 69 \\
\hline FanDen-r & ND & 6.9 & 0.7 & 4.3 & 620 & 1 & ND & 0.3 & 63 & 67 \\
\hline Fan-92 & 0.9 & 8.1 & 2.0 & 8.6 & 630 & ND & ND & 0.9 & 76 & 75 \\
\hline Fan-93a & 0.8 & 8.4 & 0.8 & 9.9 & 660 & 1 & ND & 0.8 & 87 & 75 \\
\hline Fan-93b & 0.7 & 8.5 & 0.8 & 12 & 660 & 1 & ND & 0.8 & 91 & 76 \\
\hline Fan-93c & 0.6 & 8.5 & 0.9 & 7.3 & 630 & 1 & ND & 0.7 & 83 & 68 \\
\hline UpFan & ND & 8.4 & 1.0 & 3.5 & 670 & 2 & ND & 0.3 & 64 & 73 \\
\hline Gales & 0.6 & 19 & 1.0 & 2.0 & 280 & ND & ND & 0.2 & 64 & 74 \\
\hline McKay & ND & 10 & 3.0 & 10 & 660 & 2 & ND & 0.3 & 67 & 65 \\
\hline LoRock & ND & 7.5 & 0.7 & 7.1 & 690 & 2 & ND & 0.5 & 77 & 75 \\
\hline LoRock-a & 0.5 & 7.5 & 1.0 & 6.6 & 670 & 2 & ND & 0.5 & 71 & 80 \\
\hline LoRock-b & 0.6 & 7.3 & 1.0 & 7.2 & 660 & 2 & ND & 0.6 & 74 & 73 \\
\hline UpRock & 0.6 & 6.8 & 1.0 & 6.8 & 650 & 2 & ND & 1.1 & 65 & 83 \\
\hline UpTual & ND & 14.0 & 1.0 & 3.8 & 460 & ND & ND & 0.2 & 48 & 100 \\
\hline Tual-Els & 0.7 & 9.9 & 2.0 & 8.0 & 550 & 2 & ND & 0.3 & 55 & 85 \\
\hline
\end{tabular}


Appendix B. Bed sediment data—continued

[Abbreviations: mg/g, milligram per gram; $\mu \mathrm{g} / \mathrm{g}$, microgram per gram; ng/g, nanogram per gram; ND, not detected; I, interference; E, estimated value; —, no value]

\begin{tabular}{|c|c|c|c|c|c|c|c|c|c|}
\hline $\begin{array}{c}\text { Site } \\
\text { abbrev }\end{array}$ & Cobalt & Copper & Europium & Gallium & Gold & Holmium & Lanthanum & Lead & Lithium \\
\hline P-Code & 34845 & 34850 & 34855 & 34860 & 34870 & 34875 & 34885 & 34890 & 34895 \\
\hline Units & $\mu \mathrm{g} / \mathrm{g}$ & $\mu \mathrm{g} / \mathrm{g}$ & $\mu \mathrm{g} / \mathrm{g}$ & $\mu \mathrm{g} / \mathrm{g}$ & $\mu \mathrm{g} / \mathrm{g}$ & $\mu \mathrm{g} / \mathrm{g}$ & $\mu \mathrm{g} / \mathrm{g}$ & $\mu \mathrm{g} / \mathrm{g}$ & $\mu \mathrm{g} / \mathrm{g}$ \\
\hline MRL & 1 & 1 & 2 & 4 & 8 & 4 & 2 & 4 & 2 \\
\hline MDL & - & - & - & - & - & - & - & - & - \\
\hline Reprod & 1 & 1 & - & 2 & - & - & 4 & 5 & 10 \\
\hline Ash & 22 & 30 & ND & 18 & ND & ND & 43 & 63 & 20 \\
\hline Bvtn & 26 & 48 & ND & 18 & ND & ND & 28 & 130 & 20 \\
\hline Bvtn-r & 26 & 47 & ND & 18 & ND & ND & 30 & 130 & 20 \\
\hline Bronson & 21 & 33 & ND & 18 & ND & ND & 38 & 32 & 20 \\
\hline Cedar & 20 & 24 & ND & 17 & ND & ND & 44 & 28 & 20 \\
\hline Chicken & 23 & 22 & ND & 22 & ND & ND & 39 & 18 & 30 \\
\hline Dairy & 21 & 20 & ND & 21 & ND & ND & 48 & 18 & 30 \\
\hline FanDen & 21 & 25 & ND & 16 & ND & ND & 38 & 57 & 20 \\
\hline FanDen-r & 21 & 25 & ND & 14 & ND & ND & 34 & 52 & 20 \\
\hline Fan-92 & 24 & 44 & ND & 18 & ND & ND & 41 & 58 & 20 \\
\hline Fan-93a & 25 & 41 & ND & 18 & ND & ND & 45 & 52 & 20 \\
\hline Fan-93b & 24 & 34 & ND & 18 & ND & ND & 47 & 52 & 20 \\
\hline Fan-93c & 30 & 37 & ND & 18 & ND & ND & 41 & 46 & 20 \\
\hline UpFan & 21 & 28 & ND & 18 & ND & ND & 38 & 43 & 20 \\
\hline Gales & 40 & 55 & ND & 22 & ND & ND & 40 & $\mathrm{ND}$ & 20 \\
\hline McKay & 24 & 20 & ND & 21 & ND & ND & 42 & 19 & 20 \\
\hline LoRock & 17 & 27 & ND & 18 & ND & ND & 46 & 24 & 30 \\
\hline LoRock-a & 18 & 28 & ND & 18 & ND & ND & 43 & 25 & 30 \\
\hline LoRock-b & 17 & 28 & ND & 18 & ND & ND & 43 & 28 & 20 \\
\hline UpRock & 18 & 40 & ND & 18 & ND & ND & 39 & 35 & 20 \\
\hline UpTual & 29 & 67 & ND & 20 & ND & ND & 32 & 7 & 30 \\
\hline Tual-Els & 24 & 46 & ND & 20 & ND & ND & 34 & 14 & 30 \\
\hline
\end{tabular}


Appendix B. Bed sediment data—continued

[Abbreviations: mg/g, milligram per gram; $\mu \mathrm{g} / \mathrm{g}$, microgram per gram; ng/g, nanogram per gram; ND, not detected; I, interference; E, estimated value; —, no value]

\begin{tabular}{|c|c|c|c|c|c|c|c|c|c|}
\hline $\begin{array}{c}\text { Site } \\
\text { abbrev }\end{array}$ & Manganese & Mercury & Molybdenum & Neodymium & Nickel & Niobium & Scandium & Selenium & Silver \\
\hline P-Code & 34905 & 34910 & 34915 & 34920 & 34925 & 34930 & 34945 & 34950 & 34955 \\
\hline Units & $\mu \mathrm{g} / \mathrm{g}$ & $\mu \mathrm{g} / \mathrm{g}$ & $\mu \mathrm{g} / \mathrm{g}$ & $\mu \mathrm{g} / \mathrm{g}$ & $\mu \mathrm{g} / \mathrm{g}$ & $\mu \mathrm{g} / \mathrm{g}$ & $\mu \mathrm{g} / \mathrm{g}$ & $\mu \mathrm{g} / \mathrm{g}$ & $\mu \mathrm{g} / \mathrm{g}$ \\
\hline MRL & 4 & 0.02 & 2 & 4 & 2 & 4 & 2 & 0.1 & 0.1 \\
\hline MDL & - & - & - & - & - & - & - & - & - \\
\hline Reprod & 250 & 0.01 & - & 5 & 1 & 3 & $<1$ & $<0.1$ & 0.1 \\
\hline Ash & 1300 & 0.09 & ND & 38 & 27 & 12 & 17 & 0.2 & 0.2 \\
\hline Bvtn & 1900 & 0.22 & ND & 25 & 29 & 18 & 17 & 0.2 & 0.5 \\
\hline Bvtn-r & 1900 & 0.21 & ND & 25 & 29 & 19 & 17 & 0.2 & 0.5 \\
\hline Bronson & 1400 & 0.05 & ND & 34 & 22 & 12 & 14 & 0.2 & 0.2 \\
\hline Cedar & 1000 & 0.11 & ND & 36 & 25 & 13 & 15 & 0.2 & 0.2 \\
\hline Chicken & 2200 & 0.30 & ND & 35 & 23 & 12 & 19 & 0.3 & 0.2 \\
\hline Dairy & 1200 & 0.03 & ND & 43 & 18 & 15 & 19 & 0.3 & ND \\
\hline FanDen & 1000 & 0.07 & ND & 32 & 22 & 13 & 14 & 0.1 & 0.2 \\
\hline FanDen-r & 1000 & 0.07 & ND & 27 & 21 & 10 & 14 & 0.1 & 0.2 \\
\hline Fan-92 & 1700 & 0.11 & ND & 35 & 27 & 11 & 18 & 0.2 & 1.3 \\
\hline Fan-93a & 2700 & 0.06 & ND & 39 & 28 & 18 & 19 & 0.2 & 1.1 \\
\hline Fan-93b & 2300 & 0.06 & ND & 41 & 26 & 18 & 18 & 0.2 & 0.9 \\
\hline Fan-93c & 1400 & 0.04 & ND & 39 & 25 & 18 & 21 & 0.2 & 0.7 \\
\hline UpFan & 880 & 0.07 & ND & 34 & 22 & 13 & 15 & ND & 0.2 \\
\hline Gales & 1300 & 0.07 & ND & 42 & 50 & 35 & 23 & 0.9 & 0.2 \\
\hline McKay & 1500 & 0.24 & ND & 38 & 21 & 14 & 20 & 0.3 & ND \\
\hline LoRock & 1000 & 0.06 & ND & 39 & 25 & 14 & 16 & 0.2 & 0.3 \\
\hline LoRock-a & 850 & 0.06 & ND & 37 & 24 & 12 & 16 & 0.2 & 0.3 \\
\hline LoRock-b & 1100 & 0.07 & ND & 38 & 24 & 13 & 16 & 0.2 & 0.4 \\
\hline UpRock & 1500 & 0.10 & ND & 35 & 24 & 12 & 14 & 0.2 & 0.5 \\
\hline UpTual & 1400 & ND & ND & 32 & 40 & 21 & 25 & 0.6 & ND \\
\hline Tual-Els & 1200 & 0.05 & ND & 34 & 31 & 16 & 21 & 0.5 & 0.3 \\
\hline
\end{tabular}


Appendix B. Bed sediment data—continued

[Abbreviations: mg/g, milligram per gram; $\mu \mathrm{g} / \mathrm{g}$, microgram per gram; ng/g, nanogram per gram; ND, not detected; I, interference; E, estimated value; —, no value]

\begin{tabular}{|c|c|c|c|c|c|c|c|c|c|}
\hline $\begin{array}{c}\text { Site } \\
\text { abbrev }\end{array}$ & Strontium & Tantalum & Thorium & Tin & Uranium & Vanadium & Yttrium & Ytterbium & Zinc \\
\hline P-Code & 34965 & 34975 & 34980 & 34985 & 35000 & 35005 & 35010 & 35015 & 35020 \\
\hline Units & $\mu \mathrm{g} / \mathrm{g}$ & $\mu \mathrm{g} / \mathrm{g}$ & $\mu \mathrm{g} / \mathrm{g}$ & $\mu \mathrm{g} / \mathrm{g}$ & $\mu \mathrm{g} / \mathrm{g}$ & $\mu \mathrm{g} / \mathrm{g}$ & $\mu \mathrm{g} / \mathrm{g}$ & $\mu \mathrm{g} / \mathrm{g}$ & $\mu \mathrm{g} / \mathrm{g}$ \\
\hline MRL & 2 & 40 & 1 & 5 & 0.05 & 2 & 2 & 1 & 2 \\
\hline MDL & - & - & - & - & - & - & - & - & - \\
\hline Reprod & 10 & - & 3 & - & 0.35 & 10 & 2 & 1 & 10 \\
\hline Ash & 250 & ND & 13 & ND & 2.76 & 140 & 30 & 3 & 210 \\
\hline Bvtn & 250 & ND & 12 & ND & 2.93 & 150 & 30 & 2 & 400 \\
\hline Bvtn-r & 250 & ND & 9.5 & ND & 2.83 & 140 & 30 & 2 & 400 \\
\hline Bronson & 250 & ND & 12 & ND & 3.56 & 130 & 23 & 2 & 220 \\
\hline Cedar & 260 & ND & 11 & ND & 3.53 & 120 & 23 & 2 & 140 \\
\hline Chicken & 200 & ND & 12 & ND & 3.46 & 170 & 27 & 2 & 130 \\
\hline Dairy & 200 & ND & 16 & ND & 4.60 & 160 & 26 & 3 & 120 \\
\hline FanDen & 280 & ND & 14 & ND & 4.09 & 130 & 28 & 2 & 160 \\
\hline FanDen-r & 280 & ND & 15 & ND & 4.20 & 130 & 27 & 2 & 160 \\
\hline Fan-92 & 260 & ND & 12 & ND & 2.94 & 170 & 25 & 2 & 340 \\
\hline Fan-93a & 260 & ND & 12 & 6 & 3.17 & 170 & 25 & 2 & 300 \\
\hline Fan-93b & 270 & ND & 11 & ND & 3.37 & 170 & 24 & 2 & 280 \\
\hline Fan-93c & 280 & ND & 10 & ND & 3.03 & 190 & 27 & 3 & 260 \\
\hline UpFan & 270 & ND & 16 & $\mathrm{ND}(10)^{\mathrm{c}}$ & 3.83 & 130 & 21 & 2 & 160 \\
\hline Gales & 300 & ND & 5.8 & ND & 1.54 & 280 & 32 & 3 & 120 \\
\hline McKay & 210 & ND & 14 & ND & 3.81 & 180 & 28 & 3 & 120 \\
\hline LoRock & 230 & ND & 13 & ND & 3.41 & 130 & 27 & 3 & 140 \\
\hline LoRock-a & 240 & ND & 12 & ND & 3.63 & 120 & 26 & 2 & 140 \\
\hline LoRock-b & 240 & ND & 15 & ND & 3.28 & 120 & 25 & 2 & 150 \\
\hline UpRock & 250 & ND & 13 & ND & 3.53 & 110 & 23 & 2 & 190 \\
\hline UpTual & 220 & ND & 8.2 & ND & 2.66 & 240 & 27 & 3 & 120 \\
\hline Tual-Els & 200 & ND & 10 & ND & 3.02 & 170 & 27 & 2 & 140 \\
\hline
\end{tabular}


Appendix B. Bed sediment data—continued

[Abbreviations: mg/g, milligram per gram; $\mu \mathrm{g} / \mathrm{g}$, microgram per gram; ng/g, nanogram per gram; ND, not detected; I, interference; E, estimated value; —, no value]

\begin{tabular}{|c|c|c|c|c|c|c|c|c|c|}
\hline $\begin{array}{c}\text { Site } \\
\text { abbrev }\end{array}$ & Aldrin & cis-Chlordane & $\begin{array}{c}\text { trans- } \\
\text { Chlordane }\end{array}$ & Chlorneb & Dacthal & $0, p^{\prime}-\mathrm{DDE}$ & $p, p^{\prime}$-DDE & Dieldrin & Endosulfan I \\
\hline P-Code & 49319 & 49320 & 49321 & 49322 & 49324 & 49327 & 49328 & 49331 & 49332 \\
\hline Units & $\mathrm{ng} / \mathrm{g}$ & $\mathrm{ng} / \mathrm{g}$ & $\mathrm{ng} / \mathrm{g}$ & $\mathrm{ng} / \mathrm{g}$ & $\mathrm{ng} / \mathrm{g}$ & $\mathrm{ng} / \mathrm{g}$ & $\mathrm{ng} / \mathrm{g}$ & $\mathrm{ng} / \mathrm{g}$ & $\mathrm{ng} / \mathrm{g}$ \\
\hline MRL & 1.0 & 1.0 & 1.0 & 5.0 & 5.0 & 1.0 & 1.0 & 1.0 & 1.0 \\
\hline MDL & - & - & - & - & - & - & - & - & - \\
\hline Reprod & - & 1.4 & 0.7 & - & - & 0.4 & 0.3 & 0.9 & - \\
\hline Ash & ND & ND & ND & ND & ND & ND & 1.0 & ND & ND \\
\hline Bvtn & $\mathrm{ND}(2.0)^{\mathrm{c}}$ & 9.8 & 8.6 & ND & ND & 3.9 & 4.7 & 6.5 & ND \\
\hline Bvtn-r & $\mathrm{ND}(2.0)^{\mathrm{c}}$ & 8.4 & 7.9 & ND & ND & 3.5 & 4.5 & 7.4 & ND \\
\hline Bronson & ND & 1.7 & 1.2 & ND & ND & ND & ND & ND & ND \\
\hline Cedar & ND & 1.0 & ND & ND & ND & ND & 1.0 & ND & ND \\
\hline Chicken & ND & ND & ND & ND & ND & ND & 6.3 & ND & ND \\
\hline Dairy & ND & ND & ND & ND & ND & ND & 1.0 & ND & ND \\
\hline FanDen & ND & 5.8 & 5.2 & ND & ND & 1.6 & 2.1 & 3.8 & ND \\
\hline FanDen-r & $\mathrm{ND}(1.2)^{\mathrm{c}}$ & 6.3 & 5.1 & ND & ND & 1.8 & 2.1 & 3.6 & ND \\
\hline Fan-92 & ND & ND & ND & ND & ND & ND & ND & ND & ND \\
\hline Fan-93a & ND & ND & ND & ND & ND & ND & ND & ND & ND \\
\hline Fan-93b & ND & ND & ND & ND & ND & ND & ND & ND & ND \\
\hline Fan-93c & ND & ND & ND & ND & ND & ND & ND & ND & ND \\
\hline UpFan & ND & 4.1 & 3.8 & ND & ND & ND & 10 & 3.7 & ND \\
\hline Gales & ND & ND & ND & ND & ND & ND & ND & ND & ND \\
\hline McKay & ND & ND & ND & ND & ND & ND & 1.1 & ND & ND \\
\hline LoRock & ND & ND & ND & ND & ND & ND & 1.3 & ND & ND \\
\hline LoRock-a & ND & ND & ND & ND & ND & ND & ND & ND & ND \\
\hline LoRock-b & ND & ND & ND & ND & ND & ND & 1.6 & ND & ND \\
\hline UpRock & ND & 1.8 & 1.5 & ND & ND & ND & 1.9 & ND & ND \\
\hline UpTual & ND & ND & ND & ND & ND & ND & ND & ND & ND \\
\hline Tual-Els & ND & ND & ND & ND & ND & ND & 2.0 & ND & ND \\
\hline
\end{tabular}


Appendix B. Bed sediment data—continued

[Abbreviations: mg/g, milligram per gram; $\mu \mathrm{g} / \mathrm{g}$, microgram per gram; ng/g, nanogram per gram; ND, not detected; I, interference; E, estimated value; —, no value]

\begin{tabular}{|c|c|c|c|c|c|c|c|c|c|}
\hline $\begin{array}{c}\text { Site } \\
\text { abbrev }\end{array}$ & Endrin & $\alpha-\mathrm{HCH}$ & $\beta-\mathrm{HCH}$ & $\gamma-\mathrm{HCH}$ & Heptachlor & $\begin{array}{l}\text { Heptachlor } \\
\text { Epoxide }\end{array}$ & Isodrin & $\begin{array}{c}\text { o,p'- } \\
\text { Methoxychlor }\end{array}$ & $\begin{array}{c}p, p^{\prime}- \\
\text { ethoxychlor }\end{array}$ \\
\hline P-Code & 49335 & 49338 & 49339 & 49345 & 49341 & 49342 & 49344 & 49347 & 49346 \\
\hline Units & $\mathrm{ng} / \mathrm{g}$ & $\mathrm{ng} / \mathrm{g}$ & $\mathrm{ng} / \mathrm{g}$ & $\mathrm{ng} / \mathrm{g}$ & $\mathrm{ng} / \mathrm{g}$ & $\mathrm{ng} / \mathrm{g}$ & $\mathrm{ng} / \mathrm{g}$ & $\mathrm{ng} / \mathrm{g}$ & $\mathrm{ng} / \mathrm{g}$ \\
\hline MRL & 2.0 & 1.0 & 1.0 & 1.0 & 1.0 & 1.0 & 1.0 & 5.0 & 5.0 \\
\hline MDL & - & - & - & - & - & - & - & - & - \\
\hline Reprod & - & - & - & - & - & 0.1 & - & - & - \\
\hline Ash & ND & ND & ND & ND & ND & ND & ND & ND & ND \\
\hline Bvtn & ND & ND & ND & ND & ND & 1.4 & ND & ND & ND \\
\hline Bvtn-r & ND & ND & ND & ND & ND & 1.3 & ND & ND & ND \\
\hline Bronson & ND & ND & ND & ND & ND & ND & ND & - & - \\
\hline Cedar & ND & ND & ND & ND & ND & ND & ND & - & - \\
\hline Chicken & ND & ND & ND & ND & ND & ND & ND & - & - \\
\hline Dairy & ND & ND & ND & ND & ND & ND & ND & - & - \\
\hline FanDen & ND & ND & ND & ND & ND & ND & ND & ND & ND \\
\hline FanDen-r & ND & ND & ND & ND & ND & ND & ND & ND & ND \\
\hline Fan-92 & ND & ND & ND & ND & ND & ND & ND & ND & ND \\
\hline Fan-93a & ND & ND & ND & ND & ND & ND & ND & ND & ND \\
\hline Fan-93b & ND & ND & ND & ND & ND & ND & ND & ND & ND \\
\hline Fan-93c & ND & ND & ND & ND & ND & ND & ND & ND & ND \\
\hline UpFan & ND & ND & ND & ND & ND & ND & ND & ND & ND \\
\hline Gales & ND & ND & ND & ND & ND & ND & ND & ND & ND \\
\hline McKay & ND & ND & ND & ND & ND & ND & ND & - & - \\
\hline LoRock & ND & ND & ND & ND & ND & ND & ND & - & - \\
\hline LoRock-a & ND & ND & ND & ND & ND & ND & ND & - & - \\
\hline LoRock-b & ND & ND & ND & ND & ND & ND & ND & - & - \\
\hline UpRock & ND & ND & ND & ND & ND & ND & ND & - & - \\
\hline UpTual & ND & ND & ND & ND & ND & ND & ND & ND & ND \\
\hline Tual-Els & ND & ND & ND & ND & ND & ND & ND & - & - \\
\hline
\end{tabular}


Appendix B. Bed sediment data—continued

[Abbreviations: mg/g, milligram per gram; $\mu \mathrm{g} / \mathrm{g}$, microgram per gram; ng/g, nanogram per gram; ND, not detected; I, interference; E, estimated value; —, no value]

\begin{tabular}{|c|c|c|c|c|c|c|c|c|c|}
\hline $\begin{array}{c}\text { Site } \\
\text { abbrev }\end{array}$ & Mirex & cis-Nonachlor & $\begin{array}{c}\text { trans- } \\
\text { Nonachlor }\end{array}$ & Oxychlordane & $\begin{array}{c}\text { cis- } \\
\text { Permethrin }\end{array}$ & $\begin{array}{c}\text { trans- } \\
\text { Permethrin }\end{array}$ & Toxaphene & $\begin{array}{l}\text { Acenaph- } \\
\text { thene }\end{array}$ & $\begin{array}{c}\text { Acenaph- } \\
\text { thylene }\end{array}$ \\
\hline P-Code & 49348 & 49316 & 49317 & 49318 & 49349 & 49350 & 49351 & 49429 & 49428 \\
\hline Units & $\mathrm{ng} / \mathrm{g}$ & $\mathrm{ng} / \mathrm{g}$ & $\mathrm{ng} / \mathrm{g}$ & $\mathrm{ng} / \mathrm{g}$ & $\mathrm{ng} / \mathrm{g}$ & $\mathrm{ng} / \mathrm{g}$ & $\mathrm{ng} / \mathrm{g}$ & $\mathrm{ng} / \mathrm{g}$ & $\mathrm{ng} / \mathrm{g}$ \\
\hline MRL & 1.0 & 1.0 & 1.0 & 1.0 & 5.0 & 5.0 & 200 & - & - \\
\hline MDL & - & - & - & - & - & - & - & 31 & 29 \\
\hline Reprod & - & 0.1 & 0.4 & - & - & - & - & - & 2 \\
\hline Ash & $\mathrm{ND}(2.0)^{\mathrm{c}}$ & ND & ND & ND & ND & ND & ND & $17^{\mathrm{d}}$ & 30 \\
\hline Bvtn & ND & 2.4 & 7.8 & ND & ND & I & ND & I & I \\
\hline Bvtn-r & ND & 2.3 & 7.4 & ND & ND & I & ND & I & I \\
\hline Bronson & ND & 1.1 & 1.6 & ND & ND & ND & ND & ND & ND \\
\hline Cedar & ND & ND & ND & ND & ND & ND & ND & ND & ND \\
\hline Chicken & ND & ND & ND & ND & ND & ND & ND & ND & ND \\
\hline Dairy & ND & ND & ND & ND & ND & ND & ND & ND & ND \\
\hline FanDen & ND & 1.5 & 4.9 & ND & ND & I & ND & ND & E19 ${ }^{d}$ \\
\hline FanDen-r & ND & 1.6 & 4.9 & ND & ND & I & ND & ND & $\mathrm{E} 21^{\mathrm{d}}$ \\
\hline Fan-92 & ND & ND & ND & ND & ND & ND & ND & ND & ND \\
\hline Fan-93a & ND & ND & ND & ND & ND & ND & ND & ND & ND \\
\hline Fan-93b & ND & ND & ND & ND & ND & ND & ND & ND & ND \\
\hline Fan-93c & ND & ND & ND & ND & ND & ND & ND & ND & ND \\
\hline UpFan & ND & 2.2 & 3.9 & ND & ND & ND & ND & $15^{\mathrm{d}}$ & $21^{\mathrm{d}}$ \\
\hline Gales & ND & ND & ND & ND & ND & ND & ND & ND & ND \\
\hline McKay & ND & ND & ND & ND & ND & ND & ND & $16^{\mathrm{d}}$ & 38 \\
\hline LoRock & ND & $\mathrm{ND}(2.0)^{\mathrm{c}}$ & ND & ND & ND & ND & ND & ND & ND \\
\hline LoRock-a & ND & ND & ND & ND & ND & ND & ND & ND & ND \\
\hline LoRock-b & ND & ND & ND & ND & ND & ND & ND & ND & ND \\
\hline UpRock & ND & $\mathrm{ND}(2.0)^{\mathrm{c}}$ & 1.2 & ND & ND & ND & ND & $17^{\mathrm{d}}$ & $27^{\mathrm{d}}$ \\
\hline UpTual & $\mathrm{ND}(2.0)^{\mathrm{c}}$ & ND & ND & ND & ND & ND & ND & ND & ND \\
\hline Tual-Els & ND & ND & ND & ND & ND & ND & ND & ND & ND \\
\hline
\end{tabular}


Appendix B. Bed sediment data—continued

[Abbreviations: mg/g, milligram per gram; $\mu \mathrm{g} / \mathrm{g}$, microgram per gram; ng/g, nanogram per gram; ND, not detected; I, interference; E, estimated value; —, no value]

\begin{tabular}{|c|c|c|c|c|c|c|c|c|c|}
\hline $\begin{array}{c}\text { Site } \\
\text { abbrev }\end{array}$ & Anthracene & $\begin{array}{c}\text { Benz[a]- } \\
\text { anthracene }\end{array}$ & $\begin{array}{c}\text { Benzo[a]- } \\
\text { pyrene }\end{array}$ & $\begin{array}{l}\text { Benzo }[b]- \\
\text { fluoranthene }\end{array}$ & $\begin{array}{c}\text { Benzo[ghi]- } \\
\text { perylene }\end{array}$ & $\begin{array}{c}\text { Benzo }[k]- \\
\text { fluoranthene }\end{array}$ & Chrysene & $\begin{array}{l}\text { Dibenz }[a, h]- \\
\text { anthracene }\end{array}$ & Fluoranthene \\
\hline P-Code & 49434 & 49436 & 49389 & 49458 & 49408 & 49397 & 49450 & 49461 & 49466 \\
\hline Units & $\mathrm{ng} / \mathrm{g}$ & $\mathrm{ng} / \mathrm{g}$ & $\mathrm{ng} / \mathrm{g}$ & $\mathrm{ng} / \mathrm{g}$ & $\mathrm{ng} / \mathrm{g}$ & $\mathrm{ng} / \mathrm{g}$ & $\mathrm{ng} / \mathrm{g}$ & $\mathrm{ng} / \mathrm{g}$ & $\mathrm{ng} / \mathrm{g}$ \\
\hline MRL & - & - & - & - & - & - & - & - & - \\
\hline MDL & 28 & 23 & 19 & 20 & 64 & 33 & 24 & 25 & 29 \\
\hline Reprod & 11 & 40 & 80 & 60 & 30 & 50 & 80 & - & 70 \\
\hline Ash & 130 & 300 & 560 & 250 & 82 & 300 & 340 & 35 & 260 \\
\hline Bvtn & I & E480 & E390 & E680 & 470 & E280 & 670 & ND & 890 \\
\hline Bvtn-r & I & E440 & E310 & E620 & 440 & E330 & 590 & ND & 820 \\
\hline Bronson & ND & 110 & 53 & 88 & ND & 88 & 110 & ND & 70 \\
\hline Cedar & 31 & 45 & ND & 52 & ND & 71 & 57 & ND & 61 \\
\hline Chicken & 32 & 44 & ND & 55 & ND & 51 & 49 & ND & 54 \\
\hline Dairy & 35 & 54 & ND & 48 & ND & 58 & 63 & ND & 60 \\
\hline FanDen & E33 & 98 & 120 & E91 & 84 & 110 & E260 & ND & 340 \\
\hline FanDen-r & E44 & 100 & 130 & E 100 & 88 & 110 & $\mathrm{E} 270$ & ND & 360 \\
\hline Fan-92 & $24^{d}$ & 110 & 120 & 89 & 110 & 150 & 180 & $24^{\mathrm{d}}$ & 260 \\
\hline Fan-93a & $13^{d}$ & 23 & 35 & 66 & $23^{d}$ & $28^{\mathrm{d}}$ & 61 & ND & 90 \\
\hline Fan-93b & 37 & 94 & 130 & 140 & $63^{d}$ & 140 & 190 & ND & 290 \\
\hline Fan-93c & $16^{\mathrm{d}}$ & $7^{d}$ & $7^{d}$ & $10^{\mathrm{d}}$ & ND & $9^{d}$ & ND & ND & $19^{\mathrm{d}}$ \\
\hline UpFan & 44 & 80 & 200 & 280 & $50^{d}$ & 220 & 170 & ND & 220 \\
\hline Gales & ND & ND & ND & ND & ND & ND & ND & ND & ND \\
\hline McKay & 68 & 120 & 68 & 130 & ND & 120 & 170 & ND & 380 \\
\hline LoRock & 31 & 43 & ND & 60 & ND & 54 & 50 & ND & 50 \\
\hline LoRock-a & 32 & 45 & ND & 60 & ND & 58 & 50 & ND & 53 \\
\hline LoRock-b & 34 & 52 & ND & 67 & ND & 61 & 60 & ND & 69 \\
\hline UpRock & 50 & 67 & 55 & 73 & ND & 100 & 94 & ND & 130 \\
\hline UpTual & ND & ND & ND & ND & ND & ND & ND & ND & ND \\
\hline Tual-Els & ND & 44 & ND & 56 & ND & 53 & 45 & ND & 50 \\
\hline
\end{tabular}


Appendix B. Bed sediment data—continued

[Abbreviations: mg/g, milligram per gram; $\mu \mathrm{g} / \mathrm{g}$, microgram per gram; ng/g, nanogram per gram; ND, not detected; I, interference; E, estimated value; —, no value]

\begin{tabular}{|c|c|c|c|c|c|c|c|c|c|}
\hline $\begin{array}{c}\text { Site } \\
\text { abbrev }\end{array}$ & 9H-Fluorene & $\begin{array}{c}\text { Indeno[1,2,3- } \\
\text { cd]pyrene }\end{array}$ & Naphthalene & Phenanthrene & Pyrene & $\begin{array}{l}\text { 1,2-Dimethyl- } \\
\text { naphthalene }\end{array}$ & $\begin{array}{l}\text { 1,6-Dimethyl- } \\
\text { naphthalene }\end{array}$ & $\begin{array}{l}\text { 2,6-Dimethyl- } \\
\text { naphthalene }\end{array}$ & $\begin{array}{c}\text { 2-Ethyl- } \\
\text { naphthalene }\end{array}$ \\
\hline P-Code & 49399 & 49390 & 49402 & 49409 & 49387 & 49403 & 49404 & 49406 & 49948 \\
\hline Units & $\mathrm{ng} / \mathrm{g}$ & $\mathrm{ng} / \mathrm{g}$ & $\mathrm{ng} / \mathrm{g}$ & $\mathrm{ng} / \mathrm{g}$ & $\mathrm{ng} / \mathrm{g}$ & $\mathrm{ng} / \mathrm{g}$ & $\mathrm{ng} / \mathrm{g}$ & $\mathrm{ng} / \mathrm{g}$ & $\mathrm{ng} / \mathrm{g}$ \\
\hline MRL & - & - & - & - & - & - & - & - & - \\
\hline MDL & 32 & 25 & 26 & 30 & 27 & 27 & 28 & 26 & 28 \\
\hline Reprod & - & 10 & - & 50 & 100 & - & - & 9 & - \\
\hline Ash & $24^{\mathrm{d}}$ & 130 & $10^{\mathrm{d}}$ & 170 & 260 & ND & $11^{\mathrm{d}}$ & 71 & ND \\
\hline Bvtn & I & E470 & I & E250 & 1100 & I & I & I & I \\
\hline Bvtn-r & I & I & I & E200 & 1000 & I & I & I & I \\
\hline Bronson & ND & 79 & $12^{\mathrm{d}}$ & ND & 95 & ND & ND & 120 & ND \\
\hline Cedar & ND & ND & ND & $28^{\mathrm{d}}$ & 75 & ND & ND & 30 & ND \\
\hline Chicken & ND & ND & ND & $26^{\mathrm{d}}$ & 63 & ND & ND & 36 & ND \\
\hline Dairy & ND & ND & ND & 31 & 60 & ND & ND & $23^{\mathrm{d}}$ & ND \\
\hline FanDen & ND & 69 & ND & 150 & 430 & ND & ND & E30 & ND \\
\hline FanDen-r & ND & 75 & ND & 170 & 460 & ND & ND & E28 & ND \\
\hline Fan-92 & $9^{d}$ & 85 & ND & 140 & 240 & ND & ND & ND & ND \\
\hline Fan-93a & ND & $22^{d}$ & ND & 41 & 89 & ND & ND & 29 & ND \\
\hline Fan-93b & ND & 59 & ND & 150 & 240 & ND & ND & 38 & ND \\
\hline Fan-93c & ND & $12^{\mathrm{d}}$ & ND & $17^{\mathrm{d}}$ & $22^{d}$ & ND & ND & 86 & ND \\
\hline UpFan & $20^{\mathrm{d}}$ & 80 & ND & 140 & 230 & ND & ND & $20^{\mathrm{d}}$ & ND \\
\hline Gales & ND & ND & ND & ND & ND & ND & ND & ND & ND \\
\hline McKay & $29^{d}$ & 83 & $25^{d}$ & 150 & 250 & ND & ND & 27 & ND \\
\hline LoRock & ND & 60 & ND & $20^{d}$ & 58 & ND & ND & 29 & ND \\
\hline LoRock-a & ND & ND & ND & $23^{d}$ & 60 & ND & ND & 28 & ND \\
\hline LoRock-b & ND & ND & ND & 34 & 72 & ND & ND & 37 & ND \\
\hline UpRock & $28^{\mathrm{d}}$ & 62 & ND & 64 & 130 & $7^{\mathrm{d}}$ & ND & 70 & ND \\
\hline UpTual & ND & ND & ND & ND & ND & ND & ND & $17^{\mathrm{d}}$ & ND \\
\hline Tual-Els & ND & ND & ND & ND & 53 & ND & ND & 89 & ND \\
\hline
\end{tabular}


Appendix B. Bed sediment data—continued

[Abbreviations: mg/g, milligram per gram; $\mu \mathrm{g} / \mathrm{g}$, microgram per gram; ng/g, nanogram per gram; ND, not detected; I, interference; E, estimated value; —, no value]

\begin{tabular}{|c|c|c|c|c|c|c|c|c|c|}
\hline $\begin{array}{c}\text { Site } \\
\text { abbrev }\end{array}$ & $\begin{array}{l}\text { 1-Methyl-9H- } \\
\text { fluorene }\end{array}$ & $\begin{array}{c}\text { 1-Methyl- } \\
\text { phenanthrene }\end{array}$ & $\begin{array}{l}\text { 1-Methyl- } \\
\text { pyrene }\end{array}$ & $\begin{array}{l}\text { 2-Methyl- } \\
\text { anthracene }\end{array}$ & $\begin{array}{c}\text { 4,5- } \\
\text { Methylene- } \\
\text { phenanthrene }\end{array}$ & $\begin{array}{c}\text { 2,3,6- } \\
\text { Trimethyl- } \\
\text { naphthylene }\end{array}$ & Acridine & $\begin{array}{l}\text { Benzo[c]- } \\
\text { cinnoline }\end{array}$ & $\begin{array}{c}\text { 2,2'- } \\
\text { Biquinoline }\end{array}$ \\
\hline P-Code & 49398 & 49410 & 49388 & 49435 & 49411 & 49405 & 49430 & 49468 & 49391 \\
\hline Units & $\mathrm{ng} / \mathrm{g}$ & $\mathrm{ng} / \mathrm{g}$ & $\mathrm{ng} / \mathrm{g}$ & $\mathrm{ng} / \mathrm{g}$ & $\mathrm{ng} / \mathrm{g}$ & $\mathrm{ng} / \mathrm{g}$ & $\mathrm{ng} / \mathrm{g}$ & $\mathrm{ng} / \mathrm{g}$ & $\mathrm{ng} / \mathrm{g}$ \\
\hline MRL & - & - & - & - & - & - & - & - & - \\
\hline MDL & 32 & 30 & 25 & 25 & 29 & 32 & 24 & 24 & 50 \\
\hline Reprod & - & - & - & - & 3 & - & - & - & - \\
\hline Ash & ND & 53 & 40 & 89 & 42 & ND & ND & ND & ND \\
\hline Bvtn & I & I & I & I & I & I & I & I & I \\
\hline Bvtn-r & I & I & I & I & I & I & I & I & I \\
\hline Bronson & ND & ND & 70 & ND & ND & ND & ND & ND & ND \\
\hline Cedar & ND & ND & ND & ND & 34 & ND & ND & ND & ND \\
\hline Chicken & ND & ND & 48 & ND & 33 & ND & ND & ND & ND \\
\hline Dairy & ND & ND & ND & ND & 37 & ND & ND & ND & 52 \\
\hline FanDen & ND & $\mathrm{E} 27^{\mathrm{d}}$ & ND & ND & E35 & ND & ND & ND & ND \\
\hline FanDen-r & ND & $\mathrm{E} 22^{\mathrm{d}}$ & E42 & E25 & E32 & ND & ND & ND & ND \\
\hline Fan-92 & ND & $16^{\mathrm{d}}$ & $11^{\mathrm{d}}$ & ND & $21^{\mathrm{d}}$ & ND & $9^{d}$ & ND & ND \\
\hline Fan-93a & ND & $8^{d}$ & ND & ND & ND & ND & ND & ND & ND \\
\hline Fan-93b & ND & ND & ND & ND & $27^{\mathrm{d}}$ & ND & $22^{d}$ & ND & ND \\
\hline Fan-93c & ND & ND & ND & ND & ND & ND & ND & ND & ND \\
\hline UpFan & ND & $15^{\mathrm{d}}$ & $15^{\mathrm{d}}$ & ND & $25^{\mathrm{d}}$ & ND & ND & ND & ND \\
\hline Gales & ND & ND & ND & ND & ND & ND & ND & ND & ND \\
\hline McKay & ND & 50 & 55 & ND & 62 & ND & 37 & ND & 56 \\
\hline LoRock & ND & 34 & ND & ND & 36 & ND & ND & ND & ND \\
\hline LoRock-a & ND & ND & ND & ND & 35 & ND & ND & ND & ND \\
\hline LoRock-b & ND & ND & ND & ND & 37 & ND & ND & ND & ND \\
\hline UpRock & ND & ND & ND & ND & ND & ND & ND & ND & ND \\
\hline UpTual & ND & ND & ND & ND & ND & ND & ND & ND & ND \\
\hline Tual-Els & ND & ND & ND & ND & ND & ND & ND & ND & ND \\
\hline
\end{tabular}


Appendix B. Bed sediment data—continued

[Abbreviations: mg/g, milligram per gram; $\mu \mathrm{g} / \mathrm{g}$, microgram per gram; ng/g, nanogram per gram; ND, not detected; I, interference; E, estimated value; —, no value]

\begin{tabular}{|c|c|c|c|c|c|c|c|c|c|}
\hline $\begin{array}{c}\text { Site } \\
\text { abbrev }\end{array}$ & 9H-Carbazole & Isoquinoline & $\begin{array}{l}\text { Phenan- } \\
\text { thridine }\end{array}$ & Quinoline & $\begin{array}{c}\text { bis(2- } \\
\text { Ethylhexyl)- } \\
\text { phthalate }\end{array}$ & $\begin{array}{c}\text { Butylbenzyl- } \\
\text { phthalate }\end{array}$ & $\begin{array}{l}\text { Diethyl- } \\
\text { phthalate }\end{array}$ & $\begin{array}{l}\text { Dimethyl- } \\
\text { phthalate }\end{array}$ & $\begin{array}{c}\text { Di-n-butyl- } \\
\text { phthalate }\end{array}$ \\
\hline P-Code & 49449 & 49394 & 49393 & 49392 & 49426 & 49427 & 49383 & 49384 & 49381 \\
\hline Units & $\mathrm{ng} / \mathrm{g}$ & $\mathrm{ng} / \mathrm{g}$ & $\mathrm{ng} / \mathrm{g}$ & $\mathrm{ng} / \mathrm{g}$ & $\mathrm{ng} / \mathrm{g}$ & $\mathrm{ng} / \mathrm{g}$ & $\mathrm{ng} / \mathrm{g}$ & $\mathrm{ng} / \mathrm{g}$ & $\mathrm{ng} / \mathrm{g}$ \\
\hline MRL & - & - & - & - & - & - & - & - & - \\
\hline MDL & 28 & 28 & 26 & 30 & 31 & 27 & 31 & 27 & 28 \\
\hline Reprod & - & - & - & - & 100 & 80 & - & - & 10 \\
\hline Ash & $23^{d}$ & ND & ND & ND & 3500 & 1400 & ND & ND & 60 \\
\hline Bvtn & I & I & I & I & E10000 & E1000 & I & I & I \\
\hline Bvtn-r & I & I & I & I & E 10000 & 920 & I & I & I \\
\hline Bronson & ND & ND & 64 & ND & 2300 & 150 & $19^{\mathrm{d}}$ & ND & 99 \\
\hline Cedar & ND & ND & ND & ND & 330 & 67 & $18^{\mathrm{d}}$ & ND & 72 \\
\hline Chicken & ND & ND & ND & ND & 130 & 64 & $18^{\mathrm{d}}$ & ND & 68 \\
\hline Dairy & ND & ND & ND & ND & 100 & 70 & $21^{\mathrm{d}}$ & ND & 77 \\
\hline FanDen & ND & ND & ND & ND & E1000 & 93 & E39 & ND & E46 \\
\hline FanDen-r & $\mathrm{E} 22^{\mathrm{d}}$ & ND & ND & ND & E1100 & 110 & ND & ND & E44 \\
\hline Fan-92 & $17^{\mathrm{d}}$ & ND & ND & ND & 59 & 54 & ND & ND & 88 \\
\hline Fan-93a & ND & ND & ND & ND & 1100 & 760 & $7^{d}$ & ND & 44 \\
\hline Fan-93b & 29 & ND & ND & ND & 810 & $22^{d}$ & $6^{\mathrm{d}}$ & ND & 48 \\
\hline Fan-93c & ND & ND & ND & ND & 43 & $22^{d}$ & ND & ND & 50 \\
\hline UpFan & $12^{\mathrm{d}}$ & ND & ND & ND & 820 & 160 & ND & ND & 30 \\
\hline Gales & ND & ND & ND & ND & 31 & ND & ND & ND & $21^{\mathrm{d}}$ \\
\hline McKay & 50 & 32 & 32 & $14^{\mathrm{d}}$ & 160 & 72 & $22^{d}$ & ND & 77 \\
\hline LoRock & ND & ND & ND & ND & 150 & 74 & $21^{d}$ & ND & 76 \\
\hline LoRock-a & ND & ND & ND & ND & 160 & 72 & $20^{d}$ & ND & 79 \\
\hline LoRock-b & ND & ND & ND & ND & 150 & 75 & $21^{d}$ & ND & 86 \\
\hline UpRock & ND & ND & ND & ND & 330 & 85 & $21^{\mathrm{d}}$ & ND & 90 \\
\hline UpTual & ND & ND & ND & ND & 38 & ND & ND & ND & $26^{\mathrm{d}}$ \\
\hline Tual-Els & ND & ND & ND & ND & 160 & 70 & $19^{d}$ & ND & 76 \\
\hline
\end{tabular}


Appendix B. Bed sediment data—continued

[Abbreviations: mg/g, milligram per gram; $\mu \mathrm{g} / \mathrm{g}$, microgram per gram; ng/g, nanogram per gram; ND, not detected; I, interference; E, estimated value; —, no value]

\begin{tabular}{|c|c|c|c|c|c|c|c|c|c|}
\hline $\begin{array}{c}\text { Site } \\
\text { abbrev }\end{array}$ & $\begin{array}{l}\text { Di-n-octyl- } \\
\text { phthalate }\end{array}$ & $\begin{array}{c}\text { C8- } \\
\text { alkylphenol }\end{array}$ & $\begin{array}{l}\text { 2-Chloro- } \\
\text { phenol }\end{array}$ & $\begin{array}{l}\text { 4-Chloro-3- } \\
\text { methylphenol }\end{array}$ & $p$-Cresol & $\begin{array}{l}\text { 3,5-Dimethyl- } \\
\text { phenol }\end{array}$ & Phenol & $\begin{array}{l}\text { 2-Chloro- } \\
\text { naphthalene }\end{array}$ & $\begin{array}{l}\text { 1,2-Dichloro- } \\
\text { benzene }\end{array}$ \\
\hline P-Code & 49382 & 49424 & 49467 & 49422 & 49451 & 49421 & 49413 & 49407 & 49439 \\
\hline Units & $\mathrm{ng} / \mathrm{g}$ & $\mathrm{ng} / \mathrm{g}$ & $\mathrm{ng} / \mathrm{g}$ & $\mathrm{ng} / \mathrm{g}$ & $\mathrm{ng} / \mathrm{g}$ & $\mathrm{ng} / \mathrm{g}$ & $\mathrm{ng} / \mathrm{g}$ & $\mathrm{ng} / \mathrm{g}$ & $\mathrm{ng} / \mathrm{g}$ \\
\hline MRL & - & - & - & - & - & - & - & - & - \\
\hline MDL & 25 & 30 & 24 & 26 & 32 & 31 & 20 & 29 & 28 \\
\hline Reprod & 37 & - & - & - & 40 & - & - & - & - \\
\hline Ash & 340 & ND & ND & ND & 39 & ND & 58 & ND & ND \\
\hline Bvtn & E820 & I & I & I & 880 & I & I & I & I \\
\hline Bvtn-r & I & I & I & I & 840 & I & I & I & I \\
\hline Bronson & 200 & ND & ND & ND & 160 & ND & 32 & ND & ND \\
\hline Cedar & ND & ND & ND & ND & 40 & ND & $12^{\mathrm{d}}$ & ND & ND \\
\hline Chicken & 100 & ND & ND & ND & ND & ND & $7^{d}$ & ND & ND \\
\hline Dairy & 88 & ND & ND & ND & 85 & ND & 25 & ND & ND \\
\hline FanDen & ND & ND & ND & ND & 140 & ND & ND & ND & ND \\
\hline FanDen-r & E68 & ND & ND & ND & 180 & ND & E24 & ND & ND \\
\hline Fan-92 & ND & ND & ND & ND & ND & ND & ND & ND & ND \\
\hline Fan-93a & 54 & ND & ND & ND & ND & ND & ND & ND & ND \\
\hline Fan-93b & ND & ND & ND & ND & $20^{\mathrm{d}}$ & ND & $13^{\mathrm{d}}$ & ND & ND \\
\hline Fan-93c & ND & ND & ND & ND & 570 & ND & 64 & ND & ND \\
\hline UpFan & 59 & ND & ND & ND & 43 & ND & $16^{\mathrm{d}}$ & ND & ND \\
\hline Gales & ND & ND & ND & ND & ND & ND & ND & ND & ND \\
\hline McKay & 88 & ND & ND & ND & 55 & ND & 22 & ND & ND \\
\hline LoRock & 84 & ND & ND & ND & 33 & ND & $6^{\mathrm{d}}$ & ND & ND \\
\hline LoRock-a & ND & ND & ND & ND & 34 & ND & $7^{d}$ & ND & ND \\
\hline LoRock-b & 87 & ND & ND & ND & 35 & ND & $9^{d}$ & ND & ND \\
\hline UpRock & 88 & ND & ND & ND & 40 & ND & $13^{\mathrm{d}}$ & ND & ND \\
\hline UpTual & ND & ND & ND & ND & ND & ND & $16^{\mathrm{d}}$ & ND & ND \\
\hline Tual-Els & ND & ND & ND & ND & 660 & 43 & $18^{\mathrm{d}}$ & ND & ND \\
\hline
\end{tabular}


Appendix B. Bed sediment data-continued

[Abbreviations: mg/g, milligram per gram; $\mu \mathrm{g} / \mathrm{g}$, microgram per gram; ng/g, nanogram per gram; ND, not detected; I, interference; E, estimated value; —, no value]

\begin{tabular}{|c|c|c|c|c|c|c|c|c|c|}
\hline $\begin{array}{c}\text { Site } \\
\text { abbrev }\end{array}$ & $\begin{array}{l}\text { 1,3-Dichloro- } \\
\text { benzene }\end{array}$ & $\begin{array}{l}\text { 1,4-Dichloro- } \\
\text { benzene }\end{array}$ & $\begin{array}{l}\text { Hexachloro- } \\
\text { benzene }\end{array}$ & $\begin{array}{l}\text { Pentachloro- } \\
\text { anisole }\end{array}$ & $\begin{array}{l}\text { Pentachloro- } \\
\text { nitrobenzene }\end{array}$ & Total PCB & $\begin{array}{c}\text { 1,2,4- } \\
\text { Trichloro- } \\
\text { benzene }\end{array}$ & $\begin{array}{l}\text { Anthra- } \\
\text { quinone }\end{array}$ & Azobenzene \\
\hline P-Code & 49441 & 49442 & 49343 & 49460 & 49446 & 49459 & 49438 & 49437 & 49443 \\
\hline Units & $\mathrm{ng} / \mathrm{g}$ & $\mathrm{ng} / \mathrm{g}$ & $\mathrm{ng} / \mathrm{g}$ & $\mathrm{ng} / \mathrm{g}$ & $\mathrm{ng} / \mathrm{g}$ & $\mathrm{ng} / \mathrm{g}$ & $\mathrm{ng} / \mathrm{g}$ & $\mathrm{ng} / \mathrm{g}$ & $\mathrm{ng} / \mathrm{g}$ \\
\hline MRL & - & - & 1.0 & 1.0 & - & 100 & - & - & - \\
\hline MDL & 30 & 37 & - & - & 24 & - & 26 & 30 & 32 \\
\hline Reprod & - & - & - & - & - & - & - & 21 & - \\
\hline Ash & ND & ND & ND & ND & ND & ND & ND & 100 & ND \\
\hline Bvtn & I & I & ND & ND & I & ND & I & I & I \\
\hline Bvtn-r & I & I & ND & ND & I & ND & I & I & I \\
\hline Bronson & ND & ND & ND & ND & ND & ND & ND & ND & ND \\
\hline Cedar & ND & ND & ND & ND & ND & ND & ND & 35 & ND \\
\hline Chicken & ND & ND & ND & ND & ND & ND & ND & ND & ND \\
\hline Dairy & ND & ND & ND & ND & ND & ND & ND & ND & ND \\
\hline FanDen & ND & ND & ND & ND & ND & ND & ND & 93 & ND \\
\hline FanDen-r & ND & ND & ND & ND & ND & ND & ND & 72 & ND \\
\hline Fan-92 & ND & ND & ND & ND & ND & ND & ND & ND & ND \\
\hline Fan-93a & ND & ND & ND & ND & ND & ND & ND & ND & ND \\
\hline Fan-93b & ND & ND & ND & ND & ND & ND & ND & 40 & ND \\
\hline Fan-93c & ND & ND & ND & ND & ND & ND & ND & ND & ND \\
\hline UpFan & ND & ND & ND & ND & ND & ND & ND & $23^{d}$ & ND \\
\hline Gales & ND & ND & ND & ND & ND & ND & ND & ND & ND \\
\hline McKay & ND & ND & ND & ND & ND & ND & ND & 94 & ND \\
\hline LoRock & ND & ND & ND & ND & ND & ND & ND & 35 & ND \\
\hline LoRock-a & ND & ND & ND & ND & ND & ND & ND & ND & ND \\
\hline LoRock-b & ND & ND & ND & ND & ND & ND & ND & ND & ND \\
\hline UpRock & ND & ND & ND & ND & ND & ND & ND & ND & ND \\
\hline UpTual & ND & ND & ND & ND & ND & ND & ND & ND & ND \\
\hline Tual-Els & ND & ND & ND & ND & ND & ND & ND & ND & ND \\
\hline
\end{tabular}


Appendix B. Bed sediment data—continued

[Abbreviations: mg/g, milligram per gram; $\mu \mathrm{g} / \mathrm{g}$, microgram per gram; ng/g, nanogram per gram; ND, not detected; I, interference; E, estimated value; —, no value]

\begin{tabular}{|c|c|c|c|c|c|c|c|c|c|}
\hline $\begin{array}{c}\text { Site } \\
\text { abbrev }\end{array}$ & $\begin{array}{c}\text { bis(2- } \\
\text { Chloroethoxy) } \\
\text { methane }\end{array}$ & $\begin{array}{c}\text { 4-Bromo- } \\
\text { phenyl- } \\
\text { phenylether }\end{array}$ & $\begin{array}{c}\text { 4-Chloro- } \\
\text { phenyl- } \\
\text { phenylether }\end{array}$ & $\begin{array}{l}\text { Dibenzo- } \\
\text { thiophene }\end{array}$ & $\begin{array}{l}\text { 2,4-Dinitro- } \\
\text { toluene }\end{array}$ & Isophorone & Nitrobenzene & $\begin{array}{l}\text { N-Nitroso- } \\
\text { diphenyl- } \\
\text { amine }\end{array}$ & $\begin{array}{l}\text { N-Nitroso- } \\
\text { di- } n \text {-propyl- } \\
\text { amine }\end{array}$ \\
\hline P-Code & 49401 & 49454 & 49455 & 49452 & 49395 & 49400 & 49444 & 49433 & 49431 \\
\hline Units & $\mathrm{ng} / \mathrm{g}$ & $\mathrm{ng} / \mathrm{g}$ & $\mathrm{ng} / \mathrm{g}$ & $\mathrm{ng} / \mathrm{g}$ & $\mathrm{ng} / \mathrm{g}$ & $\mathrm{ng} / \mathrm{g}$ & $\mathrm{ng} / \mathrm{g}$ & $\mathrm{ng} / \mathrm{n}$ & $\mathrm{ng} / \mathrm{g}$ \\
\hline MRL & - & - & - & - & - & - & - & - & - \\
\hline MDL & 34 & 29 & 30 & 28 & 29 & 27 & 31 & 27 & 28 \\
\hline Reprod & - & - & - & - & - & - & - & - & - \\
\hline Ash & ND & ND & ND & ND & ND & ND & ND & $13^{\mathrm{d}}$ & ND \\
\hline Bvtn & I & I & I & I & I & I & I & I & I \\
\hline Bvtn-r & I & I & I & I & I & I & I & I & I \\
\hline Bronson & ND & ND & ND & ND & ND & ND & ND & 28 & ND \\
\hline Cedar & ND & ND & ND & ND & ND & ND & ND & ND & ND \\
\hline Chicken & ND & ND & ND & ND & ND & ND & ND & ND & ND \\
\hline Dairy & ND & ND & ND & ND & ND & ND & ND & ND & ND \\
\hline FanDen & ND & ND & ND & ND & ND & ND & ND & ND & ND \\
\hline FanDen-r & ND & ND & ND & $27^{d}$ & ND & ND & ND & ND & ND \\
\hline Fan-92 & ND & ND & ND & $12^{d}$ & ND & ND & ND & ND & ND \\
\hline Fan-93a & ND & ND & ND & ND & ND & ND & ND & ND & ND \\
\hline Fan-93b & ND & ND & ND & ND & ND & ND & ND & ND & ND \\
\hline Fan-93c & ND & ND & ND & ND & ND & ND & ND & ND & ND \\
\hline UpFan & ND & ND & ND & $14^{\mathrm{d}}$ & ND & ND & ND & ND & ND \\
\hline Gales & ND & ND & ND & ND & ND & ND & ND & ND & ND \\
\hline McKay & ND & ND & ND & 31 & ND & ND & ND & ND & ND \\
\hline LoRock & ND & ND & ND & ND & ND & ND & ND & ND & ND \\
\hline LoRock-a & ND & ND & ND & ND & ND & ND & ND & ND & ND \\
\hline LoRock-b & ND & ND & ND & ND & ND & ND & ND & ND & ND \\
\hline UpRock & ND & ND & ND & $27^{\mathrm{d}}$ & ND & ND & ND & ND & ND \\
\hline UpTual & ND & ND & ND & ND & ND & ND & ND & ND & ND \\
\hline Tual-Els & ND & ND & ND & ND & ND & ND & ND & ND & ND \\
\hline
\end{tabular}


Appendix B. Bed sediment data—continued

[Abbreviations: mg/g, milligram per gram; $\mu \mathrm{g} / \mathrm{g}$, microgram per gram; ng/g, nanogram per gram; ND, not detected; I, interference; E, estimated value; —, no value]

\begin{tabular}{|c|c|c|c|c|c|c|}
\hline \multirow{2}{*}{$\begin{array}{c}\text { Site } \\
\text { abbrev }\end{array}$} & \multicolumn{6}{|c|}{ Surrogate Compounds } \\
\hline & 3,5-Dichlorobiphenyl & $\alpha-\mathrm{HCH}-d_{6}$ & PCB-204 & 2-Fluorobiphenyl & Nitrobenzene- $d_{5}$ & Terphenyl- $d_{14}$ \\
\hline P-Code & 49277 & 49275 & 49276 & 49279 & 49280 & 49278 \\
\hline Units & percent recovery & percent recovery & percent recovery & percent recovery & percent recovery & percent recovery \\
\hline MRL & - & - & - & - & - & - \\
\hline MDL & - & - & - & - & - & - \\
\hline Reprod & 4 & 5 & 6 & 14 & 29 & 10 \\
\hline Ash & 64 & 70 & 73 & 50 & 59 & 58 \\
\hline Bvtn & 58 & 72 & 48 & 120 & 65 & - \\
\hline Bvtn-r & 57 & 70 & 47 & 120 & 36 & - \\
\hline Bronson & 59 & 85 & 57 & 69 & 68 & 91 \\
\hline Cedar & 61 & 61 & 69 & 71 & 72 & 99 \\
\hline Chicken & 59 & 69 & 66 & 54 & 64 & 76 \\
\hline Dairy & 65 & 74 & 58 & 59 & 79 & 93 \\
\hline FanDen & 66 & 79 & 67 & 66 & 79 & - \\
\hline FanDen-r & 62 & 75 & 61 & 51 & 80 & - \\
\hline Fan-92 & 59 & 40 & 46 & 29 & 30 & 38 \\
\hline Fan-93a & 48 & 55 & 45 & 89 & 82 & 79 \\
\hline Fan-93b & 58 & 63 & 54 & 92 & 84 & 78 \\
\hline Fan-93c & 60 & 65 & 62 & 53 & 41 & 76 \\
\hline UpFan & 66 & 77 & 78 & 39 & 43 & 54 \\
\hline Gales & 52 & 73 & 82 & 36 & 39 & 58 \\
\hline McKay & 66 & 74 & 85 & 66 & 78 & 89 \\
\hline LoRock & 65 & 74 & 75 & 63 & 77 & 96 \\
\hline LoRock-a & 64 & 76 & 74 & 65 & 69 & 100 \\
\hline LoRock-b & 67 & 71 & 78 & 63 & 65 & 90 \\
\hline UpRock & 60 & 69 & 60 & 60 & 72 & 93 \\
\hline UpTual & 52 & 70 & 68 & 47 & 53 & 58 \\
\hline Tual-Els & 71 & 75 & 76 & 66 & 70 & 89 \\
\hline
\end{tabular}




\section{Appendix C. Qualitative description of fish occurence and abundance}

[Descriptions based on field notes made while collecting sculpin for tissue analysis. Sites were not sampled for fish assemblage information. Length of reach sampled varied among sites. "Abundant" means the species was seen in large numbers throughout the section of stream sampled; "common" means the species was observed frequently to occasionally, but not in large numbers; "present" means that at least one individual was observed.]

\begin{tabular}{cc}
\hline $\begin{array}{c}\text { Site } \\
\text { abbrev }\end{array}$ & Notes \\
\hline
\end{tabular}

Bvtn Beaverton Creek at Cedar Hills Blvd Few fish were present. Only 4 sculpin were collected. Three-spine stickleback were common. Redside shiner were present. Approximately half of the stickleback and shiners caught had visible signs of external abnormalities, primarily white tumors.

Bronson Bronson Creek at Walker Road

Cedar Cedar Mill Creek at Jenkins Rd

Dairy Dairy Creek at Susbauer Road

FanDen Fanno Creek near Denny Road

FanDen-r1 ...

FanDen-r2 ...

Fan-92 Fanno Creek at Durham, OR

Fan-93 ...

Fan-93-r1 ...

Fan-93-r2 ...

Fan-96

UpFan Upper Fanno Creek at Nicol Road

Gales-92 Gales Creek near Glenwood, OR

Gales-96 $\cdots$
Few fish. Only a couple of reticulate sculpin were collected (not enough for a complete sample - tissue was sent for organochlorine analysis, but not for element analysis). The most common fish was largemouth bass, redside shiners were present.

High abundance of reticulate sculpin. Few, if any, other fish were observed because sculpin were so common that only a short section of river was sampled.

Sculpin were abundant and redside shiners were present. Stream was dominated by reticulate sculpin.

Few fish overall. Even sculpin were not abundant.
High abundance of fish, $90 \%$ of which were reticulate sculpin. Redside shiner, speckled dace were common; largescale sucker, cutthroat trout, western brook lamprey, gambusia, and bluegill were present. Low occurrence of external fish abnormalities.

UpRock Upper Rock Creek at Baseline Road Few fish overall. Sculpin were common. Only a couple of other fish were seen. 
Appendix D. Fish tissue data

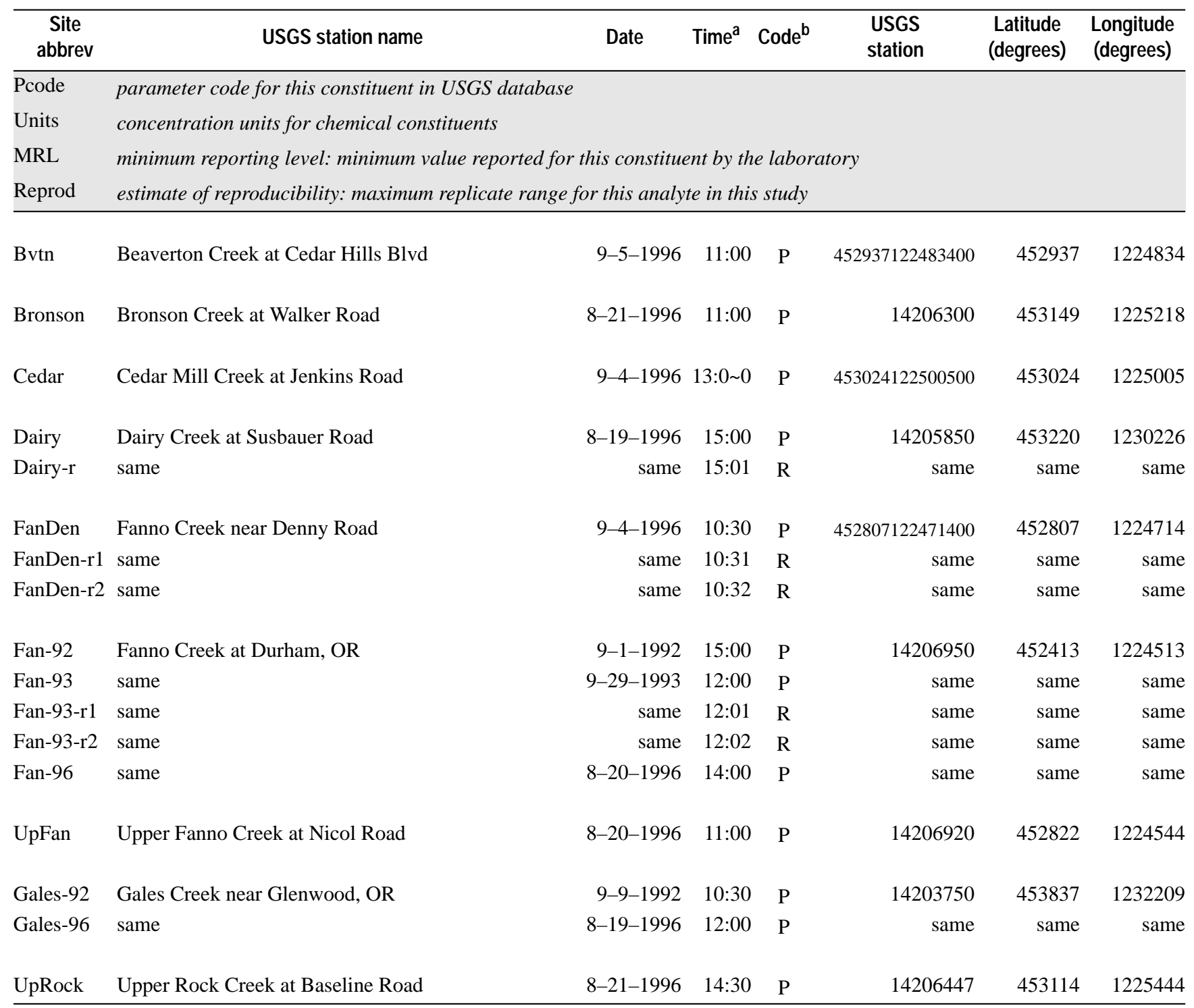

a-Time is a sample label and was not the exact sampling time. Together, USGS Ststion, date and time, uniquely identify a sample.

$\mathrm{b}-$ Code for sample type: $\mathrm{P}=$ primary sample; $\mathrm{R}=$ replicate sample 
Appendix D. Fish tissue data—continued

[Abbreviations: $\mu \mathrm{g} / \mathrm{g}$, microgram per gram; ng/g, nanogram per gram; dry, on a dry-weight basis; wet, on a wet-weight basis; ND, not detected; I, interference; E, estimated value; - , no value]

\begin{tabular}{|c|c|c|c|c|c|c|c|c|}
\hline \multirow{2}{*}{$\begin{array}{c}\text { Site } \\
\text { abbrev }\end{array}$} & \multicolumn{2}{|c|}{ Number of fish in sample } & \multirow{2}{*}{ Moisture } & \multirow{2}{*}{ Lipid } & \multirow{2}{*}{ Aluminum } & \multirow{2}{*}{ Iron } & \multirow{2}{*}{ Antimony } & \multirow{2}{*}{ Arsenic } \\
\hline & elements & organics & & & & & & \\
\hline P-Code & - & - & 49273 & 49289 & 49237 & 49242 & 49246 & 49247 \\
\hline Units & number & number & percent & percent & $\mu \mathrm{g} / \mathrm{g}$ (dry) & $\mu \mathrm{g} / \mathrm{g}$ (dry) & $\mu \mathrm{g} / \mathrm{g}$ (dry) & $\mu \mathrm{g} / \mathrm{g}$ (dry) \\
\hline MRL & - & - & - & - & 1.0 & 1.0 & 0.2 & 0.2 \\
\hline Reprod & - & - & 1.2 & 2.7 & 71.2 & 135 & - & 0.1 \\
\hline Bvtn & 0 & 4 & - & 4.0 & - & - & - & - \\
\hline Bronson & 0 & 7 & - & 4.3 & - & - & - & - \\
\hline Cedar & 10 & 10 & 76.0 & 3.4 & 18.8 & 66.3 & ND & 0.4 \\
\hline Dairy & 10 & 10 & 77.0 & 3.0 & 20.4 & 61.3 & ND & ND \\
\hline Dairy-r & 0 & 10 & - & 3.6 & - & - & - & - \\
\hline FanDen & 10 & 10 & 77.5 & 3.0 & 47.6 & 134 & ND & 0.2 \\
\hline FanDen-r1 & 10 & 10 & 77.6 & 2.8 & 15.4 & 57.4 & ND & ND \\
\hline FanDen-r2 & 10 & 10 & 78.4 & 3.5 & 27.8 & 97.9 & ND & ND \\
\hline Fan-92 & 10 & 10 & 76.8 & 5.0 & 44.2 & 110 & ND & 0.4 \\
\hline Fan-93 & 10 & 10 & 78.0 & 3.9 & 181 & 279 & ND & 0.3 \\
\hline Fan-93-r1 & 10 & 10 & 76.9 & 3.7 & 123 & 183 & ND & 0.3 \\
\hline Fan-93-r2 & 10 & 10 & 76.8 & 6.4 & 127 & 237 & ND & 0.4 \\
\hline Fan-96 & 10 & 10 & 77.0 & 3.3 & 18.9 & 80.2 & ND & 0.3 \\
\hline UpFan & 10 & 10 & 75.9 & 6.5 & 34.8 & 84.3 & ND & 0.2 \\
\hline Gales-92 & 10 & 10 & 76.4 & 2.6 & 90.6 & 216 & ND & ND \\
\hline Gales-96 & 12 & 15 & 76.6 & 2.6 & 19.4 & 81.1 & ND & ND \\
\hline UpRock & 10 & 10 & 76.6 & 3.1 & 5.1 & 56.1 & ND & 0.2 \\
\hline
\end{tabular}


Appendix D. Fish tissue data-continued

[Abbreviations: $\mu \mathrm{g} / \mathrm{g}$, microgram per gram; ng/g, nanogram per gram; dry, on a dry-weight basis; wet, on a wet-weight basis; ND, not detected; I, interference; E, estimated value; — , no value]

\begin{tabular}{|c|c|c|c|c|c|c|c|c|c|}
\hline $\begin{array}{c}\text { Site } \\
\text { abbrev }\end{array}$ & Barium & Beryllium & Boron & Cadmium & Chromium & Cobalt & Copper & Lead & Manganese \\
\hline P-Code & 49238 & 49248 & 49239 & 49249 & 49240 & 49250 & 49241 & 49251 & 49243 \\
\hline Units & $\mu \mathrm{g} / \mathrm{g}$ (dry) & $\mu \mathrm{g} / \mathrm{g}$ (dry) & $\mu \mathrm{g} / \mathrm{g}$ (dry) & $\mu \mathrm{g} / \mathrm{g}$ (dry) & $\mu \mathrm{g} / \mathrm{g}$ (dry) & $\mu \mathrm{g} / \mathrm{g}$ (dry) & $\mu \mathrm{g} / \mathrm{g}$ (dry) & $\mu \mathrm{g} / \mathrm{g}$ (dry) & $\mu \mathrm{g} / \mathrm{g}$ (dry) \\
\hline MRL & 0.1 & 0.2 & 0.2 & 0.2 & 0.5 & 0.2 & 0.5 & 0.2 & 0.1 \\
\hline Reprod & 3.4 & - & 8.6 & - & 0.6 & 0.1 & 1.5 & 0.4 & 38.1 \\
\hline Bvtn & - & - & - & - & - & - & - & - & - \\
\hline Bronson & - & - & - & - & - & - & - & - & - \\
\hline Cedar & 11.0 & ND & 1.0 & ND & 1.9 & 0.2 & 2.0 & 0.2 & 17.3 \\
\hline Dairy & 22.4 & ND & 0.3 & ND & 1.9 & 0.3 & 2.7 & ND & 22.2 \\
\hline Dairy-r & - & - & - & - & - & - & - & - & - \\
\hline FanDen & 11.0 & ND & 1.4 & ND & 1.9 & 0.3 & 2.9 & 0.5 & 36.6 \\
\hline FanDen-r1 & 10.1 & ND & 0.8 & ND & 1.6 & ND & 1.7 & 0.5 & 23.9 \\
\hline FanDen-r2 & 13.5 & ND & 2.4 & ND & 2.2 & 0.3 & 3.2 & 0.6 & 50.0 \\
\hline Fan-92 & 9.8 & ND & 2.5 & ND & 1.6 & 0.6 & 3.8 & 0.7 & 51.1 \\
\hline Fan-93 & 11.0 & ND & 2.8 & ND & 1.7 & 0.6 & 3.3 & 0.9 & 78.1 \\
\hline Fan-93-r1 & 10.9 & ND & 9.4 & ND & 1.6 & 0.5 & 4.0 & 0.5 & 49.9 \\
\hline Fan-93-r2 & 10.1 & ND & 0.8 & ND & 1.5 & 0.6 & 3.7 & 0.6 & 88.0 \\
\hline Fan-96 & 9.6 & ND & 3.5 & ND & 1.8 & 0.3 & 3.6 & 0.8 & 27.1 \\
\hline UpFan & 9.4 & ND & 0.9 & ND & 1.6 & 0.3 & 2.0 & 0.3 & 34.9 \\
\hline Gales-92 & 2.4 & ND & 0.9 & ND & 2.0 & 0.6 & 1.8 & ND & 8.3 \\
\hline Gales-96 & 2.0 & ND & 0.5 & ND & 2.0 & 0.5 & 2.6 & ND & 9.7 \\
\hline UpRock & 12.6 & ND & 1.5 & ND & 1.9 & 0.3 & 2.9 & ND & 27.9 \\
\hline
\end{tabular}


Appendix D. Fish tissue data—continued

[Abbreviations: $\mu \mathrm{g} / \mathrm{g}$, microgram per gram; ng/g, nanogram per gram; dry, on a dry-weight basis; wet, on a wet-weight basis; ND, not detected; I, interference; E, estimated value; - , no value]

\begin{tabular}{|c|c|c|c|c|c|c|c|c|c|}
\hline $\begin{array}{c}\text { Site } \\
\text { abbrev }\end{array}$ & Mercury & Molybdenum & Nickel & Selenium & Silver & Strontium & Uranium & Vanadium & Zinc \\
\hline P-Code & 49258 & 49252 & 49253 & 49254 & 49255 & 49244 & 49257 & 49465 & 49245 \\
\hline Units & $\mu \mathrm{g} / \mathrm{g}$ (dry) & $\mu \mathrm{g} / \mathrm{g}$ (dry) & $\mu \mathrm{g} / \mathrm{g}$ (dry) & $\mu \mathrm{g} / \mathrm{g}$ (dry) & $\mu \mathrm{g} / \mathrm{g}$ (dry) & $\mu \mathrm{g} / \mathrm{g}$ (dry) & $\mu \mathrm{g} / \mathrm{g}$ (dry) & $\mu \mathrm{g} / \mathrm{g}$ (dry) & $\mu \mathrm{g} / \mathrm{g}$ (dry) \\
\hline MRL & 0.02 & 0.2 & 0.2 & 0.1 & 0.2 & 0.1 & 0.2 & 0.1 & 0.5 \\
\hline Reprod & 0.46 & - & 3.3 & 0.4 & - & 26.5 & - & 0.7 & 26 \\
\hline Bvtn & - & - & - & - & - & - & - & - & - \\
\hline Bronson & - & - & - & - & - & - & - & - & - \\
\hline Cedar & 0.33 & ND & 0.4 & 1.4 & ND & 80.9 & ND & 1.2 & 84.3 \\
\hline Dairy & 0.32 & ND & 0.4 & 1.9 & ND & 121 & ND & 1.0 & 83.8 \\
\hline Dairy-r & - & - & - & - & - & - & - & - & - \\
\hline FanDen & 0.95 & ND & 0.6 & 1.8 & ND & 102 & ND & 1.5 & 78.4 \\
\hline FanDen-r1 & 1.0 & ND & ND & 1.8 & ND & 105 & ND & 1.2 & 77 \\
\hline FanDen-r2 & 0.54 & ND & 0.5 & 2.2 & ND & 118 & ND & 1.3 & 103 \\
\hline Fan-92 & 0.30 & ND & 3.3 & $\mathrm{ND}(1.4)^{\mathrm{c}}$ & ND & 82.6 & ND & 1.7 & 99.0 \\
\hline Fan-93 & 0.10 & ND & 1.5 & 1.4 & ND & 70.2 & ND & 2.4 & 98.4 \\
\hline Fan-93-r1 & 0.20 & ND & 1.4 & $\mathrm{ND}(1.3)^{\mathrm{c}}$ & ND & 80.4 & ND & 1.7 & 99.3 \\
\hline Fan-93-r2 & $\mathrm{ND}(0.10)^{\mathrm{c}}$ & 0.5 & 1.8 & $\mathrm{ND}(1.3)^{\mathrm{c}}$ & ND & 65.3 & ND & 2.0 & 89.5 \\
\hline Fan-96 & 0.35 & ND & 0.6 & 1.6 & ND & 86.2 & ND & 1.2 & 98.1 \\
\hline UpFan & 0.25 & ND & 0.5 & 2.0 & ND & 89.8 & ND & 0.8 & 62.9 \\
\hline Gales-92 & $\mathrm{ND}(0.10)^{\mathrm{c}}$ & ND & 3.7 & $\mathrm{ND}(1.1)^{\mathrm{c}}$ & ND & 117 & ND & 1.3 & 110 \\
\hline Gales-96 & $\mathrm{ND}(0.03)^{\mathrm{c}}$ & ND & 0.4 & 1.1 & ND & 90.5 & ND & 0.6 & 91.3 \\
\hline UpRock & 0.86 & ND & 0.5 & 2.5 & ND & 77.2 & ND & 1.2 & 102 \\
\hline
\end{tabular}


Appendix D. Fish tissue data—continued

[Abbreviations: $\mu \mathrm{g} / \mathrm{g}$, microgram per gram; ng/g, nanogram per gram; dry, on a dry-weight basis; wet, on a wet-weight basis; ND, not detected; I, interference; E, estimated value; - , no value]

\begin{tabular}{|c|c|c|c|c|c|c|c|c|c|}
\hline $\begin{array}{c}\text { Site } \\
\text { abbrev }\end{array}$ & Adrin & cis-Chlordane & $\begin{array}{c}\text { trans- } \\
\text { Chlordane }\end{array}$ & o,p'-DDD & $p, p^{\prime}-\mathrm{DDD}$ & $0, p^{\prime}-\mathrm{DDE}$ & $p, p^{\prime}-\mathrm{DDE}$ & o,p'-DDT & $p, p^{\prime}-\mathrm{DDT}$ \\
\hline P-Code & 49353 & 49380 & 49379 & 49374 & 49375 & 49373 & 49372 & 49377 & 49376 \\
\hline Units & ng/g (wet) & ng/g (wet) & ng/g (wet) & ng/g (wet) & ng/g (wet) & ng/g (wet) & ng/g (wet) & ng/g (wet) & ng/g (wet) \\
\hline MRL & 5.0 & 5.0 & 5.0 & 5.0 & 5.0 & 5.0 & 5.0 & 5.0 & 5.0 \\
\hline Reprod & - & 6 & 23 & - & 2.2 & - & 6 & - & 2.0 \\
\hline Bvtn & ND & 27 & 13 & ND & E24.0 & ND & 20 & ND & 5.0 \\
\hline Bronson & ND & 12 & ND & ND & $\mathrm{ND}$ & ND & 7 & ND & ND \\
\hline Cedar & ND & 16 & 6.6 & ND & ND & ND & 16 & ND & ND \\
\hline Dairy & ND & ND & ND & ND & ND & ND & 14 & ND & E7.8 \\
\hline Dairy-r & ND & 7.2 & ND & ND & ND & ND & 16 & ND & 9.4 \\
\hline FanDen & ND & 76 & 19 & ND & E6.0 & ND & 14 & ND & 5.8 \\
\hline FanDen-r1 & ND & 82 & 28 & ND & E8.2 & $\mathrm{ND}(7)^{\mathrm{c}}$ & 14 & ND & 7.4 \\
\hline FanDen-r2 & ND & 78 & $\mathrm{ND}$ & ND & E6.2 & ND & 12 & ND & 6.4 \\
\hline Fan-92 & ND & ND & 9.1 & ND & ND & ND & 9 & ND & 5.6 \\
\hline Fan-93 & ND & 14 & 6 & ND & ND & ND & 18 & ND & 5.7 \\
\hline Fan-93-r1 & ND & 15 & 8.4 & ND & ND & ND & 19 & ND & 7.4 \\
\hline Fan-93-r2 & ND & 15 & 6 & ND & ND & ND & 13 & ND & 5.4 \\
\hline Fan-96 & ND & 21 & 11 & ND & ND & ND & 18 & ND & E8.6 \\
\hline UpFan & ND & 84 & 25 & ND & 10.0 & ND & 21 & ND & ND \\
\hline Gales-92 & ND & ND & ND & ND & $\mathrm{ND}$ & ND & ND & ND & ND \\
\hline Gales-96 & ND & ND & ND & ND & $\mathrm{ND}$ & ND & $\mathrm{ND}$ & ND & ND \\
\hline UpRock & ND & 8.3 & ND & ND & E5.3 & ND & 10 & ND & ND \\
\hline
\end{tabular}


Appendix D. Fish tissue data—continued

[Abbreviations: $\mu \mathrm{g} / \mathrm{g}$, microgram per gram; ng/g, nanogram per gram; dry, on a dry-weight basis; wet, on a wet-weight basis; ND, not detected; I, interference; E, estimated value; - , no value]

\begin{tabular}{|c|c|c|c|c|c|c|c|c|c|}
\hline $\begin{array}{c}\text { Site } \\
\text { abbrev }\end{array}$ & Dacthal & Dieldrin & Endrin & $\alpha-\mathrm{HCH}$ & $\beta-\mathrm{HCH}$ & $\delta-\mathrm{HCH}$ & $\gamma-\mathrm{HCH}$ & Heptachlor & $\begin{array}{l}\text { Heptachlor } \\
\text { epoxide }\end{array}$ \\
\hline P-Code & 49378 & 49371 & 49370 & 49366 & 49365 & 49364 & 49363 & 49369 & 49368 \\
\hline Units & ng/g (wet) & ng/g (wet) & ng/g (wet) & ng/g (wet) & ng/g (wet) & ng/g (wet) & ng/g (wet) & ng/g (wet) & ng/g (wet) \\
\hline MRL & 5.0 & 5.0 & 5.0 & 5.0 & 5.0 & 5.0 & 5.0 & 5.0 & 5.0 \\
\hline Reprod & - & 12 & - & - & - & - & - & - & - \\
\hline Bvtn & ND & 20 & $\mathrm{ND}(12)^{\mathrm{c}}$ & ND & ND & ND & ND & ND & E12 \\
\hline Bronson & ND & 9.3 & $\mathrm{ND}(26)^{\mathrm{c}}$ & ND & ND & ND & ND & ND & ND \\
\hline Cedar & ND & 13 & $\operatorname{ND}(7)^{\mathrm{c}}$ & ND & ND & ND & ND & ND & E6.4 \\
\hline Dairy & ND & 23 & ND & ND & ND & ND & ND & ND & ND \\
\hline Dairy-r & ND & 15 & $\mathrm{ND}(18)^{\mathrm{c}}$ & ND & ND & ND & ND & ND & ND \\
\hline FanDen & ND & 20 & $\mathrm{ND}(6)^{\mathrm{c}}$ & ND & ND & ND & ND & ND & I \\
\hline FanDen-r1 & ND & 32 & $\mathrm{ND}(13)^{\mathrm{c}}$ & ND & ND & ND & ND & ND & I \\
\hline FanDen-r2 & ND & 28 & $\mathrm{ND}(11)^{\mathrm{c}}$ & ND & ND & ND & ND & ND & I \\
\hline Fan-92 & ND & 12 & ND & ND & ND & ND & ND & ND & ND \\
\hline Fan-93 & ND & 15 & ND & ND & ND & ND & ND & ND & ND \\
\hline Fan-93-r1 & ND & 19 & ND & ND & ND & ND & ND & ND & ND \\
\hline Fan-93-r2 & ND & 14 & ND & ND & ND & ND & ND & ND & ND \\
\hline Fan-96 & ND & 14 & ND & ND & ND & ND & ND & ND & 11 \\
\hline UpFan & ND & 86 & ND & E6.6 & ND & ND & ND & ND & 14 \\
\hline Gales-92 & ND & ND & ND & ND & ND & ND & ND & ND & ND \\
\hline Gales-96 & ND & ND & $\operatorname{ND}(6)^{\mathrm{c}}$ & ND & ND & ND & ND & ND & ND \\
\hline UpRock & ND & 6 & $\operatorname{ND}(6)^{\mathrm{c}}$ & ND & ND & ND & ND & ND & ND \\
\hline
\end{tabular}


Appendix D. Fish tissue data—continued

[Abbreviations: $\mu \mathrm{g} / \mathrm{g}$, microgram per gram; ng/g, nanogram per gram; dry, on a dry-weight basis; wet, on a wet-weight basis; ND, not detected; I, interference; E, estimated value; - , no value]

\begin{tabular}{|c|c|c|c|c|c|c|c|c|c|c|}
\hline $\begin{array}{c}\text { Site } \\
\text { abbrev }\end{array}$ & $\begin{array}{l}\text { o,p-Meth- } \\
\text { oxychlor }\end{array}$ & $\begin{array}{l}\text { p,p-Meth- } \\
\text { oxychlor }\end{array}$ & Mirex & $\begin{array}{c}\text { cis- } \\
\text { Nonachlor }\end{array}$ & $\begin{array}{c}\text { trans- } \\
\text { Nonachlor }\end{array}$ & $\begin{array}{l}\text { Oxychlor- } \\
\text { dane }\end{array}$ & Toxaphene & $\begin{array}{l}\text { Hexachloro- } \\
\text { benzene }\end{array}$ & $\begin{array}{l}\text { Pentachloro- } \\
\text { anisole }\end{array}$ & total PCB \\
\hline P-Code & 49362 & 49361 & 49360 & 49359 & 49358 & 49357 & 49355 & 49367 & 49356 & 49354 \\
\hline Units & ng/g (wet) & ng/g (wet) & ng/g (wet) & ng/g (wet) & ng/g (wet) & ng/g (wet) & ng/g (wet) & ng/g (wet) & ng/g (wet) & ng/g (wet) \\
\hline MRL & 5.0 & 5.0 & 5.0 & 5.0 & 5.0 & 5.0 & 200 & 5.0 & 5.0 & 50 \\
\hline Reprod & - & - & - & 6 & 7 & - & - & - & 3.1 & 73 \\
\hline Bvtn & ND & ND & ND & 7.8 & 29 & E10 & ND & ND & ND & 120 \\
\hline Bronson & ND & ND & ND & ND & 13 & ND & ND & ND & ND & 54 \\
\hline Cedar & ND & ND & ND & ND & 18 & E8.9 & ND & ND & 7.4 & 69 \\
\hline Dairy & ND & ND & ND & ND & 7.0 & ND & ND & ND & 6.7 & ND \\
\hline Dairy-r & ND & ND & ND & ND & 9.6 & ND & ND & ND & 8.4 & ND \\
\hline FanDen & ND & ND & ND & E12 & 73 & I & ND & ND & 5.8 & 96 \\
\hline FanDen-r1 & ND & ND & ND & E18 & 74 & I & ND & ND & 8.9 & 150 \\
\hline FanDen-r2 & ND & ND & ND & E15 & 67 & I & ND & ND & 7.4 & 77 \\
\hline Fan-92 & ND & ND & ND & 9.2 & 27 & ND & ND & ND & 5.0 & 200 \\
\hline Fan-93 & ND & ND & ND & 7.2 & 18 & ND & ND & ND & ND & 380 \\
\hline Fan-93-r1 & ND & ND & ND & 6.3 & 20 & ND & ND & ND & ND & 440 \\
\hline Fan-93-r2 & ND & ND & ND & 6.5 & 20 & ND & ND & ND & ND & 440 \\
\hline Fan-96 & ND & ND & ND & ND & 17 & 7.8 & ND & ND & ND & 81 \\
\hline UpFan & ND & ND & ND & 14 & 74 & 35 & ND & ND & 22 & 110 \\
\hline Gales-92 & ND & ND & ND & ND & ND & ND & ND & ND & ND & ND \\
\hline Gales-96 & ND & ND & ND & ND & ND & ND & ND & ND & $\mathrm{ND}$ & ND \\
\hline UpRock & ND & ND & ND & ND & 12 & ND & ND & ND & 12 & ND \\
\hline
\end{tabular}


Appendix D. Fish tissue data-continued

[Abbreviations: $\mu \mathrm{g} / \mathrm{g}$, microgram per gram; ng/g, nanogram per gram; dry, on a dry-weight basis; wet, on a wet-weight basis; ND, not detected; I, interference; E, estimated value; - - no value]

\begin{tabular}{|c|c|c|}
\hline \multirow{2}{*}{$\begin{array}{c}\text { Site } \\
\text { abbrev }\end{array}$} & \multicolumn{2}{|c|}{ Surrogate compounds } \\
\hline & 3,5-Dichlorobiphenyl & $\alpha-\mathrm{HCH}-d_{6}$ \\
\hline P-Code & 49264 & 49261 \\
\hline Units & percent recovery & percent recovery \\
\hline MRL & - & - \\
\hline Reprod & 35 & 14 \\
\hline Bvtn & 54 & 85 \\
\hline Bronson & 57 & 0 \\
\hline Cedar & 51 & 95 \\
\hline Dairy & 70 & 80 \\
\hline Dairy-r & 45 & 82 \\
\hline FanDen & 50 & 77 \\
\hline FanDen-r1 & 61 & 93 \\
\hline FanDen-r2 & 52 & 91 \\
\hline Fan-92 & 0 & - \\
\hline Fan-93 & 0 & 0 \\
\hline Fan-93-r1 & 0 & 0 \\
\hline Fan-93-r2 & 0 & 0 \\
\hline Fan-96 & 66 & 82 \\
\hline UpFan & 75 & 94 \\
\hline Gales-92 & 0 & - \\
\hline Gales-96 & 59 & 86 \\
\hline UpRock & 57 & 92 \\
\hline
\end{tabular}

